VIVIAN LIKA HASHIMOTO

\title{
CLONAGEM E EXPRESSÃO GÊNICA DE ANTÍGENOS CANDIDATOS VACINAIS CONTRA LEPTOSPIROSE
}

Tese apresentada ao Programa de Pós-Graduação Interunidades em Biotecnologia USP/Instituto Butantan/IPT para a obtenção do Título de Doutor em Biotecnologia. 


\section{CLONAGEM E EXPRESSÃO GÊNICA DE ANTÍGENOS CANDIDATOS VACINAIS CONTRA LEPTOSPIROSE}

Tese apresentada ao Programa de Pós-Graduação Interunidades em Biotecnologia USP/Instituto Butantan/IPT para a obtenção do Título de Doutor em Biotecnologia.

Área de concentração:

Biotecnologia

Orientador: Dr. Paulo Lee Ho

Versão original 
DADOS DE CATALOGAÇÃO NA PUBLICAÇÃO (CIP)

Serviço de Biblioteca e Informação Biomédica do

Instituto de Ciências Biomédicas da Universidade de São Paulo

(c) reprodução total

Hashimoto, Vivian Lika.

Clonagem e expressão gênica de antígenos candidatos vacinais contra leptospirose / Vivian Lika Hashimoto. -- São Paulo, 2012.

Orientador: Prof ${ }^{\circ}$ Dr. Paulo Lee Ho.

Tese (Doutorado) - Universidade de São Paulo. Instituto de Ciências Biomédicas. Programa de Pós-Graduação Interunidades em Biotecnologia USP/IPT/Instituto Butantan. Área de concentração: Biotecnologia. Linha de pesquisa: Vacinologia, proteínas recombinantes, leptospirose.

Versão do título para o inglês: Cloning and gene expression of antigens candidate against leptospirosis.

Descritores: 1. Vacinas 2. Proteínas recombinantes 3. Leptospirose I. Ho, Profo Dr. Paulo Lee II. Universidade de São Paulo. Instituto de Ciências Biomédicas. Programa de Pós-Graduação Interunidades em Biotecnologia USP/IPT/Instituto Butantan III. Título. 
Candidato(a):

Título da Tese:
Vivian Lika Hashimoto.

Clonagem e expressão gênica de antígenos candidatos vacinais contra leptospirose.

Orientador(a): $\quad \operatorname{Prof}^{\circ}$ Dr. Paulo Lee Ho.

A Comissão Julgadora dos trabalhos de Defesa da Tese de Doutorado, em sessão pública realizada a considerou
( ) Aprovado(a)
( ) Reprovado(a)

\begin{tabular}{|c|c|}
\hline Examinador(a): & $\begin{array}{l}\text { Assinatura: } \\
\text { Nome: ........ } \\
\text { Instituição: }\end{array}$ \\
\hline Examinador(a): & $\begin{array}{l}\text { Assinatura: } \\
\text { Nome: ........ } \\
\text { Instituição: . }\end{array}$ \\
\hline Examinador(a) & $\begin{array}{l}\text { Assinatura: } \\
\text { Nome: ........ } \\
\text { Instituição: }\end{array}$ \\
\hline Examinador(a): & $\begin{array}{l}\text { Assinatura: } \\
\text { Nome: ........ } \\
\text { Instituição: }\end{array}$ \\
\hline Presidente: & $\begin{array}{l}\text { Assinatura: } \\
\text { Nome: ........ } \\
\text { Instituição: }\end{array}$ \\
\hline
\end{tabular}




\section{CERTIFICADO}

Certificamos que o Protocolo para uso de animais em experimentação $n^{\circ} 256 / 06$, sobre o projeto intitulado "Desenvolvimento de vacinas contra a leptospirose", sob a responsabilidade de Paulo Lee Ho está de acordo com os Princípios Éticos na Experimentação Animal adotado pelo Colégio Brasileiro (COBEA) e foi aprovado pela COMISSÃO DE ÉTICA NO USO DE ANIMAIS DO INSTITUTO BUTANTAN (CEUAIB) em reunião de 14/03/2006.

São Paulo, 17 de março de 2006.

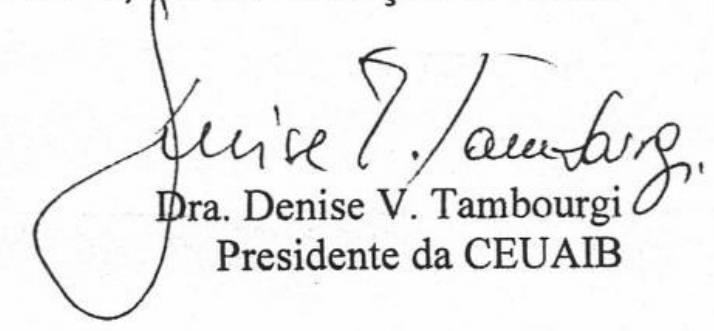

De acordo:

Dr. Otávio edo Mercadante

Diretor do Instituto Butantan 
Aos meus pais Neide e Mineo, que me impulsionaram a buscar a vida nova a cada dia, meus agradecimentos por terem aceitado se privar de minha companhia pelos estudos, concedendo a mim a oportunidade de me realizar ainda mais 


\section{AGRADECIMENTOS}

Ao meu orientador, Dr. Paulo Lee Ho pela paciência e confiança depositada em mim para a realização deste projeto de pesquisa.

Aos pesquisadores do Instituto Butantan, Dra. Patrícia Estima Antonia Abreu, Dr. Eneas de Carvalho e Dra. Elizabeth Cheng pelas discussões, dicas e pela colaboração em alguns experimentos.

Ao professor Dr. Silvio A. Vasconcellos, Ms. Amane P. Gonçales, Zenáide M. de Morais e Gisele do Laboratório de Zoonoses da Faculdade de Medicina Veterinária da USP pela colaboração com as culturas de leptospiras e ensaios de imunoproteção em hamsters.

À professora Dra. Eliete C. Romero do Instituto Adolfo Lutz pela colaboração com soros de pacientes diagnosticados com leptospirose.

À Dra. Erika Nakajima do Laboratório de Biotecnologia Molecular III pela colaboração com experimentos, pelas discussões científicas e não cientificas e, principalmente, pela amizade sincera. Obrigada Cabecinha!

À Dra. Elisabeth Angélica Martins e seu grupo de pesquisa por serem gentis, prestativos e principalmente pelo convívio, muito obrigada!

À Daniela, Cláudia, Erika, Roberta, Patt, Luciana L., Patrícia, Regiane, Luciane, Juliano e Henrique, por todas as risadas que demos juntos e, principalmente, pela amizade sincera nos momentos em que mais precisei.

Aos amigos, colegas e técnicos do laboratório de Biotecnologia Molecular I, meu muitíssimo obrigado pela paciência e convivência.

Aos professores que contribuíram para a minha formação.

A todos aquele que ajudaram direta ou indiretamente na elaboração deste trabalho, mas que por esquecimento ou desatenção não foram por mim citados nesta página, o meu muito obrigado.

À Fapesp, CNPq e à Fundação Butantan, pelo auxílio financeiro sem o qual seria impossível a realização deste projeto.

Um especial agradecimento aos meus pais e familiares pelo amor e apoio incondicional, compreensão e principalmente ao meu avô "Di" in memorium por ser minha maior fonte de inspiração. 
"Nem sempre são os caminhos conhecidos; nem sempre são os méritos exaltados; nem sempre são as críticas justificadas; mas mesmo assim, sempre vale a pena." (XXXIX Biomed UNESP-Botucatu, 2006) 


\section{RESUMO}

Hashimoto V.L. Clonagem e expressão gênica de antígenos candidatos vacinais contra leptospirose. [Tese (Doutorado em Biotecnologia)] - São Paulo - Instituto de Ciências Biomédicas da Universidade de Paulo, 2012.

A leptospirose é uma doença infecto-contagiosa que acomete os animais domésticos, silvestres e o homem, causada por bactérias do gênero Leptospira. No Brasil, a hemorragia pulmonar constitui o principal fator de risco para o óbito com taxas de letalidade para essa forma da doença superior a 50\%. Mesmo com as atuais bases terapêuticas tais como a instituição de diálise precoce, melhor controle da insuficiência renal e a utilização de estratégias de ventilação protetora utilizadas nos casos de síndrome hemorrágica pulmonar na leptospirose, ainda há uma ineficácia para reduzir significativamente a alta letalidade desta forma de manifestação na leptospirose. Além disso, há grandes custos no sistema de saúde público devido à perda de dias de trabalho e à internação hospitalar. Desta maneira, o desenvolvimento de uma vacina preventiva e o melhor entendimento dos mecanismos de lesão envolvidos nos processos de desenvolvimento da leptospirose nos permitirá propor novas terapêuticas a fim de diminuir a alta letalidade associada à doença. Com o seqüenciamento de seis genomas de Leptospira aliado ao desenvolvimento de ferramentas de bioinformática, propusemos investigar doze genes de Leptospira interrogans sorovar Copenhageni. Esses genes foram selecionados por codificarem proteínas hipotéticas, de sublocalização extracelular ou secretada, cujas funções ainda não foram caracterizadas, além dos genes que codificam para a porção carboxi-terminal da proteína LigA e LytM de $L$. interrogans Copenhageni e Staphylococcus aureus respectivamente, para serem utilizados como controle em alguns experimentos. Todos os genes selecionados foram clonados, porém, somente os antígenos rLIC13435, rLIC11399 a porção carboxi-terminal das proteínas LIC11399 (ctLIC11399), LigA (ctLigA) e LytM (ctLytM) foram possíveis de expressar e purificar. O gene lic13435 está presente em variados genomas de leptospiras patogênicas e ausente no genoma de leptospira saprofítica. Entretanto, a expressão dessa proteína foi bastante variada, indicando que esta proteína talvez seja regulada e desempenhe alguma função na virulência ou patogenicidade da bactéria. No entanto, a imunização com esse antígeno não conferiu proteção em hamsters desafiados com leptospira virulentas. O gene lic11399 apresenta um domínio semelhante aos fatores V e VIII da cascata de coagulação na porção amino-terminal e um domínio semelhante ao de metalopeptidase da família M23 na porção carboxi-terminal. A proteína nativa está presente somente no genoma de leptospiras 
patogênicas e é secretada pela bactéria durante seu crescimento. Além disso, soros de humanos e hamsters com leptospirose são capazes de reconhecer a proteína recombinante rLIC11399, indicando que a proteína nativa é apresentada ao sistema imune do hospedeiro durante a infecção por leptospira. Apesar dos ensaios de proteólise realizados neste estudo detectarem uma baixa atividade elastinolítica das proteínas rLIC11399 e ctLIC11399, a identificação da proteína LIC11399 abre caminho para a investigação de uma possível protease envolvida nos processos hemorrágicos para essa importante zoonose. Em ensaios de desafio animal, a imunização de hamsters com a proteína rLIC11399 conferiu proteção em $30 \%$ dos animais. Esperamos, com os resultados apresentados neste trabalho, contribuir com a caracterização da biologia e patogenicidade da leptospirose.

Palavras chaves: Vacinas. Proteínas recombinante. Leptospirose. Leptospira interrogans Copenhageni. 


\begin{abstract}
Hashimoto, V.L. Cloning and gene expression of vaccinal candidates against leptospirosis. 2012. [Ph.D. thesis (Biotechnology)] - São Paulo - Instituto de Ciências Biomédicas da Universidade de Paulo, 2012.
\end{abstract}

Leptospirosis is an infectious disease that affects domestic animals, wildlife and humans, caused by bacteria of the genus Leptospira. In Brazil, pulmonary hemorrhage is the major risk factor to death with mortality rates for this form of the disease over than $50 \%$. Even with the current therapeutic grounds such as early institution of dialysis, better control of renal failure and the use of protective ventilation strategies used in cases of leptospirosis pulmonary hemorrhage syndrome, the reducing of the high mortality of this form of manifestation in leptospirosis is still not significant. In addition, there are large costs in the public health system due to lost of working days and hospitalizations. Thus, the development of a preventive vaccine and better understanding of injury mechanisms involved in leptospirosis would allow us to propose new therapies to reduce the high mortality associated with the disease. With the sequencing of six genomes of Leptospira coupled with the development of bioinformatic tools, we proposed to investigate twelve genes of Leptospira interrogans serovar Copenhageni. These genes were selected because they encode for hypothetical proteins with extracellular or secreted localization, whose functions have not yet been characterized, in addition to genes encoding the C-terminal portion of LigA and LytM of L. interrogans Copenhageni and Staphylococcus aureus respectively, to use as control in some experiments. All selected genes were cloned, but only the antigens rLIC13435, rLIC11399 and the C-terminal portion of proteins LIC11399 (ctLIC11399), LigA (ctLigA) and LytM (ctLytM) were possible to express and purify. The lic13435 gene is present in a varied pathogenic leptospira genomes and absent in saprophytic genome, however, the expression of this protein was inconsistent, indicating that this protein may be regulated and play a role in virulence or pathogenicity of the bacteria. Nevertheless, immunization with this antigen did not confer protection in hamster challenged with virulent leptospira. The lic11399 gene has a domain similar to factor V and VIII of the coagulation cascade in the N-terminal portion, and a domain similar to M23 metallopeptidase family at the C-terminal portion. The native protein is present only in pathogenic leptospiras genomes and is secreted by the bacteria during their growth. Furthermore, sera from humans and hamsters with leptospirosis are able to recognize the recombinant protein rLIC11399, indicating that the native protein is presented to the host immune system during infection by leptospira. Despite the proteolysis assays performed in this study detected a low elastolytic activity of rLIC11399 and ctLIC11399 proteins, the identification of LIC11399 protein opens the way for the investigation of a possible protease involved in bleeding processes in this important zoonosis. In animal test challenge, the hamsters immunization with rLIC11399 protein conferred 30\% protection. With the results presented here, we expect to contribute to the biology and pathogenicity characterization of leptospirosis. 
Keywords: Vaccines. Recombinant proteins. Leptospirosis. Leptospira interrogans Copenhageni. 


\section{LISTA DE ILUSTRAÇÕES}

Figura 1 - Microscopia eletrônica de varredura de dois espécimes de $L$. interrogans sorovar Icterohaemorrhagiae.

Figura 2 - Esquema da superfície de bactéria gram-negativa. .21

Figura 3 - Esquema ilustrando a membrana externa da leptospira. .22

Figura 4 - Taxonomia das espiroquetas. .23

Figura 5 - Mapa do vetor pGEM-T-Easy (Promega) de clonagem. 40

Figura 6 - Representação esquemática do vetor de expressão pAE. .041

Figura 7 - Gel de SDS-PAGE 15\% com curva padrão de BSA e concentrações crescentes da proteína recombinante $\mathrm{rLIC13435}$

Figura 8 - Gel de SDS-Page 12\% com curva padrão de BSA e concentrações crescentes da proteína recombinante ctLigA

Figura 9 - Gel de SDS-Page 15\% com curva padrão de BSA e concentrações decrescentes da proteína recombinante rLIC11399.

Figura 10 - Gel de SDS-Page 15\% com curva padrão de BSA e concentrações decrescentes da proteína recombinante ctLIC11399.

Figura 11 - Gel de SDS-Page 15\% com curva padrão de BSA e concentrações crescentes da proteína recombinante ctLytM.

Figura 12 - Alinhamento do gene lic13435 com genes homólogos de diferentes genomas de Leptospira.

Figura 13 - Alinhamento do gene lic11399 com genes ortólogos de diferentes genomas de Leptospira.

Figura 14 - Homologia entre a seqüência de aminoácidos de LIC11399 com a seqüência de LytM de Staphylococcus aureus. .60

Figura 15 - Imagem tridimensional da estrutura terciária das proteínas rLIC11399 e LytM.

Figura 16 - Amplificação do gene lic13435 a partir de DNAs genômicos de Leptospira...61

Figura 17 - Amplificação de transcritos gênicos lic13435 de Leptospira. 62

Figura 18 - Amplificação de transcritos gênicos de Leptospira. .63

Figura 19 - Espectro de CD associado a vários tipos de estrutura secundária .64 
Figura 20 - Espectro de CD obtido para cada proteína recombinante .65

Figura 21 - Avaliação da estrutura secundária obtida por CD..............................................66

Figura 22 - Presença de anticorpos em soros de camundongos imunizados . .67

Figura 23 - Análise da especificidade do anticorpo gerado contra a proteína rLIC13435.

Figura 24 - Análise da especificidade do anticorpo gerado contra a proteína rLIC11399 e ctLIC11399.

Figura 25 - Detecção da expressão de LIC11399 em cultivos de Leptospira .70

Figura 26 - Detecção da expressão de LIC11399 em cultivos de Leptospira 70

Figura 27 - Detecção da expressão de LIC11399 em cultivos de Leptospira .70

Figura 28 - Detecção da proteína nativa LIC13435 durante a infecção por leptospira em humanos.

Figura 29 - Detecção de anticorpos do tipo IgG dirigido contra as proteínas rLIC11399 e ctLIC11399 em soro de hamster com leptospirose. .72

Figura 30 - Detecção de anticorpos do tipo IgG dirigido contra a proteína rLIC11399 em soros de pacientes humanos com leptospirose. . .73

Figura 31 - Detecção da proteína nativa LIC11399 secretada por leptospiras..................75

Figura 32 - Adesão de rLIC13435 e rLIC11399 a componentes da MEC.........................76

Figura 33 - Imagem representativa de um ensaio de proteólise de ctLIC11399 e LipL32 sobre o subtrato Elastina-Congo Red.

Figura 34 - Imagem representativa de um ensaio de proteólise de ctLIC11399 e LipL32 sobre o subtrato Elastina-Congo Red. 79

Figura 35 - Imagem representativa de um ensaio de proteólise de ctLytM sobre o

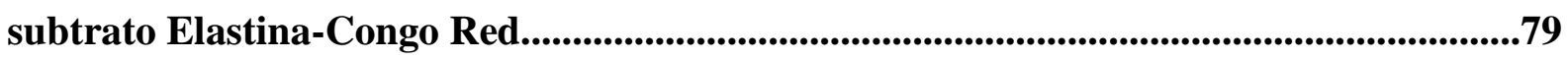

Figura 36 - Imagem representativa de um ensaio de zimografia de ctLIC11399. .80

Figura 37 - Análise da porcentagem de sobrevivência dos grupos de animais vacinados e desafiados. .81

Figura 38 - Análise da porcentagem de sobrevivência dos grupos de animais vacinados e desafiados

Figura 39 - Análise da porcentagem de sobrevivência dos grupos de animais vacinados e desafiados. 


\section{LISTA DE TABELAS}

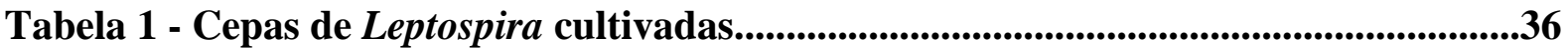

Tabela 2 - Oligonucleotídeos utilizados no seqüenciamento de plasmídeos.........................38

Tabela 3 - Oligonucleotídeos empregados na amplificação de fragmentos de DNA por

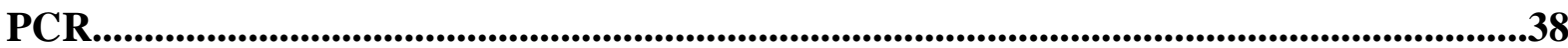

Tabela 4 - Ciclos de amplificação de fragmentos de DNA por PCR.................................39

Tabela 5 - Soro infectante e título de MAT de 7 soros de pacientes com leptospirose.........74

Tabela 6 - Atividade proteolítica sobre o substrato Elastina-Congo Red............................77

Tabela 7 - Atividade proteolítica sobre o substrato Elastina-Congo Red............................78

Tabela 8 - Avaliação do desafio animal quanto ao número de animais sobreviventes e a presença de leptospiras nos rins dos animais vacinados (portadores). 


\section{LISTA DE ABREVIATURAS E SIGLAS}

2YT - Meio de cultura contendo $1 \%$ de extrato de levedura, $1,6 \%$ de peptona e $0,5 \%$ de $\mathrm{NaCl}$

2YT-ON - Meio de cultura contendo $1 \%$ de extrato de levedura e 1,6\% de peptona

Amp - Ampicilina

BSA - Albumina bovina sérica

CD - Dicroísmo circular

cDNA - DNA complementar

DNA - Ácido desoxirribonucléico

dNTPs - Deoxinucleotídeos trifosfato

E. coli - Escherichia coli

EDTA - Ácido etileno diamino tetracético

ELISA - Enzyme-Linked Immunosorbent Assay (ensaio imunoenzimático)

EMJH - Meio Ellinghausen-McCullough-Johnson-Harris

IPTG - Isopropiltiogalactosídeo

IgG - Imunoglobulina G

IgM - Imunoglobulina M

KDa - KiloDalton

L - Litro

lac $Z$ - Promotor da beta-galactosidase

LPS - Lipopolissacarídeo

MAT - Título de aglutinação microscópica

pb - Pares de base

PBS - Phosphate buffer saline (tampão fosfato-salina)

PBS-T - Tampão fosfato contendo tween 20

PCR - Polymerase Chain Reaction (reação em cadeia da polimerase)

pH - Potencial hidrogeniônico

pI - Ponto isoelétrico

PMSF - Phenylmethylsulfonyl fluoride

OMS - Organização mundial da saúde

OPD - o-dihidrocloreto fenilenodiamina

RNA - Ácido ribonucléico

RT - Transcriptase reversa 
SDS - Dodecil sulfato de sódio

SDS-PAGE - Eletroforese em gel de poliacrilamida com SDS

SMART - Simple Modular Architecture Research Tool

SPHL - Síndrome pulmonar hemorrágica na leptospirose

T7 - Promotor do fago T7

TAE - Tampão tris-acetato e EDTA

TEMED - Tetrametilenodiamino

Tris - (Hidroxidometil) aminometano

$\mathbf{U}$ - Unidade

UV - Ultra violeta

X-Gal - 5-bromo-4-cloro-indolil- $\beta$-D-galactopiranosideo 


\section{SUMÁRIO}

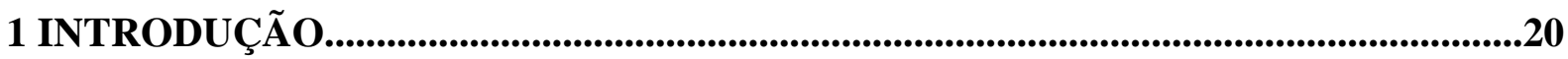

1.1 Aspectos biológicos e morfológicos da bactéria...............................................................20

1.2 Taxonomia e classificação............................................................................................22

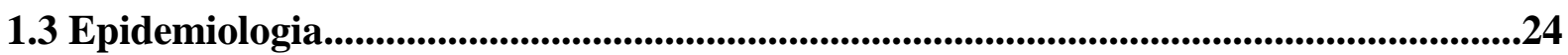

1.4 Manifestações clínicas da leptospirose humana.......................................................25

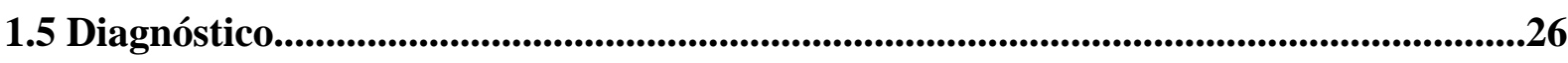

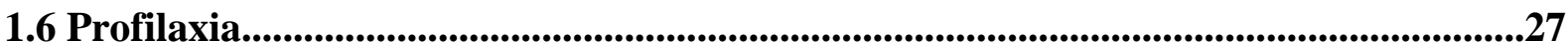

1.7 Tratamento..............................................................................................................................................28

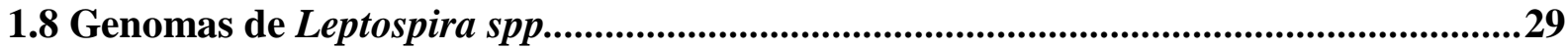

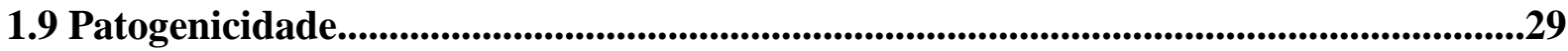

1.10 Vacinologia reversa e triagem do genoma de Leptospira interrogans sorovar

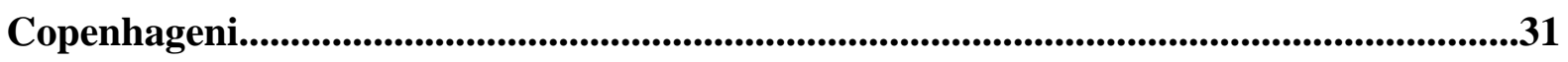

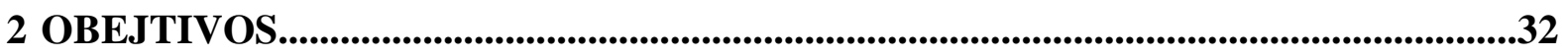

2.1 Objetivo geral..................................................................................................................................32

2.2 Objetivo específico...................................................................................................................32

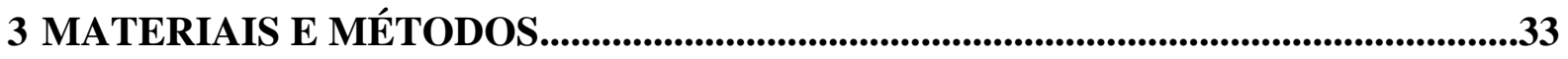

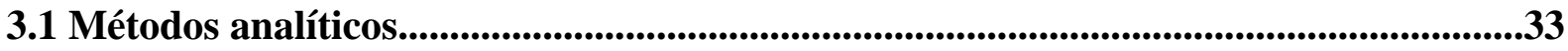

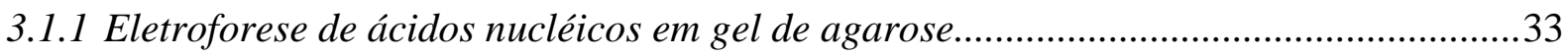

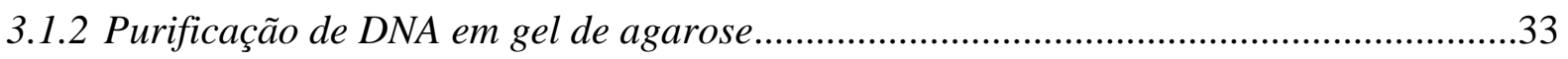

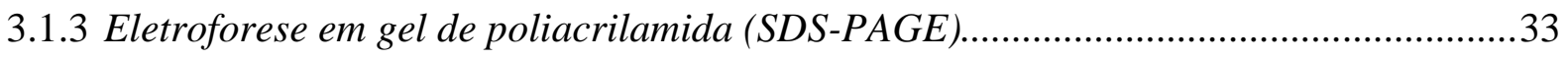

3.2 Análises in silico das características das proteínas selecionadas....................................34

3.3 Seleção de genes candidatos contra leptospirose...............................................................34

3.4 Desenho de iniciadores específicos para PCR..................................................................35

3.5 Obtenção e cultivo de cepas de Leptospira virulentas e não virulentas........................35

3.6 Obtenção e cultivo de Staphylococcus aureus ............................................................................36

3.7 Soros de pacientes com leptospirose.........................................................................................37

3.8 Extração de DNA genômico de Leptospira...........................................................................37

3.9 Extração de RNA de leptospira..............................................................................................37

3.10 Reação em cadeia da polimerase (PCR).............................................................................37

3.11 Transcrição reversa e RT-PCR (Transcriptase reversa seguida de reação em cadeia da polimerase)

3.12 Vetores recombinantes utilizados.....................................................................................40 


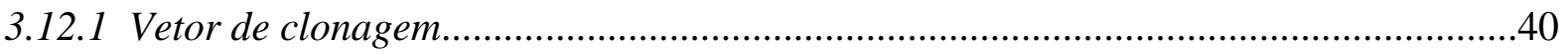

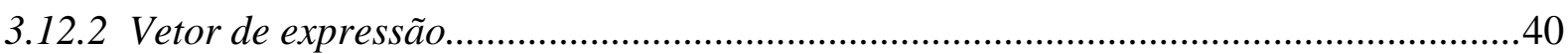

3.13 Subclonagem dos produtos de PCR.....................................................................41

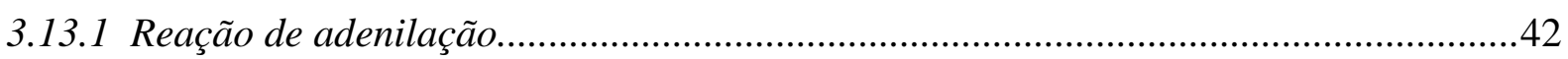

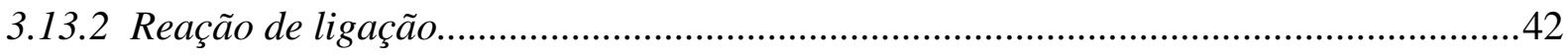

3.14 Transformação de bactérias competentes.................................................................42

3.15 Análise de plasmídeos através de extração com fenol-clorofórmio.............................42

3.16 Purificação de plasmídeos......................................................................................43

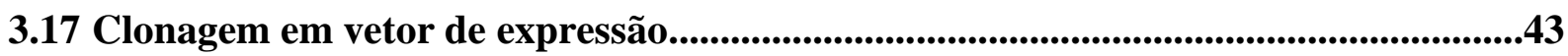

3.18 Indução protéica em bactérias de expressão e purificação...........................................44

3.19 Ensaio de dicroísmo circular.............................................................................................45

3.20 Seqüienciamento de proteína.......................................................................................45

3.21 Imunização de camundongos para obtenção de soro hiperimune..............................46

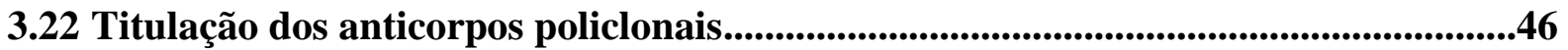

3.23 Adesão a componentes de matriz extracelular (MEC)...........................................47

3.24 Obtenção dos extratos protéicos totais de cultura de leptospira................................48

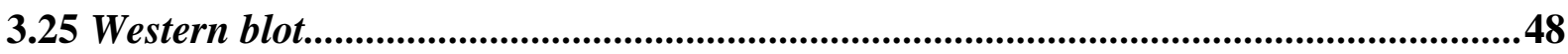

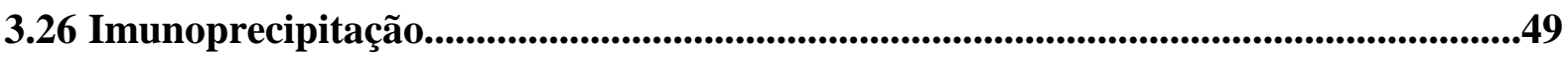

3.27 Detecção de atividade proteolítica sobre substrato elastina....................................49

3.28 Zimografia em gel de poliacrilamida com SDS........................................................50

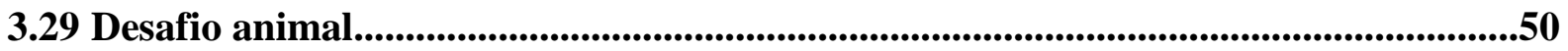

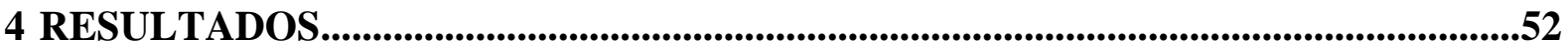

4.1 Identificação de genes...............................................................................................52

4.2 Expressão e purificação de proteínas recombinantes.................................................52

4.3 Análise bioinformática complementar do gene lic13435.........................................56

4.4 Análise bioinformática complementar do gene lic11399..............................................57

4.5 Seqüenciamento da porção amino-terminal da proteína rLIC13435.........................61

4.6 Avaliação da conservação do gene lic13435 em genomas de leptospiras

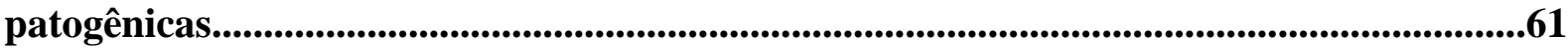

4.7 Avaliação da presença de transcritos gênicos do gene lic13435................................62

4.8 Análise da estrutura secundária por dicroísmo circular (CD).................................63

4.9 Avaliação da imunogenicidade das proteínas geradas em camundongos....................66

4.10 Análise de especificidade dos anticorpos gerados por Western blot..........................67

4.11 Análise da conservação da proteína nativa LIC13435 em Leptospira sp..................69 
4.12 Análise da conservação da proteína nativa LIC11399 em Leptospira sp .69

4.13 Detecção da proteína nativa LIC13435 durante a infecção por leptospira em

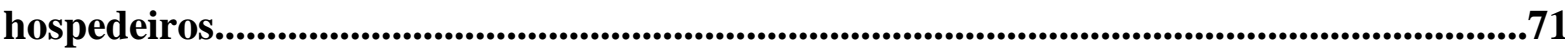

4.14 Detecção da proteína nativa LIC11399 durante a infecção por leptospira em hospedeiros..................................................................................................................................................71

4.15 Detecção da proteína nativa LIC11399 secretada em meio de cultura........................74 4.16 Avaliação da capacidade das proteínas rLIC13435 e rLIC11399 de interagir com componentes de matriz extracelular (MEC) .75

4.17 Avaliação da atividade elastinolítica das proteínas recombinantes rLIC11399 e ctLIC11399. .76

4.18 Avaliação da atividade elastinolítica de ctLIC11399 por zimografia. .79

4.19 Ensaio de proteção contra desafio homólogo...................................................................80

5 DISCUSSÃO

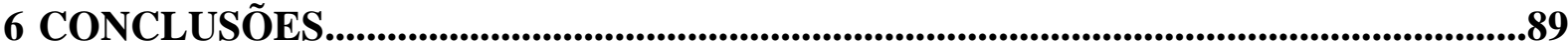

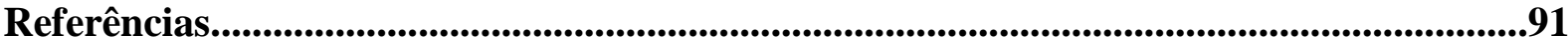

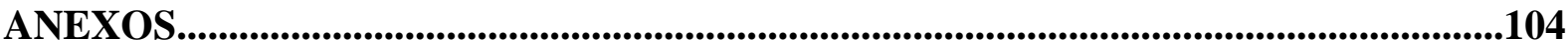

Anexo A - Alinhamento dos genes selecionados com genes homólogos de diferentes genomas de Leptospira 104

Anexo B - Manuscrito: Failure of LIC13435 Protein of Leptospira interrogans Serovar Copenhageni to Confer Protection in Immunized Hamsters 


\section{INTRODUÇÃO}

\subsection{Aspectos biológicos e morfológicos da bactéria}

As leptospiras são bactérias helicoidais, altamente móveis, aeróbicas obrigatórias, constituídas por uma membrana citoplasmática, parede celular de peptideoglicano e uma membrana envolvente contendo porinas que permitem a troca de soluto entre o espaço periplásmático e o ambiente $(1,2)$. Variam de 6 a $25 \mu \mathrm{m}$ de comprimento por cerca de $0,1 \mu \mathrm{m}$ de diâmetro (figura 1). A membrana externa contém lipopolissacarídeo (LPS) e diversas lipoproteínas. Os LPSs de leptospiras possuem composição química única, quando comparados aos demais Gram-negativos. Os LPSs são compostos por três segmentos ligados covalentemente: lipídeo A, core, e antígeno $\mathrm{O}$, que consiste em grupos polissacarídicos altamente variáveis. $\mathrm{O}$ antígeno $\mathrm{O}$ é considerado o principal agente antigênico dos LPSs das bactérias gram-negativas (3). A porção do lipídio A exibe uma composição de ácidos graxos incomum e um único resíduo de fosfato metilado (4-6). O core é uma porção polissacarídica que forma a região intermediária (figura 2).

Figura 1 - Microscopia eletrônica de varredura de dois espécimes de L. interrogans serovar Icterohaemorrhagiae aderidos a uma membrana de filtração de $0,2 \mathrm{~mm}$.

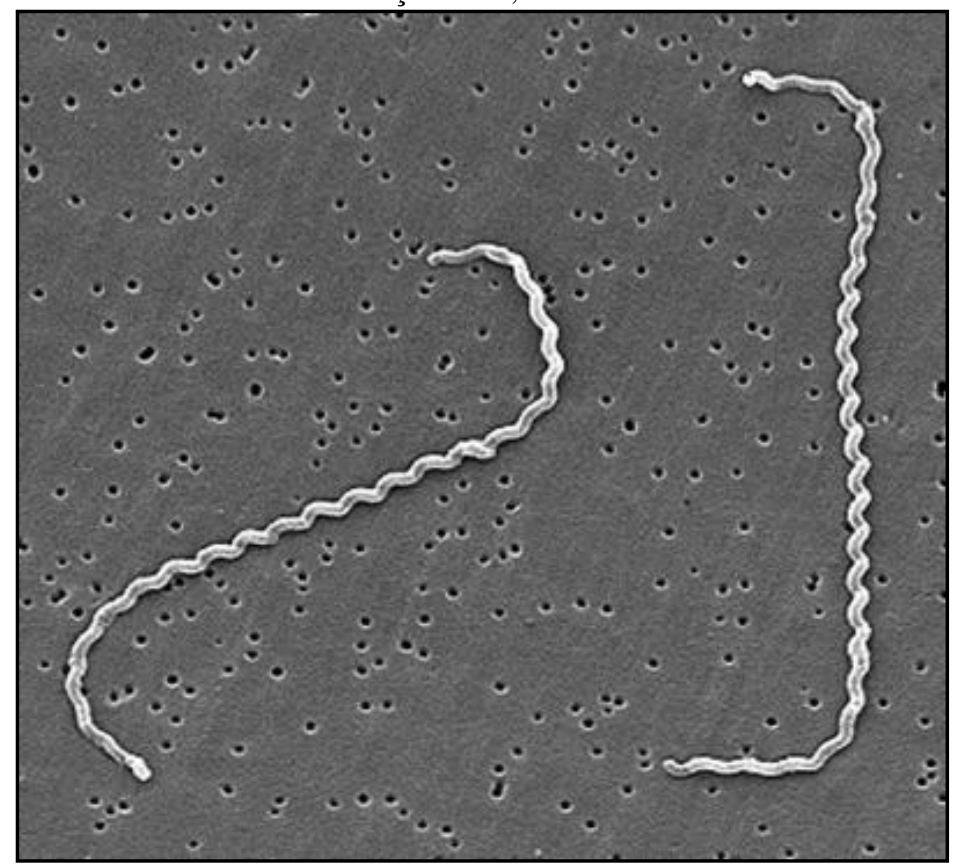

Fonte: Reproduzido de Levett (2001). 
Figura 2 - Esquema da superfície de bactéria gram-negativa. Modelo molecular da membrana interna e externa de E. coli K-12. Conforme indicado, as formas geométricas ovais e retangulares representam resíduos de açúcar, enquanto que círculos representam grupos polares de vários lipídeos. PPEtn: pirofosfato de etanolamina; LPS: lipopolissacarídeo; Kdo: 2-keto-3-ácido deoxiotonico.

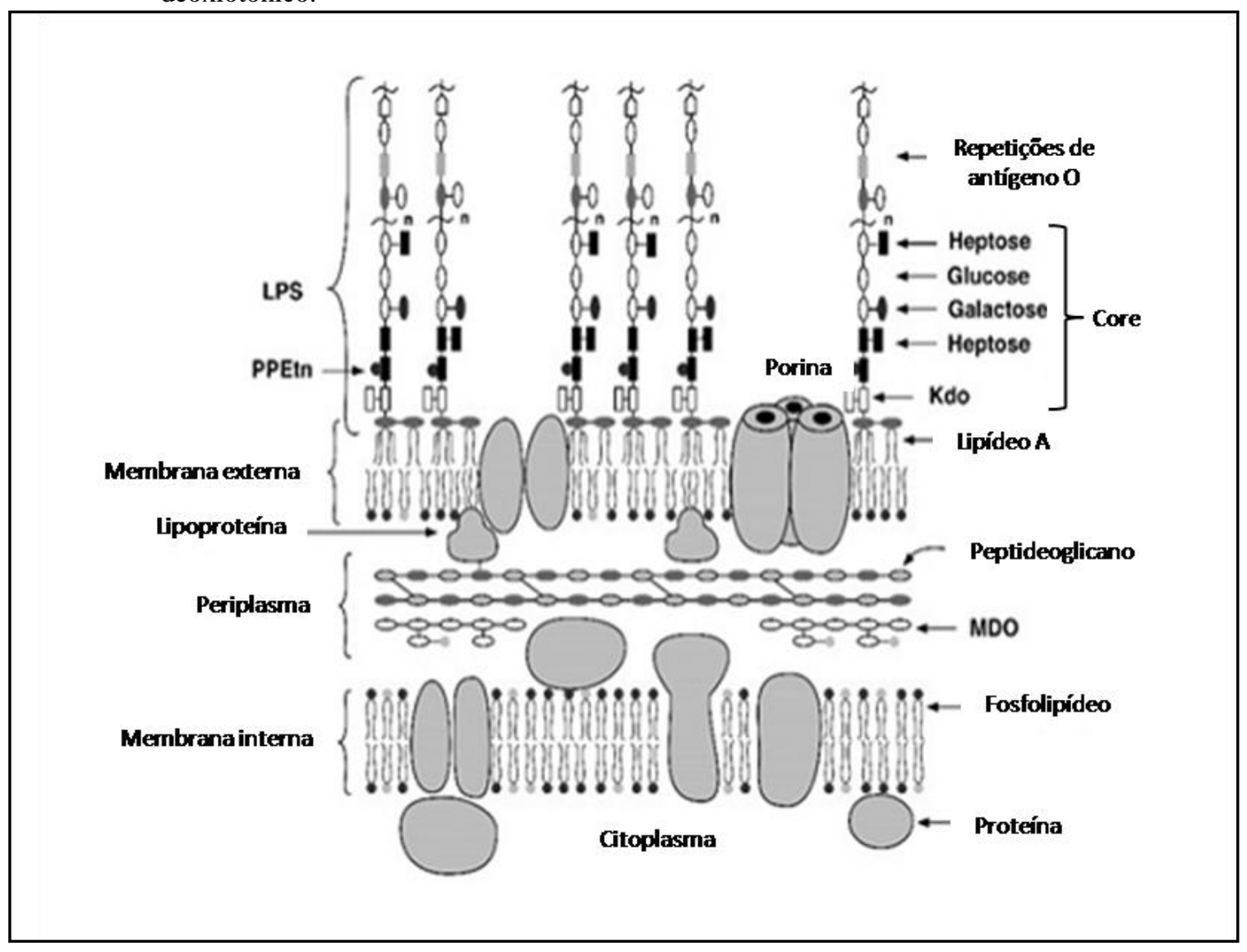

Fonte: Modificado de Raetz et. al.(7)

A motilidade da Leptospira deve-se à presença de dois flagelos periplasmáticos, cada um ancorado subterminalmente em uma das extremidades da bactéria e que se estendem em direção ao centro (figura 3) $(8,9)$. Periodicamente, os eixos contraem-se, levando à rotação dos flagelos e assim, movimentação da bactéria.

Os habitats das Leptospira são diversos, pois podem se estabelecer em ambientes como lama, águas de esgoto, trato digestivo de moluscos, e em túbulos renais de mamíferos (10), devido a sua capacidade de agregação celular e formação de biofilme $(11,12)$.

No meio ambiente, as leptospiras requerem, para sua sobrevivência, solo com pH levemente alcalino em torno de 7,2 a 7,4, e, de preferência, com grande umidade. No entanto, as leptospiras não resistem ao calor, desidratação e à água salgada $(13,14)$. 
Figura 3 - Esquema ilustrando a membrana externa, cilindro celular protoplasmático e o flagelo periplasmático das espiroquetas.

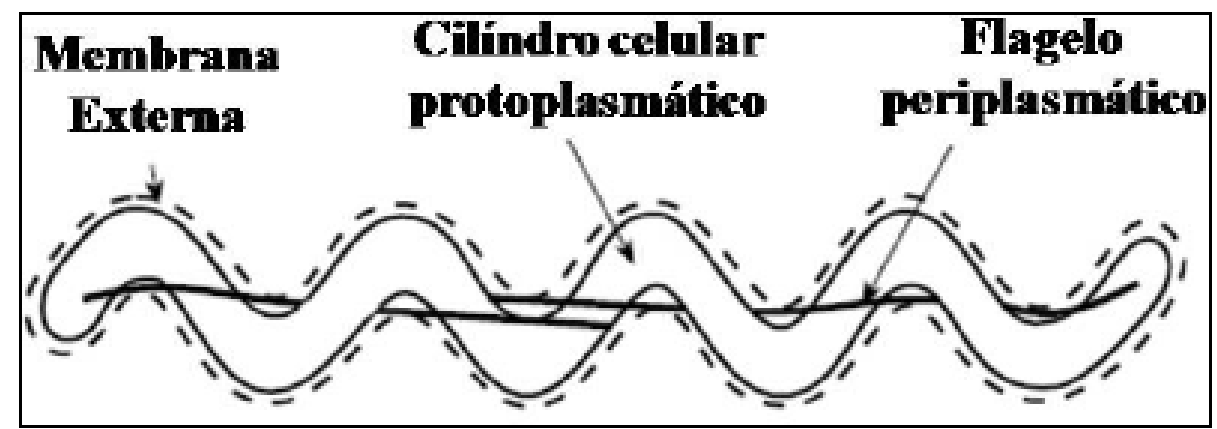

Fonte: Adapatado de Charon et. al. (10).

São bactérias de difícil cultivo que não se coram pelos métodos usuais de coloração. A sua principal fonte de energia são os ácidos graxos de cadeia longa, sendo a amônia e o ferro nutrientes essenciais. Por estas características, para seu crescimento em meio artificial, são necessários meios especiais enriquecidos com albumina bovina, soro de coelho e vitaminas B1 e B2. O meio de cultura mais utilizado para seu cultivo é o meio EllinghausenMcCullough-Johnson-Harris (EMJH), que contém ácido oléico, soro albumina bovina como detoxificante e tween 80 como fonte de carbono (15-17). O crescimento em meio de cultura pode variar de dois a 30 dias (3).

\subsection{Taxonomia e classificação}

A classificação taxonômica das leptospiras está em constante revisão, devido aos avanços em biologia molecular.

Leptospiras são filogeneticamente relacionadas a outras espiroquetas (18). Estas bactérias pertencem à classe das Spirochaetes, ordem Spirochaetales, e estão divididas em três famílias, Spirochaetaceae que contém espécies do gênero Borrelia, Brevinema, Cristipira, Spirochaeta, Spironema e Treponema. A segunda família Brachyspiraceae, contém o gênero Brachyspira (Serpetulina). A terceira família, Leptospiraceae, contém espécies dos gêneros Leptonema e Leptospira. Na figura 4 está representado um esquema simplificado da taxonomia das espiroquetas.

O gênero Leptospira foi inicialmente dividido em duas espécies, através de sorologia, baseada em determinantes antigênicos: Leptospira interrogans sensu lato (bactérias patogênicas) e Leptospira biflexa sensu lato (bactérias saprofíticas e/ou de vida livre). 
A sorologia foi o método utilizado para a classificação das leptospiras até o final da década de 1980 (19). A classificação sorológica é fundamentada em testes de aglutinação microscópica (MAT). Utilizando-se o MAT, os sorovares são classificados dentro de sorogrupos determinados pelos antígenos que são compartilhados (sorogrupo-específico) (3), podendo muitas vezes ocorrer reações cruzadas entre diferentes sorovares. Assim sendo, as espécies de Leptospiras são classificadas dentro de mais de 250 sorovares. A diversidade dos sorovares é devido à heterogeneidade de carboidratos que compõem a cadeia lateral dos lipopolissacarídeos (LPS) da membrana bacteriana.

Com o desenvolvimento das técnicas de hibridização do DNA e da análise de homologia DNA-DNA, a classificação das leptospiras vem sofrendo modificações. A classificação molecular do gênero Leptospira é baseada no grau de hibridização de DNA. Atualmente, o gênero divide-se em 20 espécies definidas, que incluem espécies patogênicas, não-patogênicas e intermediárias (espécies cuja patogenicidade ainda não foi determinada)(20-23). Essa classificação coexiste com a classificação antiga, baseada no MAT. No Brasil, os sorovares mais freqüentes causadores de doença em humanos são Copenhageni e Icterohemorrhagiae (24-26).

Figura 4 - Taxonomia das espiroquetas. A figura apresenta uma versão simplificada da taxonomia das espiroquetas focando nos gêneros importantes do ponto de vista clínico. Nos quadrado do organograma estão assinaladas em vermelho as doenças causadas pelas bactérias.

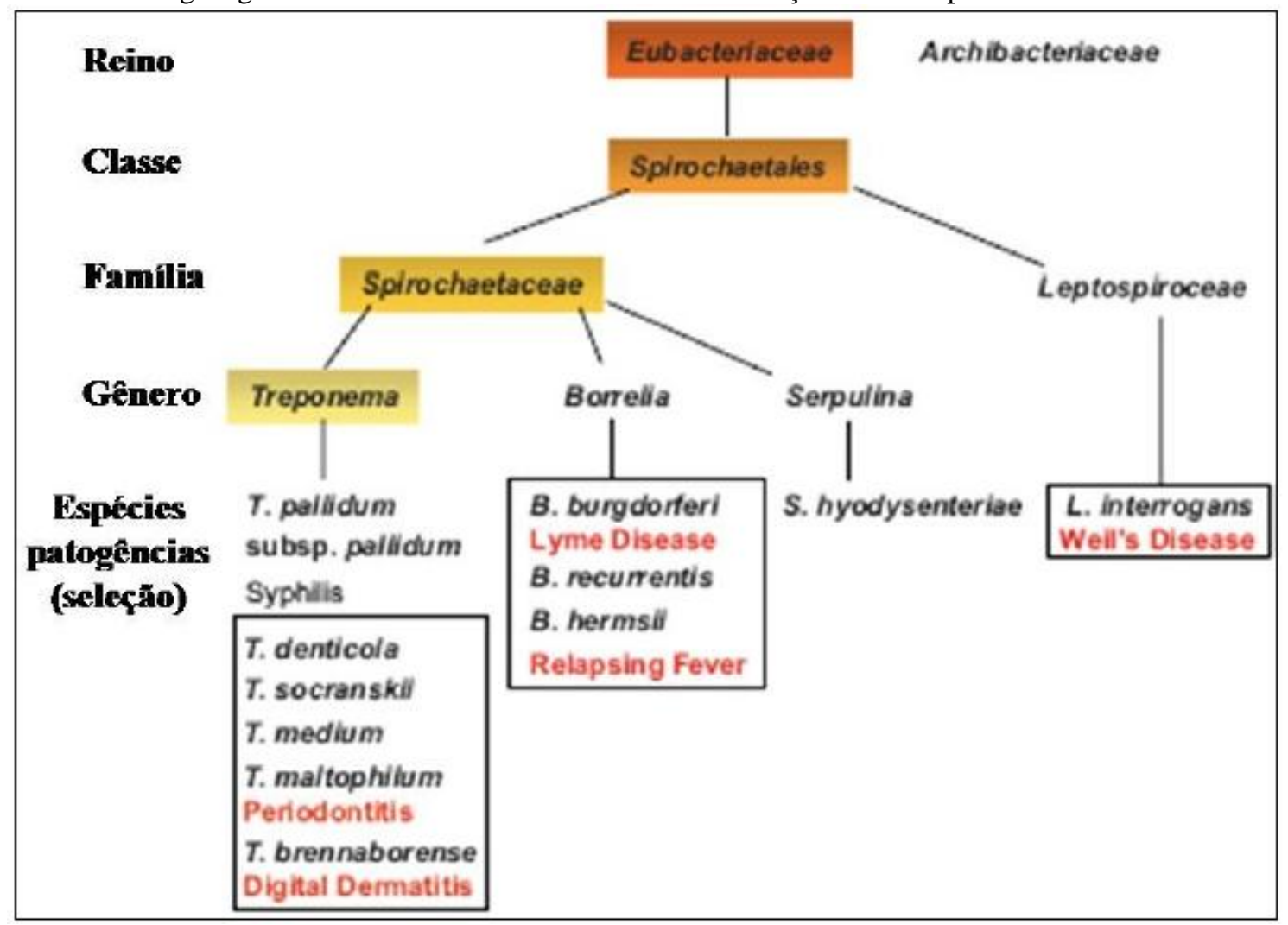

Fonte: Modificada de Schoder et.al. (27). 


\section{$1.3 \quad$ Epidemiologia}

A leptospirose é considerada a zoonose mais difundida no mundo. $\mathrm{O}$ agente infectante é transmitido de um mamífero infectado para outro através do contato direto, ou indireto, com a urina de animais infectados, ou através de veículos inanimados, tais como solo, água ou utensílios contaminados. A Leptospira é mantida no ambiente através de animais carreadores que apresentam colonização persistente dos túbulos renais proximais, eliminando a bactéria por longos períodos sem apresentar sintomas de doença (3).

A incidência é mais significativa em países ou regiões de clima tropical e subtropical em desenvolvimento com alto índice pluviométrico (3, 13, 28-31).

A alta prevalência em países em desenvolvimento está associada com o crescimento populacional urbano e ausência de saneamento básico que constitui um fator essencial na proliferação de roedores, a principal fonte de infecção humana $(3,32)$. Nesta situação, os grupos sócio-econômicos menos privilegiados, com dificuldade de acesso à educação e saúde, residentes em regiões periféricas às margens de córregos ou próximos de esgotos a céu aberto são expostos a freqüentes enchentes e, portanto, maior risco de contrair a infecção. Em países desenvolvidos, com infra-estrutura de saneamento adequado, a população está menos exposta ao contágio. A infecção ocorre de forma ocupacional e em surtos associados à pratica esportiva em água e solos contaminados $(13,20,33)$.

A exposição ocupacional é um fator de risco significante $(20,34)$, podendo atingir diversas categorias profissionais como trabalhadores rurais, mineiros, abatedores de animais, trabalhadores da rede de saneamento e médicos veterinários. Entretanto, a real incidência de leptospirose no mundo não é precisamente determinada, seja por falhas nos sistemas públicos de vigilância e prevenção, seja pela baixa suspeita clínica de leptospirose devido ao alto número de casos subclinicos, e por semelhanças com outras doenças infecciosas que ocorrem concomitantemente (por exemplo, a dengue) (35). Somente nos últimos anos a leptospirose ganhou atenção como um importante problema de saúde pública global. Atribui-se este reconhecimento à emergência de SPHL (síndrome pulmonar hemorrágica na leptospirose) em todo o mundo (36-43). A hemorragia pulmonar na leptospirose é a manifestação mais letal nesta doença com taxa de mortalidade superior a 50\% (44).

No Brasil, a hemorragia pulmonar constitui o principal fator de risco para o óbito com taxas de letalidade que variam entre $55 \%$ a $74 \%(45,46)$. Mesmo com as atuais bases terapêuticas tais como a instituição de diálise precoce, melhor controle da insuficiência renal e a utilização de estratégias de ventilação protetora utilizadas nos casos de SPHL, ainda há uma 
ineficácia para reduzir significativamente a alta letalidade desta forma de manifestação na leptospirose (47).

Embora o potencial hemorrágico da leptospirose ter sido descrita em 1886 por Weil, e, diversos estudos tenham se focado para esta forma da doença $(45,48-54)$, o mecanismo de sua fisiopatologia ainda não foi completamente elucidado.

\subsection{Manifestações clínicas da leptospirose humana}

A leptospirose apresenta amplo espectro de manifestações clínicas em humanos, desde quadros leves a quadros mais graves, por vezes fulminantes $(33,55)$. A doença ocorre pela penetração ativa dos microrganismos através de mucosas (ocular, digestiva, respiratória, e genital), ou por meio da pele lesada ou mesmo íntegra $(3,13,20)$. Após a penetração leptospiras percorrem as vias linfáticas e sanguíneas, atingindo sítios de difícil acesso para os anticorpos, como túbulos renais, fígado, cérebro e olhos, onde persistem e se multiplicam. O período de incubação da doença até o surgimento dos sintomas é variável, geralmente de sete a quatorze dias em média, porém, períodos mais curtos podem ocorrer em casos de alta carga bacteriana infectante. Após o período de incubação, podem ocorrer duas síndromes clínicas distintas, com $90 \%$ dos pacientes apresentando uma doença febril anictérica e $10 \%$ doença severa com icterícia e manifestações hepáticas e renais (síndrome de Weil) (20). Embora a forma anictérica seja mais freqüentemente observada, ambas as formas podem seguir um curso bifásico caracterizado por uma fase de septicemia e uma fase imune $(3,20)$.

$\mathrm{Na}$ forma anictérica a grande maioria das infecções é subclínica ou de baixa severidade e a resolução coincide com o surgimento de anticorpos (20). Os indivíduos sintomáticos apresentam na primeira fase, conhecida como fase septicêmica, febre súbita, calafrios, cefaléia, mialgias, erupções cutâneas, náuseas, vômitos, derrame conjuntival e prostração. Nesta fase as leptospiras podem ser isoladas do sangue, liquor e tecidos $(3,20)$. Seguindo-se a defervescência da febre e demais sintomas, inicia-se a fase imune, caracterizada pela produção de anticorpos. Nesta fase as leptospiras desaparecem do sangue e liquor, mas podem ainda ser encontradas no rim, urina e humor aquoso $(56,57)$. Em alguns pacientes a febre retorna associada a sintomas neurológicos como cefaléia, fotofobia e rigidez na nuca, caracterizando um quadro de meningite asséptica que consiste na principal manifestação clínica desta fase (32).

Diferentemente da forma anictérica, a forma ictérica da leptospirose, conhecida como Síndrome de Weil, é geralmente grave. Ocorre em 5\% a 15\% dos casos e sua mortalidade 
varia de $5 \%$ a $40 \%$. Esta forma da doença é caracterizada pela falência das funções hepáticas e renais, hemorragia, colapso vascular e alteração severa da consciência (3, 20, 29). Manifestações hemorrágicas são freqüentes e caracterizadas por petéquias, púrpura, hemorragias conjuntival, gastrointestinal e pulmonar. As formas pulmonares graves como a SPHL representam uma evolução da Síndrome de Weil, com instalação precoce de insuficiência respiratória aguda, muitas vezes precedendo quadro de icterícia e disfunção renal. Os sintomas pulmonares incluem tosse, dispnéia e hemoptise de severidade variada (24, 58). O óbito pode ocorrer nas primeiras 24 horas de internação, por asfixia causada por profusa hemorragia bronco-pulmonar. Essa forma severa da doença de Weil têm sido relatada com freqüência no Brasil, principalmente no Estado de São Paulo, onde está presente em 72\% dos casos graves, com taxa de letalidade global de $17 \%(26,49,59)$.

\subsection{Diagnóstico}

Devido à ampla sintomatologia da leptospirose, o diagnóstico deve ser feito baseado em elementos do ambiente epidemiológico associado a manifestações clínicas do paciente, porém, a confirmação da leptospirose só é possível através de diagnóstico laboratorial (60).

Entre os métodos sorológicos, o mais utilizado é o teste de aglutinação microscópica (MAT), que também é considerado o teste "Padrão Ouro" pela Organização Mundial de Saúde (OMS). Nesta técnica, diluições seriadas do soro do paciente são incubadas a $37{ }^{\circ} \mathrm{C}$ com uma suspensão de leptospiras vivas ou inativadas. Após a incubação, a mistura soroantígeno é examinada por microscopia de campo escuro para a observação de aglutinação e para a determinação dos títulos de diluição. Entretanto, a interpretação deste teste é complicada pela alta proporção de reações cruzadas que ocorrem entre diferentes sorogrupos, especialmente em amostras colhidas na fase aguda da doença (20). Resultados falsos negativos podem ocorrer quando o sorovar causador não está incluído na bateria de testes (61). Contudo, esta técnica é cara, de execução trabalhosa exigindo pessoas experientes e qualificadas, estando restrita a poucos laboratórios de referência. A necessidade de culturas vivas de sorovares variados requer meio de cultura complexo, manutenção e repiques freqüentes, necessidade de microscópio de campo escuro além de oferecer o risco de contaminação local $(62,63)$.

Devido à complexidade do MAT, testes rápidos de triagem para detecção de anticorpos anti-leptospira, durante a fase aguda da infecção, foram desenvolvidos (20). Entre eles: o teste hemolítico (64), a aglutinação macroscópica (SAT-Slide Agglutination Test) (65, 
66), o ensaio de hemaglutinação indireta $(20,67,68)$, a imunofluorescência indireta (69), o teste de aglutinação em microcápsula (70) e o ensaio imunoenzimático - ELISA, (Enzymelinked immunosorbent assay) (71, 72). Com o advento de técnicas de biologia molecular, métodos moleculares estão sendo desenvolvidos, principalmente baseados na detecção do DNA leptospiral em material clínico. Para esse fim, têm se utilizado dot-blotting (73), hibridização in situ (74) e PCR (75). A PCR é um método molecular rápido e sensível em especial durante os primeiros dias de doença antes da soro-conversão, sendo útil também para distinguir sorovares patogênicos dos não patogênicos (76-78). Vários pares de primers para a detecção por PCR têm sido descritos, freqüentemente baseados nos genes 16S ou 23S rRNA e em elementos repetitivos da bactéria $(20,79)$. No entanto, estes testes diagnósticos ainda estão sendo padronizados e não são aceitos como métodos de referência (20,63), pois apesar de serem altamente sensíveis e específicos, eles não têm sido sistematicamente comparados entre si e com o teste padrão (MAT) (63).

\subsection{Profilaxia}

Estratégias de prevenção e controle da leptospise incluem medidas direcionadas aos reservatórios, aos fatores ambientais e ao homem (80). O risco de transmissão pode ser reduzido nos centros urbanos através da melhoria das condições de infra-estrutura básica (rede de esgoto, drenagem de águas pluviais, coleta adequada do lixo) e da eliminação dos roedores. O controle da população de roedores, por meio de medidas de anti-ratização e desratização diminui o nível de contaminação ambiental, e, conseqüentemente, reduz o risco de contaminação humana. A adoção de equipamentos de proteção, como botas, roupas e luvas impermeáveis protegem indivíduos expostos à contaminação ocupacional. Entretanto, estas medidas tradicionais não são praticáveis em países em desenvolvimento devido às dificuldades econômicas (80).

Para indivíduos com alto risco de contaminação, pode-se recomendar a admistração de antibiótico profilático (pré-exposição). As populações mais indicadas a receber esse tipo de tratamento são militares, bombeiros e profissionais que irão se submeter à situação de risco por um tempo limitado.

No âmbito veterinário, estão disponíveis no mercado vacinas obtidas a partir de preparação de leptospiras atenuadas ou inativadas por formaldeído ou calor. Porém, a resposta imune desencadeada a partir dessas preparações é ativada, principalmente, pela porção polissacarídica dos LPSs das bactérias. Esses antígenos estimulam uma resposta timo 
independente, não induzindo, portanto, proteção a longo prazo contra infecção, o que torna necessária sua administração anual ou semestral (81). Além disso, são sorovares específicas, ou seja, não promovem proteção cruzada contra leptospiras de sorovares não contidas na preparação vacinal $(3,20)$.

Diversas vacinas para prevenir a leptospirose humana têm sido desenvolvidas. Países como Cuba (82, 83), Rússia (84) e China (85) têm realizado extensos ensaios clínicos para avaliação dessas vacinas. No entanto, essas vacinas apresentam problemas semelhantes às de uso veterinário, sendo sorovar-específica e requerendo administração periódica. Portanto, ainda não existe uma vacina eficiente para uso humano, nem veterinário.

A diversidade antigênica observada entre os sorovares de Leptospira deve-se às variações de carboidratos na cadeia lateral do LPS, dificultando a elaboração de uma vacina de LPSs multivalente. Por isso, a identificação e o conhecimento da expressão de proteínas antigênicas durante a infecção pode ser uma ferramenta importante no desenvolvimento de vacinas. Atualmente, diversos grupos de todo o mundo estão concentrados na identificação de proteínas relacionadas à patogenicidade ou virulência, e que tenham um amplo espectro de conservação dentre os principais sorovares patogênicos ao homem, para a elaboração de uma vacina protéica eficaz e que confira proteção a longo prazo (86-92).

\subsection{Tratamento}

O tratamento da leptospirose depende da forma clínica da doença. O tratamento clássico da leptospirose consiste em antibioticoterapia específica, reposição de fluídos, correção dos distúrbios hidroeletrolíticos como a hipopotassemia e analgesia para as dores musculares. Casos graves, com doença de Weil, necessitam de terapia dialítica para tratamento da uremia e ventilação mecânica para os casos com insuficiência respiratória (93, 94).

O tratamento antibiótico da leptospirose é feito com penicilina cristalina ou ampicilina via intravenosa para casos graves. Doxicilina, ampicilina e amoxicilina podem ser prescritas para casos leves e moderados $(13,33)$. Entretanto, não há antibiótico capaz de reverter o dano causado em tecidos e órgãos $(3,20)$.

Nos casos de insuficiência e falência renal, o procedimento indicado é a diálise peritoneal e, a diálise deve ser mantida até que a função renal volte ao normal. Nos quadros mais severos com presença de hemorragias, é necessária a transfusão de sangue ou de plaquetas $(3,55)$. 


\subsection{Genomas de Leptospira spp.}

Os maiores avanços na compreensão da patogênese de Leptospira spp. foram possíveis graças ao recente seqüenciamento de duas espécies de Leptospira patogênicas, Leptospira interrogans (95-97) e Leptospira borgpetersenii (98), e da espécie saprofítica Leptospira biflexa (99). De acordo com estes estudos, o genoma de Leptospira é composto de dois cromossomos circulares (CI e CII) de aproximadamente $4 \mathrm{Mb}$ e $300 \mathrm{~Kb}$ respectivamente (96), enquanto que a espécie saprofítica possui um replicon adicional de $74 \mathrm{~Kb}$, denominado de P74. Embora o replicon P74 possua genes essenciais de metabolismo basal presente no cromossomo maior das espécies patogênicas, este é considerado um elemento extracromossomal ou plasmídeo (100) e não um cromossomo como se supunha (99).

Uma análise comparativa das sequiências obtidas até então revelam que $61 \%$ dos genes estão presentes em todos os genomas de Leptospira seqüenciados, distribuídos nos dois cromossomos, indicando que possa representar o conjunto gênico do progenitor ancestral que existiu antes da divergência entre espécies patogênicas e saprofíticas (99). A maioria dos genes $(77 \%$ - $81 \%)$ que compõe o genoma de Leptospira não possui ortólogos nos genomas de outras espiroquetas, indicando um grande distanciamento das leptospiras dos demais membros do phylum durante o processo evolutivo $(18,100)$. O estudo dos genes que codificam proteínas imunogênicas e virulentas tem sido o eixo principal de diversas pesquisas para a compreensão da patogenia da leptospirose e para o desenvolvimento de vacinas.

\subsection{Patogenicidade}

O sistema imune inato constitui a primeira linha de defesa do hospedeiro, desempenhando um papel crucial no reconhecimento e eliminação de leptospiras. A superfície bacteriana é a interface entre o patógeno e o hospedeiro e diferenças nas proteínas de membrana externa podem refletir na variação de mecanismos de patogenicidades.

Para estabelecer e manter a infecção, leptospiras patogênicas interagem com uma grande quantidade de componentes de matriz extracelular e outros componentes do hospedeiro tais como laminina, colágeno tipo I e IV, fibronectina celular e plasmática, fibrinogênio, elastina e proteoglicanos (101-104) através de fatores de virulência chamadas de adesinas. Além disso, Leptospira interrogans são capazes de aderir em células endoteliais, 
monócitos / macrófagos, linhagens de células em cultura do epitélio renal e fibroblastos em ensaios realizados in vitro $(105,106)$.

É importante ressaltar que leptospiras virulentas, além de serem patógenos extracelulares, são microrganismos altamente invasivos e também são capazes de aderir e invadir células hospedeiras mais eficientemente que linhagens não virulentas e/ou saprofíticas (106). De fato, foi demonstrado que cepas patogênicas translocam-se através de células Madin-Darby renal canino (MDCK) polarizadas em monocamadas em uma taxa significantemente maior que Leptospiras não patogênicas (107). Alguns autores também especulam que a bactéria patogênica possui um breve período intracelular permitindo-a escapar do sistema complemento e anticorpos. Foi demonstrado que Leptospira interrogans é capaz de escapar do fagolisossomo para o citossol de linhagens de macrófagos humanos (108).

Com relação à hemorragia pulmonar, a principal causa de morte por leptospirose no Brasil, estudos propõem a ação de toxinas e processos auto-imunes como responsáveis para esta condição. A baixa quantidade de bactérias recuperadas do tecido pulmonar sugere uma possível toxina bacteriana circulante, produzida de algum lugar distante como o fígado (109). Apesar da toxina responsável ainda não ter sido identificada, há uma grande quantidade de genes codificantes para hemolisinas e proteases, nos genomas de Leptospira patogênicas, que podem estar relacionadas com os danos pulmonares $(95,97,98)$. Também foi demonstrado em cobaias e humanos que um possível mecanismo auto-imune está presente na patogênese da SPHL, através da deposição linear de imunoglobulinas (48) e complemento ao longo da membrana basal do epitélio pulmonar e no espaço intra-alveolar (110, 111). A identificação da possível toxina permitiria uma melhor compreensão do mecanismo de patogenia para esta forma da doença e o desenvolvimento de uma possível terapia anti-toxina, que proporcionaria uma redução de incidência de SPHL e, conseqüentemente, redução das altas taxas de mortes por leptospirose.

Assim sendo, a melhor compreensão dos mecanismos de infecção e evasão das leptospiras bem como a identificação dos fatores de virulência e toxinas pode auxiliar no desenvolvimento de melhores bases terapêuticas para o tratamento da doença e no desenvolvimento de vacinas profiláticas eficientes contra leptospirose. 


\subsection{Vacinologia reversa e triagem do genoma de Leptospira interrogans sorovar Copenhageni}

O seqüenciamento do genoma de Haemophilus infuenzae, o primeiro microrganismo a ter o genoma seqüenciado, em 1995, revolucionou o campo da vacinologia (112). Concomitantemente, os avanços no campo da biologia molecular, bioinformática e tecnologia de seqüenciamento viabilizaram a seleção de candidatos in silico e, conseqüentemente, o desenvolvimento de inúmeros algoritmos para o desenho de possíveis antígenos. Essa abordagem, chamada de vacinologia reversa, permitiu a identificação de potenciais antígenos vacinais independente de suas características de expressão e sem a necessidade do cultivo do patógeno $(92,113-118)$. Esta estratégia foi empregada com sucesso primeiramente no desenvolvimento de vacinas contra Neisseria meningitidis, sorogrupo B (119) e, subseqüentemente, em diversos microrganismos tais como Streptococcus pneumoniae (120), Porphyromonas gingivalis (121) entre outros.

Atualmente, como mencionado anteriormente, estão disponíveis publicamente os seqüenciamentos genômicos de seis cepas de leptospiras, compreendendo duas espécies patogênicas e uma espécie saprofítica. A partir da sequiência genômica de Leptospira interrogans sorovar Copenhageni, foram selecionados para o presente estudo doze genes para clonarmos e expressarmos as proteínas recombinantes correspondentes para avaliarmos o seu potencial vacinal. Os genes selecionados são: lic10881, lic20087, lic11211, lic10544, lic10291, lic13435, lic11399, lic10642, lic10359, lic12558, lic10995 e lic10462. Estes genes foram selecionados por codificarem proteínas hipotéticas (com função desconhecida), com sequiência sinal, indicando que são proteínas secretadas ou que são proteínas da membrana externa. 


\section{OBJETIVOS}

\subsection{Objetivo geral}

Caracterizar o potencial antigênico e papel biológico de proteínas hipotéticas selecionadas do genoma de L. interrogans sorovar Copenhageni.

\section{$2.2 \quad$ Objetivo específico}

- Identificar 12 proteínas hipotéticas cuja localização celular seja de superfície externa ou secretada para clonar, expressar e purificar as respectivas proteínas.

- Avaliar a conservação dessas proteínas entre diferentes sorovares e espécies de Leptospira spp. e a capacidade de interação com componentes de matriz extracelular.

- Avaliar a imunoreatividade frente a soros de pacientes diagnosticados com leptospirose e hamster infectados experimentalmente.

- Caracterizar o potencial antigênico e protetor contra leptospirose. 


\section{MATERIAIS E MÉTODOS}

\subsection{Métodos analíticos}

\subsubsection{Eletroforese de ácidos nucléicos em gel de agarose}

Os géis de eletroforese em agarose foram preparados derretendo-se agarose $(0,8$ a $1 \%$ (p/v)) em tampão TAE (Tris Acetato 40 mM pH 8,5, EDTA $1 \mathrm{mM}$ ), com a adição de solução de brometo de etídio $(10 \mathrm{mg} / \mathrm{mL})$ para concentração final de $0,4 \mu \mathrm{g} / \mathrm{mL}$. As amostras foram aplicadas nos géis com a adição de solução de amostra 10x (azul de bromofenol 0,25\% (p/v), xileno cianol FF 0,5\% (p/v), glicerol 50\% (v/v)). As corridas foram feitas em tampão TAE, sob voltagem de 60 a $80 \mathrm{~V}$, até que a frente do corante atingisse a extremidade do gel. O DNA foi visualizado sob luz UV para análise ou excisão para purificação.

O padrão molecular usado nos géis de agarose foi o DNA de fago Lambda, digerido com HindIII (125 a 23,130 bp).

\subsubsection{Purificação de DNA em gel de agarose}

O produto da reação de PCR ou digestão de plasmídeos foi submetido à eletroforese em gel de agarose e, após a migração, a banda de interesse foi excisada para purificação com o auxilio de uma lâmina de bisturi. O DNA foi purificado da agarose utilizando-se o kit "GFX ${ }^{\mathrm{TM}}$ Gel Band Purification" (GE Healthcare), conforme as recomendações do fabricante.

\subsubsection{Eletroforese em gel de poliacrilamida (SDS-PAGE)}

Os géis de eletroforese em poliacrilamida foram preparados conforme Laemmli (122) e Sambrook et al. (123), utilizando-se uma solução estoque de acrilamida 30\% (acrilamida $29 \%$ (p/v), N,N'-metilenobisacrilamida 1\% (p/v)), tampão do gel de empilhamento (Tris HCl 0,5 M pH 6,8, SDS 0,1\% (p/v)) ou tampão do gel de separação (Tris HCl 1,5 M pH 8,8, SDS $0,1 \%(\mathrm{p} / \mathrm{v}))$, persulfato de amônio $10 \%(\mathrm{p} / \mathrm{v})$ e TEMED. Os géis de empilhamento foram feitos com concentração de $5 \%$ e os géis de separação foram feitos com concentrações entre 12 e $15 \%$ e espessura entre $1,0 \mathrm{~mm}$ e $1,5 \mathrm{~mm}$. As corridas foram realizadas em tampão de eletroforese (Tris $\mathrm{HCl} 25 \mathrm{mM}$ pH 8,3, glicina $192 \mathrm{mM}$, SDS $0,1 \%(\mathrm{p} / \mathrm{v})$ ), sob voltagem de 
$120 \mathrm{~V}$, em temperatura ambiente. Os géis foram corados utilizando se corante Coomassie Brilliant Blue (ácido acético glacial 10\%, etanol 45\%, azul de Coomassie R250 0,25\%) ou transferidos para membrana de PVDF.

Em eletroforeses em condições redutoras, foi utilizado tampão de amostra $5 \mathrm{x}$ com agente redutor (Tris $\mathrm{HCl} 50 \mathrm{mM}$ pH 6,8, azul de bromofenol 0,1\% (p/v), glicerol 10\% (v/v), SDS $2 \%(\mathrm{p} / \mathrm{v}), \beta$-mercaptoetanol $100 \mathrm{mM}$ ) e aquecimento da amostra a $96{ }^{\circ} \mathrm{C}$ por 10 minutos. Em eletroforeses em condições não redutoras, o tampão não continha agente redutor (Tris $\mathrm{HCl} 50 \mathrm{mM}$ pH 6,8, azul de bromofenol 0,1\% (p/v), glicerol 10\% (v/v), SDS 2\% (p/v)) e a amostra foi aplicada sem aquecimento.

\subsection{Análises in silico das características das proteínas selecionadas}

A conservação dos genes foi avaliada através da análise comparativa das seqüências de aminoácidos preditas com auxílio do algoritmo BLASTP (http://blast.ncbi.nlm.nih.gov/) $(124,125)$. A presença de domínios comuns a outras proteínas foi avaliada com auxílio dos programas SMART (http://smart.embl-heidelberg.de/) (126), Pfam (http://www.sanger.ac.uk/) (127) e Conserved Domains (http://www.ncbi.nlm.nih.gov/Structure/cdd/wrpsb.cgi), (128, 129).

As análises de predição de localização celular foram realizadas com o auxílio do programa PSORTb versões 2.0.4 e 3.0.2 (http://www.psort.org/) (130, 131). A presença de sinal de clivagem ou lipidação foi avaliada com auxílio do programa SignalIP (http://www.cbs.dtu.dk/services/SignalP/) (132-134). O programa PyMOL (http://www.pymol.org/) foi utilizado para modelagem e visualização de proteínas em 3D.

\subsection{Seleção de genes candidatos contra leptospirose}

Como já mencionado anteriormente na introdução, foi realizado uma análise do genoma da Leptospira interrogans sorovar Copenhageni (número de acesso do GenBank AE016823) e, com o auxílio de ferramentas de bioinformática disponíveis em servidores de rede públicos, foram selecionados 12 genes candidatos vacinais para este projeto (lic10881, lic20087, lic11211, lic10544, lic10291, lic13435, lic11399, lic10642, lic10359, lic12558, lic10995 e lic10468). Estes genes foram selecionados por codificarem proteínas hipotéticas 
(com função desconhecida) e por possuírem seqüência sinal, indicando que são proteínas secretadas ou que são proteínas da membrana externa.

O fragmento carboxi-terminal da proteína LytM de Staphylococcus aureus foi selecionado para clonar e expressar para usarmos como controle em ensaios enzimáticos (135). O fragmento carboxi-terminal da proteína LigA de Leptospira interrogans sorovar Copenhageni também foi selecionado para utilizarmos como controle em alguns experimentos (136).

\subsection{Desenho de iniciadores específicos para PCR}

Os oligonucleotídeos iniciadores (primers) para obtenção de produtos de PCR das respectivas seqüências selecionadas foram desenhados utilizando o programa Generunner (Hastings Software) e seqüências flanqueadoras ou, sítios de restrição para o vetor de expressão pAE foram inseridos nas extremidades de ambos os primers (forward e reverse).

\subsection{Obtenção e cultivo de cepas de Leptospira virulentas e não virulentas}

As linhagens de Leptospira utilizadas neste trabalho foram obtidas do Laboratório de Zoonoses Bacterianas da Faculdade de Medicina Veterinária e Zootecnia da Universidade de São Paulo (FMVZ-USP).

A obtenção de leptospiras virulentas foi realizada conforme o protocolo descrito por Nally et. al (48). Basicamente, hamsters recém desmamados foram injetados intraperitonialmente com $500 \mu \mathrm{L}$ de cultura de L. interrogans sorovar Copenhageni cepa L1130 virulentas na diluição de $10^{8}$ células $/ \mathrm{mL}$. Esses animais foram acompanhados diariamente até o aparecimento dos sintomas da doença, como perda de peso e mobilidade, que ocorrem em aproximadamente 5 dias após a infecção, e foram posteriormente sacrificados em câmara de $\mathrm{CO}_{2}$. Os rins e fígados desses animais foram retirados, macerados e cultivados em meio EMJH (Difco) semi-sólido, enriquecido com 10\% de soro de coelho com L-asparagina, piruvato de sódio, cloreto de cálcio e cloreto de magnésio e 0,2\% de ágar, a uma temperatura de $28{ }^{\circ} \mathrm{C}$, e sub-cultivados em meio EMJH líquido (sem ágar), por no máximo duas passagens para a manutenção da virulência das leptospiras (10 a 15 dias). Para a obtenção de leptospiras de passagens definidas (número de vezes em que a cultura bacteriana foi repicada), a cultura 
de leptospiras em meio EMJH líquido mencionada anteriormente (primeira passagem) foi repicada sucessivamente, por exemplo, o repique da cultura de primeira passagem deu origem à cultura de segunda passagem e, o repique desta cultura (segunda passagem) deu origem à cultura de terceira passagem e assim por diante.

As culturas de leptospiras de variados sorovares não virulentos foram mantidas em meio EMJH líquido (sem ágar). A cultura foi mantida a uma temperatura de $28{ }^{\circ} \mathrm{C}$ sem agitação, por cerca de 7 a 10 dias, período em que o cultivo tende a se encontrar em fase estacionária. Foram cultivadas 5 espécies patogênicas (L. interrogans, L. santarosai, L. borgpetersenii, L. kirshneri e L. noguchii) e uma espécie saprofítica (L. biflexa). A espécie, sorogrupo e sorovar das cepas cultivadas estão descritas na te bela 1 .

Tabela 1 - Cepas de Leptospira cultivadas

\begin{tabular}{lll}
\hline Espécie & Sorogrupo & Sorovar \\
\hline & Australis & Bratislava \\
& Autumnalis & Autumnalis \\
& Canicola & Canicola \\
L. interrogans & Icterohaemorrhagiae & Copenhageni \\
& Icterohaemorrhagiae & Icterohaemorrhagiae \\
& Pomona & Pomona \\
& Pyrogenes & Pyrogenes \\
& Serjroe & Hardjo \\
\hline \multirow{2}{*}{ borgpetersenii } & Ballum & Castellonis \\
& Javanica & Javanica \\
\hline \multirow{2}{*}{ L. santarosai } & Bataviae & Bataviae \\
\hline L. kirshneri & Shermani & Shermani \\
\hline L. noguchii & Grippotyphosa & Grippotyphosa \\
\hline L. biflexa & Cynopteri & Cynopteri \\
\hline
\end{tabular}

\subsection{Obtenção e cultivo de Staphylococcus aureus}

A cepa 469/10 de Staphylococcus aureus foi gentilmente cedida pela pesquisadora Silvia Regina dos Santos do Hospital Universitário da Universidade de São Paulo (HU-USP). As bactérias foram extraídas de uma placa ágar sangue (NewProv, enriquecido com $5 \%$ de sangue de carneiro) e cultivadas em meio THY (Todd Hewitt Broth - Difco, enriquecido com $0,5 \%$ de extrato de levedura) a $37^{\circ} \mathrm{C}$ por 16 horas. 


\subsection{Soros de pacientes com leptospirose}

Os soros de pacientes diagnosticados com leptospirose foram obtidos da coleção de soros sob responsabilidade da Dra. Eliete Caló Romero do Instituto Adolfo Lutz, São Paulo, Brasil.

\subsection{Extração de DNA genômico de Leptospira}

Os DNAs genômicos das culturas mencionadas anteriormente foram obtidos com uma solução de guanidina-detergente (DNAzol ${ }^{\circledR}$ Reagent, Invitrogen), de acordo com as instruções do fabricante.

\subsection{Extração de RNA de leptospira}

Para a extração de RNA, foram utilizados $20 \mathrm{~mL}$ de cultura de cepas de Leptospira interrogans sorovar Pomona, Canicola, Copenhageni e Leptospira biflexa sorovar Patoc nas mesmas condições de cultivo descritas previamente. As culturas foram centrifugadas $(4600 \mathrm{x}$ g por $30 \mathrm{~min}$, a $4^{\circ} \mathrm{C}$ ), e o sobrenadante descartado. Os sedimentos bacterianos foram lavados duas vezes em PBS 1x. A extração de RNA foi feita utilizando-se método do ácido guanidino tiocianato fenol-clorofórmio, utilizando-se o reagente TRIzol ${ }^{\circledR}$ (Invitrogen), de acordo com as instruções do fabricante. Um micrograma de RNA de cada amostra foi tratado com $1 \mathrm{U}$ de DNAse I (Invitrogen) por $15 \mathrm{~min}$ em temperatura ambiente. A DNAse I foi inativada através da adição de $1 \mu \mathrm{L}$ de uma solução de $25 \mathrm{mM}$ EDTA, seguindo por uma incubação a $65^{\circ} \mathrm{C}$ por 10 min. A integridade dos RNAs extraídos foram analisadas em gel de agarose $1 \%$ contendo brometo de etídeo (123).

\subsection{Reação em cadeia da polimerase (PCR)}

Os oligonucleotídeos iniciadores foram ressuspensos em água MilliQ para concentração final entre 3,2 a $10 \mu \mathrm{M}$. Os oligonucleotídeos utilizados nas amplificações de DNA e seqüenciamentos estão nas tabelas 2 e 3. 
Tabela 2 - Oligonucleotídeos utilizados no seqüenciamento de plasmídeos pGem-T Easy e pAE

\begin{tabular}{cl}
\hline Oligonucleotídeos & Seqüência $\mathbf{5}^{\prime}-\mathbf{3}$ \\
\hline M13F & GTTTTCCCAGTCACGAC \\
\hline M13R & CAGGAAACAGCTATGAC \\
\hline T7 & TAATACGACTCACTATAGGG \\
\hline PrSetRev & ATGCTAGTTATTGCTCAGCGGTGG \\
\hline
\end{tabular}

Tabela 3 - Oligonucleotídeos empregados na amplificação de fragmentos de DNA por PCR

\begin{tabular}{|c|c|c|c|}
\hline $\begin{array}{l}\text { Lócus / } \\
\text { gene }\end{array}$ & Iniciadores $\left(5^{\prime} \rightarrow 3^{\prime}\right)$ * & $\begin{array}{c}\text { Tamanho do } \\
\text { fragmento } \\
\text { amplificado } \\
\text { (pb) }\end{array}$ & $\begin{array}{c}\text { Massa molecular } \\
\text { esperada da } \\
\text { proteína } \\
\text { recombinante } \\
\text { (KDa) }\end{array}$ \\
\hline LIC20087 & $\begin{array}{l}\text { F: GGATCCGTAGAAAATCCTTCGTTCAG } \\
\text { R: AAGCTTTTACTTAGAAGAAGTTTCCG }\end{array}$ & 894 & 33,75 \\
\hline LIC10544 & $\begin{array}{l}\text { F: GGATCCGATTCTCAAAAATCAGATTC } \\
\text { R: CAGCTGTTATATTTTAACCGAAATCG }\end{array}$ & 1332 & 51,34 \\
\hline LIC11211 & $\begin{array}{l}\text { F: GGATCCCAAGAACAGAGAAAATCTACG } \\
\text { R: AAGCTTCTAATTCGTTTTAGAATCCTG }\end{array}$ & 1029 & 38,84 \\
\hline LIC10291 & $\begin{array}{l}\text { F: GGATCCGATGAGTCCGAGAAAAAAACTTATTC } \\
\text { R: } \underline{\text { AAGCTTTTACTCTACGGTTGTAATTTC }}\end{array}$ & 456 & 17,3 \\
\hline LIC10881 & $\begin{array}{l}\text { F: CTCGAGGGCACCTTATGGGCAAAGGCTTCTC } \\
\text { R: } \text { AAGCTTTCATTCTCTTGATTTATCGTAG }\end{array}$ & 1602 & 60.42 \\
\hline LIC13435 & $\begin{array}{l}\text { F: GGATCCCAAACTTTGGATCAGAAC } \\
\text { R: AAGCTTTTAATTAGATGGATCTGTTTT }\end{array}$ & 537 & 20,2 \\
\hline LIC11399 & $\begin{array}{l}\text { F: CTCGAGGCCCCAATCGCCTACGGAAATTTA } \\
\text { R: AAGCTTTCAATCCACTCCGTTTCTTTTG }\end{array}$ & 1089 & 41 \\
\hline C-terminal & F: CTCGAGGGTTATTCGTTTCCAGTTC & 615 & 22,6 \\
\hline LIC10642 & $\begin{array}{l}\text { F: GGATCCGATACAATCATCTTAAAAGACGGCC } \\
\text { R: } \underline{\text { AAGCTTTTATAACTTAAATCCGGTTCC }}\end{array}$ & 906 & 34,4 \\
\hline LIC10359 & $\begin{array}{l}\text { F: GGATCCGATCCTGGAAGAGATAGACTAG } \\
\text { R: AAGCTTTTATTCCTTTTCGTTCAGAG }\end{array}$ & 555 & 19,9 \\
\hline LIC10468 & $\begin{array}{l}\text { F: GGATCCTTCGTTTCTCGAAAACTGATTTTTATAGC } \\
\text { R: } \underline{\text { AAGCTTTCATTGGATAAAATCTCGGATTAG }}\end{array}$ & 753 & 27,9 \\
\hline LIC12558 & $\begin{array}{l}\text { F: GGATCCCAAACTAAAAACGCTGATAAACAAG } \\
\text { R: AAGCTTTTATCCGTTAGACGAAACCCATAT }\end{array}$ & 654 & 25,2 \\
\hline LIC10995 & $\begin{array}{l}\text { F: GGATCCCAAACTTTGGATCAGAAC } \\
\text { R: } \text { AAGCTTTTAAAAAAGAGAAAGAAAAAG }\end{array}$ & 1068 & 39 \\
\hline ctLigA & $\begin{array}{l}\text { F: CTCGAGGGTTACCAAGGACAAGCTTAC } \\
\text { R: AAGCTTTTATGGCTCCGTTTTAATAGAGGC }\end{array}$ & 1266 & 44,2 \\
\hline etLytM & $\begin{array}{l}\text { F: CTCGAGAAAGCGACAGCTAGT GGTCAT G } \\
\text { R: } \text { AAGTTTTATCTACTTTGTAAGTATGACG }\end{array}$ & 456 & 16,2 \\
\hline
\end{tabular}

* A sequiência da enzima de restrição utilizada está sublinhada

As reações de PCR foram realizadas de acordo com a temperatura de anelamento de cada oligo utilizado e comprimento do fragmento esperado, utilizando-se como molde o DNA 
genômico de L. interrogans sorovar Copenhageni (linhagem Fiocruz L1-130). As amplificações foram realizadas em volume de $50 \mu \mathrm{L}$ contendo $0,5 \mu \mathrm{M}$ de cada oligonucleotídeo, 0,4 mM de cada dNTP, cerca de $60 \eta \mathrm{g}$ de DNA genômico, $1 \mu \mathrm{L}$ de Platinum $P f x$ DNA polimerase $400 \mathrm{U} / \mu \mathrm{L}$ (Invitrogen), tampão da $P f x$ DNA polimerase 1x (fornecido pelo fabricante pronto para uso) e $1 \mathrm{mM} \mathrm{MgSO}_{4}$.

As reações foram realizadas utilizando-se termociclador (Perkin-Elmer). As características dos ciclos foram otimizadas para cada produto. As etapas 2 a 4 foram repetidas por 25 a 30 ciclos, dependendo do produto desejado. As etapas de desnaturação, anelamento e amplificação do DNA estão na tabela 4.

Os produtos de PCR foram submetidos a uma migração eletroforética em gel de agarose (123) para análise.

Tabela 4 - Ciclos de amplificação de fragmentos de DNA por PCR

\begin{tabular}{lcc}
\hline & Temperatura & Tempo \\
\hline 1. Desnaturação inicial & $95{ }^{\circ} \mathrm{C}$ & 3 minutos \\
\hline 2. Desnaturação & $95{ }^{\circ} \mathrm{C}$ & 30 segundos \\
\hline 3. Anelamento & $48-58^{\circ} \mathrm{C}$ & 30 segundos \\
\hline 4. Amplificação & $72{ }^{\circ} \mathrm{C}$ & 3 minutos \\
\hline 5. Amplificação final & $72{ }^{\circ} \mathrm{C}$ & 5 minutos \\
\hline
\end{tabular}

\subsection{Transcrição reversa e RT-PCR (Transcriptase reversa seguida de reação em cadeia da polimerase)}

Os RNAs foram reversamente transcritos para obtenção do DNA complementar (cDNA), utilizando-se kit comercial SuperScript TM III First-Strand Synthesis System for RTPCR (Invitrogen) de acordo com as instruções do fabricante. Para a RT-PCR, um décimo do produto da transcrição reversa foi amplificado em uma reação de PCR conforme descrito acima. Os produtos de RT-PCR foram submetidos a uma migração eletroforética em gel de agarose para análise (123). 


\subsection{Vetores recombinantes utilizados}

\subsubsection{Vetor de clonagem}

O vetor pGem-T Easy (Promega) (figura 5) possui origem de replicação pUC ori que permite a propagação em bactérias, um gene que confere resistência à ampicilina $(A m p R)$ e o gene para metabolismo de lactose (lacZ) que, quando rompido pela presença do inserto, permite a seleção de clones positivos por formação de colônias brancas em presença de X-gal. Este vetor é fornecido pelo fabricante na forma linear, preparado a partir da digestão do plasmídeo pGEM-5Zf(+) com a enzima de restrição $E c o R V$, e posterior adição de timinas nas extremidades 3'. As timinas livres possibilitam a ligação de produtos de PCR, já que esses possuem adenosinas livres nas extremidades 3', adicionadas pela atividade transferase da enzima Taq polimerase utilizada na reação sem necessidade de digestão prévia do fragmento ou do vetor.

Figura 5 - Mapa do vetor pGEM-T-Easy (Promega) de clonagem. F1 ori: origem; lacZ: gene para metabolismo de lactose ( $\beta$-Galactosidase); AmpR: gene de resistência à ampicilina.

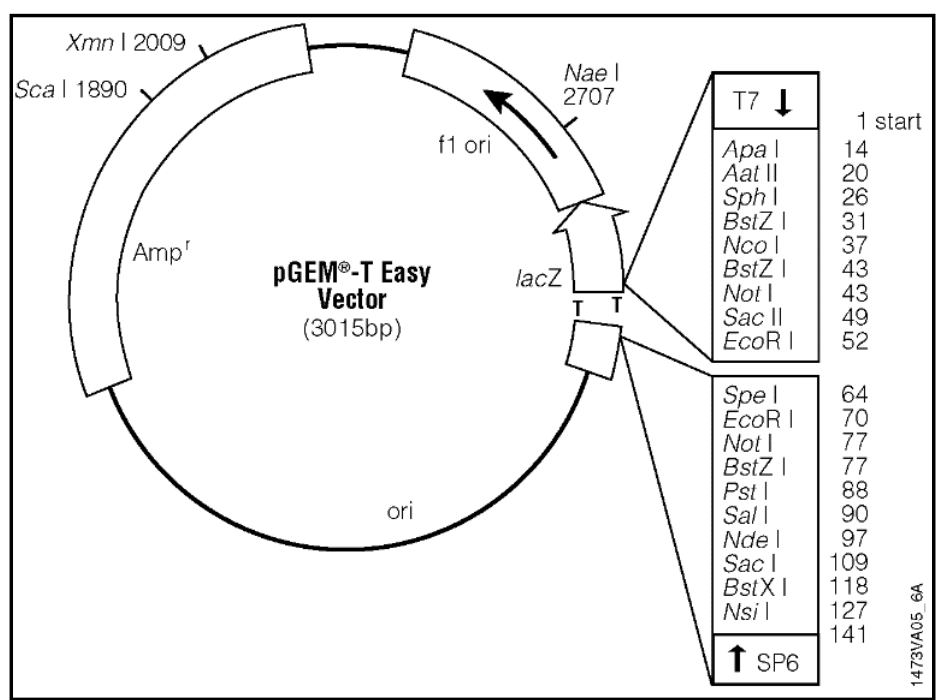

\subsubsection{Vetor de expressão}

$\mathrm{O}$ vetor de expressão em modelo procarioto empregado nas clonagens foi o pAE (137), construído a partir dos plasmídeos pRSET-A (Invitrogen) e pET3-His (138). O vetor pAE (Figura 6) é constituído pelo promotor de alta cópia do fago T7 (pT7), sítio de ligação ao ribossomo (RBS), sítios de múltiplas clonagens (MCS), terminador de transcrição (T7 term.), 
e seqüência codificadora para $\beta$ - lactamase que confere resistência ao antimicrobiano ampicilina (AmpR). Na extremidade amino-terminal do inserto a ser clonado, há uma região codificadora para 6 resíduos de histidina na proteína heteróloga, o que permite a purificação da mesma por cromatografia de afinidade a metais bivalentes (137).

Figura 6 - Representação esquemática do vetor de expressão pAE. O vetor pAE adiciona uma sequiência contendo seis resíduos de histidinas na região amino-terminal da proteína recombinante.

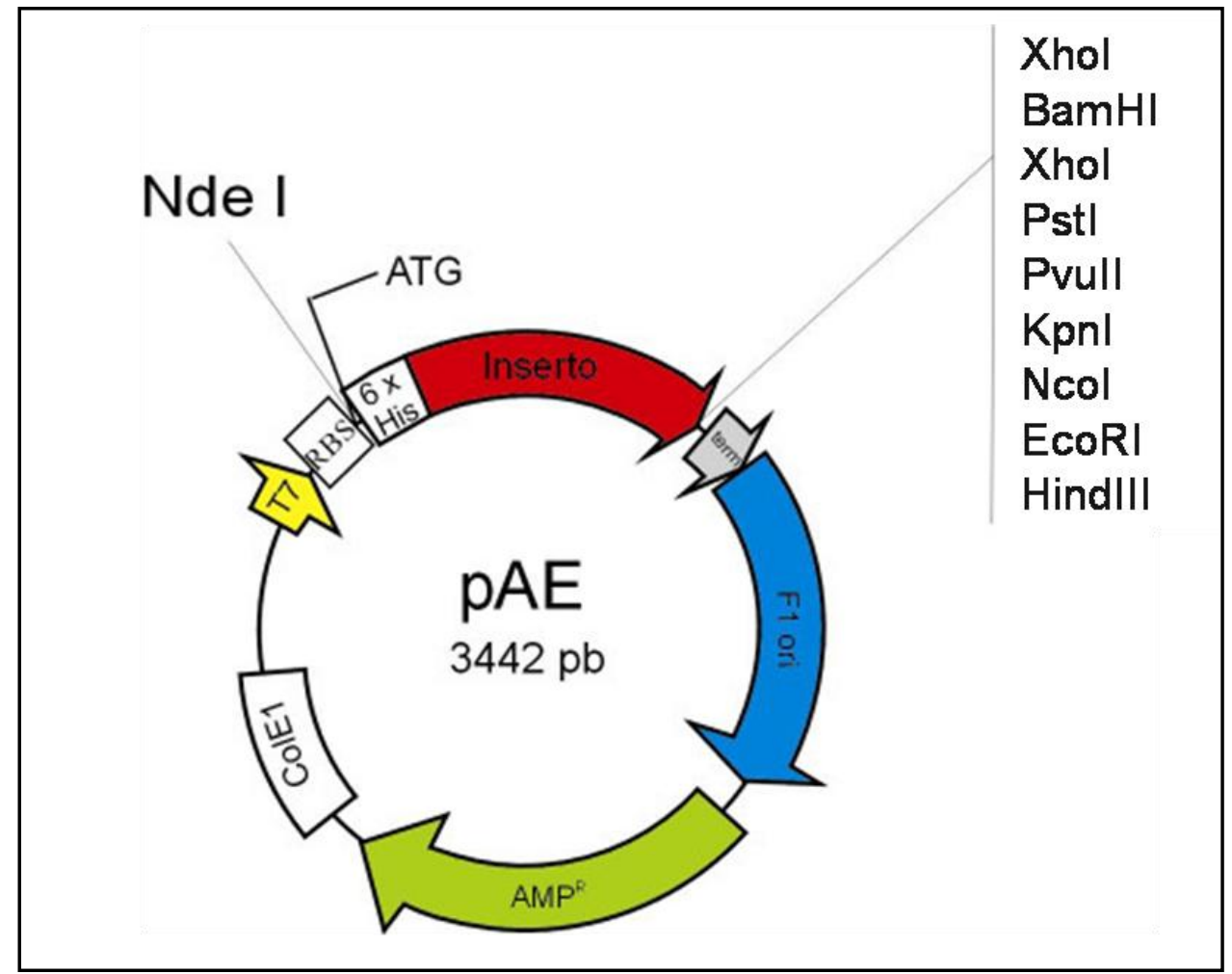

\subsection{Subclonagem dos produtos de PCR}

Para subclonagem, os produtos de PCR foram ligados no vetor pGEM-T easy (Promega). Para a reação de ligação dos insertos ao vetor de subclonagem, os produtos de PCR foram submetidos a uma migração eletroforética em um gel de agarose 1\% (123). Após a migração, as bandas referentes aos fragmentos amplificados foram excisadas e purificadas do gel utilizando-se o kit "GFX ${ }^{\mathrm{TM}}$ Gel Band Purification" (GE Healthcare). Os fragmentos de DNA purificados foram, quando necessário, submetidos a uma reação de adenilação (descrito a baixo), pois, o vetor pGEM-T easy, no qual foram ligados, é fornecido pelo fabricante na forma linear, com um resíduo de timina nas extremidades 3 '. 


\subsubsection{Reação de adenilação}

Para cada reação de $50 \mu \mathrm{L}$ foram utilizados cerca de $50 \eta \mathrm{g}$ do inserto purificado, 1 $\mathrm{mM} \mathrm{MgCl}_{2}$, dATP 0,2 mM, 1 unidades (U) de Taq polimerase (Invitrogem) em $\mathrm{H}_{2} \mathrm{O}$. As reações de adenilação foram realizadas a $72{ }^{\circ} \mathrm{C}$ por 30 minutos, utilizando-se um termociclador.

\subsubsection{Reação de ligação}

Cerca de $50 \eta \mathrm{g}$ de cada fragmento submetido à adenilação foi incubado com 25 ๆg do vetor pGEM-T easy, $1 \mu \mathrm{L}$ de $\mathrm{T}_{4}$ DNA ligase $400 \mathrm{U} / \mu \mathrm{L}$ na presença da solução tampão fornecida pelo fabricante da enzima, num volume total de $20 \mu \mathrm{L}$ por 16 horas a $16{ }^{\circ} \mathrm{C}$.

\subsection{Transformação de bactérias competentes}

Foram adicionados a $50 \mu \mathrm{L}$ de bactérias E. coli DH5 $\alpha$ quimiocompetentes (competência por $\mathrm{Ca}^{2+}$ ) $2 \mu \mathrm{L}$ do produto da reação de ligação. A mistura foi incubada em gelo por 30 minutos e em seguida submetida a choque térmico de $42{ }^{\circ} \mathrm{C}$ por 2 minutos seguidos por 5 minutos de incubação em gelo. Após essa incubação adicionou-se $400 \mu \mathrm{L}$ de meio 2 YT e deixou-se incubando a $37{ }^{\circ} \mathrm{C}$ por 1 hora. $\mathrm{O}$ volume total dessa mistura foi dividido e plaqueado em meio sólido (2YT-ágar), contendo $100 \mu \mathrm{g} / \mathrm{mL}$ de ampicilina e incubados por 16 horas a $37^{\circ} \mathrm{C}$.

\subsection{Análise de plasmídeos através de extração com fenol-clorofórmio}

O método de fenol : clorofórmio (139) foi usado para verificar a presença e o tamanho de fragmentos clonados em plasmídeos diretamente de culturas de bactérias.

As colônias resistentes a ampicilina e uma colônia com vetor vazio (controle negativo) foram inoculados em $5 \mathrm{~mL}$ de meio de $2 \mathrm{YT}$ contendo ampicilina e incubados por 16 horas a $37^{\circ} \mathrm{C}$. Uma alíquota de $400 \mu \mathrm{L}$ foi centrifugada por 2 minutos a $13.400 \mathrm{x}$ g e o sobrenadante foi descartado e adicionou-se ao precipitado bacteriano $100 \mu \mathrm{L}$ de Ficoll Dye 2x (azul de bromofenol 0,05\% (p/v), xileno cianol FF 0,1\% (p/v), glicerol 10\% (v/v)), e $38 \mu \mathrm{L}$ de uma 
solução 1:1 de fenol: clorofórmio (V/V) (fenol pH 7,6 50\% (v/v), clorofórmio 50\% (v/v)). A mistura foi agitada por 1 minuto e centrifugada por 1 minuto a 13.400 x g. Foram aplicados $20 \mu \mathrm{L}$ do sobrenadante dessa mistura contendo DNA genômico e plasmidial em um gel de agarose $1 \%$ (123) para análise.

A banda do plasmídeo do controle negativo (plasmídeo sem inserto) deve ter maior mobilidade que os plasmídeos dos clones positivos, devido à diferença de massa molecular entre eles. Portanto, os clones que migraram menos em relação ao controle negativo, foram selecionados para serem purificados.

\subsection{Purificação de plasmídeos}

Os cultivos selecionados utilizados na pesquisa de clones positivos foram utilizados para purificação dos plasmídeos com o kit "Promega Wizard Plus Miniprep”. Foi utilizado 3 $\mathrm{mL}$ de cada meio de cultivo selecionado e as etapas subseqüentes foram realizadas conforme as instruções do fabricante. Após a purificação dos plasmídeos os mesmos foram seqüenciados usando os primers específicos para pGEM-T easy pelo método de terminação de cadeia (140), no seqüenciador de DNA ABI 3100 (Applied Biosystems do Brasil).

\subsection{Clonagem em vetor de expressão}

Para a clonagem dos inserto no vetor pAE, foi necessário submeter os plasmídeos purificados e o vetor pAE vazio à digestão com as respectivas enzimas de restrição que "flanqueiam" os insertos de interesse. Os produtos das digestões com as endonucleases foram submetidos à eletroforese em gel de agarose 1\%, para excisar a banda relativa ao fragmento linearizado com o tamanho esperado. Essas bandas foram purificadas e os respectivos fragmentos foram ligados ao vetor de clonagem da mesma maneira descrita anteriormente. Os produtos das ligações foram transformados em E. coli DH5 $\alpha$ quimiocompetentes e submetidos à seleção de clones positivos e seqüenciados com primers específicos para pAE conforme descrito anteriormente. 


\subsection{Indução protéica em bactérias de expressão e purificação}

Após as análises por seqüenciamento, os genes corretamente inseridos nos vetores de expressão foram transformados nas linhagens de bactérias de expressão disponível em nosso laboratório.

A expressão das proteínas foram avaliadas nas bactérias de expressão Escherichia coli BL21 SI, Escherichia coli Star pLysS (Invitrogen) e Escherichia coli (DE3) C43 (Avidis).

As bactérias que expressaram a proteína recombinante de interesse foram lisadas por French Pressure ${ }^{\circledR}$. O lisado foi centrifugado para separar a fração solúvel e insolúvel de proteínas. No caso da expressão da proteína de interesse na fração insolúvel (em corpúsculos de inclusão), foi necessário realizar a solubilização e renaturação (refolding) da proteína, para depois ser purificada por cromatografia em coluna de afinidade a metais bivalentes.

Os corpúsculos de inclusão obtidos do precipitado da suspensão bacteriana após lise celular e centrifugação, foram lavados primeiramente com $20 \mathrm{ml}$ de uma solução contendo 200 mM Tris- $\mathrm{HCl}$, pH 8.0, 5 mM $\beta$-mercaptoetanol e $1 \mathrm{M}$ uréia (solução $1 \mathrm{M}$ uréia). A seguir, os corpúsculos de inclusão foram solubilizados por 16 horas em $20 \mathrm{ml}$ de uma solução contendo $200 \mathrm{mM}$ Tris- $\mathrm{HCl}, 5 \mathrm{mM} \beta$-mercaptoetanol, $8 \mathrm{M}$ uréia (solução $8 \mathrm{M}$ uréia). Para a renaturação protéica, foi utilizada uma solução de 2 litros contendo $200 \mathrm{mM}$ de Tris HCl, pH 8.0 , onde os $20 \mathrm{ml}$ da solução $8 \mathrm{M}$ uréia foi gotejada lentamente sob agitação. Após o gotejamento da solução, os 2 litros de solução de renaturação ficaram durante uma noite sob agitação. Uma coluna (GE-Healthcare) com $1 \mathrm{~cm}$ de diâmetro, contendo $5 \mathrm{~mL}$ de resina com afinidade a metais bivalentes foi preparada com uma solução $300 \mathrm{mM} \mathrm{NiSO}_{4}$, lavada com 10 $\mathrm{ml}$ de água para a remoção do excesso da solução de níquel e posteriormente equilibrada com o tampão de equilíbrio (tampão de renaturação protéica, $200 \mathrm{mM}$ Tris $\mathrm{HCl}, \mathrm{pH}$ 8.0). A solução foi então adsorvida pela coluna, com o auxílio da bomba peristáltica, com fluxo de $3,5 \mathrm{ml} / \mathrm{min}$. A resina, com a proteína recombinante adsorvida, foi submetida a lavagens e eluição com soluções de concentração crescente de imidazol (5 mM, 20 mM, 40 mM, 60 mM e $1 \mathrm{M}$ em $200 \mathrm{mM}$ de Tris $\mathrm{HCl}, \mathrm{pH}$ 8.0). A fração contendo a proteína purificada foi dialisada em 4 litros de tampão $200 \mathrm{mM}$ Tris $\mathrm{HCl}, \mathrm{pH} 8.0$, a $4^{\circ} \mathrm{C}$ por 12 horas sob agitação. Após a diálise, a amostra foi fracionada em alíquotas de $1 \mathrm{~mL}$ e congelada a $-20{ }^{\circ} \mathrm{C}$.

Para as proteínas expressas na fração solúvel do lisado da bactéria de expressão, o sobrenadante do lisado foi filtrado e diretamente aplicado na coluna de cromatografia com resina de afinidade a metais bivalentes, com o auxílio de uma bomba peristáltica, porém, com um fluxo de $1 \mathrm{~mL} / \mathrm{min}$. Após a adsorsão da proteína pela resina de afinidade a metais 
bivalentes, a purificação da proteína procedeu conforme mencionado anteriormente. A concentração de proteína total foi estimada por densitometria a partir de um gel de SDSPAGE e pelo método de Bradford (141). A quantidade relativa de proteína foi calculada em relação a uma curva-padrão estabelecida, com quantidades crescentes de BSA.

\subsection{Ensaio de dicroísmo circular}

Espectros de dicroísmo circular (CD) foram captados em espectropolarímetro Jasco modelo J-810 (“circular dichroism system”, Japan Spectroscopic, Tokyo, Japan). As amostras de proteínas foram diluídas para uma concentração final de $10 \mu \mathrm{M}$ dialisadas contra tampão fosfato $10 \mathrm{mM}(\mathrm{pH} \mathrm{7,4).} \mathrm{Foram} \mathrm{mensurados} \mathrm{comprimentos} \mathrm{de} \mathrm{onda} \mathrm{de} 190$ a $260 \mathrm{~nm}$, utilizando-se cubetas de quartzo com $1 \mathrm{~mm}$ de caminho óptico, por nove vezes consecutivas, a temperatura de $20{ }^{\circ} \mathrm{C}$, em intervalo de $0,5 \mathrm{em} 0,5 \mathrm{~nm}$, e velocidade de $50 \mathrm{~nm} / \mathrm{min}$. Os espectros de $\mathrm{CD}$ foram expressos em termos de elipticidade molar residual:

$$
[\Phi]=\Phi(\mathrm{mdeg}) / 10 \times \mathrm{C}(\mathrm{M}) \times \mathrm{I}(\mathrm{cm})
$$

Onde $\Phi$ é elipticidade, C é a concentração da proteína e L é o caminho ótico (142).

Os dados gerados pelo CD foram interpretados com o auxílio do algoritmo CONTIN (http://s-provencher.com/pages/contin-cd.shtml)(143), e comparado com a predição de estrutura secundária teórica, gerado com o auxílio do programa público GOR (GOR IV Secondary Structure Prediction Method http://npsa-pbil.ibcp.fr/cgibin/npsa_automat.pl?page=npsa_gor4.html) $(144)$.

\subsection{Seqüenciamento de proteína}

O seqüenciamento da porção amino-terminal da proteína foi realizado conforme descrito por Edman (145), utilizando o seqüenciador de proteína automatizado PPSQ-21 Shimadzu (Japão), de acordo com as instruções do fabricante. O seqüenciamento foi realizado no Laboratório de Bioquímica e Biofísica do Instituto Butantan, Brasil. 


\subsection{Imunização de camundongos para obtenção de soro hiperimune}

As proteínas recombinantes purificadas foram utilizadas para induzir a produção de anticorpos em camundongos. Grupos de 5 camundongos Balb-C fêmeas, foram imunizados intraperitonealmente com $10 \mu \mathrm{g}$ de proteína na presença de $100 \mu \mathrm{g}$ de adjuvante hidróxido de alumínio (proporção de $10 \mu \mathrm{g}$ de íon $\mathrm{Al}^{3+}$ para cada $1 \mu \mathrm{g}$ de proteína recombinante). As imunizações foram realizadas por pelo menos quatro semanas, com aplicação de doses semanais. Os animais foram sangrados pelo plexo retrorbital e o sangue coletado foi mantido a $37{ }^{\circ} \mathrm{C}$ por 30 minutos e, posteriormente, centrifugado a 800 x g por 15 minutos. Após a centrifugação o sobrenadante foi coletado e armazenado a $-20{ }^{\circ} \mathrm{C}$.

\subsection{Titulação dos anticorpos policlonais}

A análise da especificidade e título dos anticorpos contra as respectivas proteínas recombinantes foi monitorada por ELISA (Enzyme-Linked Immnosorbent Assay). Para adsorção dos antígenos, placas de microtítulo (Maxisorp-NUNC) foram expostas a $100 \mu \mathrm{L} /$ poço de solução tampão cabonato / bicarbonato $0,05 \mathrm{M}(\mathrm{pH} 9,6)$ contendo $1 \mu \mathrm{g}$ de proteína recombinante purificada e incubadas por 16 horas a $4{ }^{\circ} \mathrm{C}$. As placas foram lavadas 3 vezes com tampão PBS acrescido de Tween-20 0,05\% (PBS-T) e bloqueadas com $200 \mu \mathrm{L} /$ poço de PBS-T contendo leite desnatado em pó $10 \%$ por 1 hora a $37{ }^{\circ} \mathrm{C}$. Após essa encubação, as placas foram lavadas 3 vezes com PBS-T $0,05 \%$.

Diluições seriadas dos soros foram preparadas em $100 \mu \mathrm{L} /$ poço de tampão PBS-T 0,05\% acrescido de BSA $1 \%$ e incubadas por 90 minutos a $37^{\circ} \mathrm{C}$. Após essa etapa, as placas foram lavadas 3 vezes com PBS-T 0,05\%. A seguir, foram adicionados $100 \mu \mathrm{L} /$ poço de PBS-T 0,05\% acrescido de BSA $1 \%$ contendo anticorpo anti-IgG de camundongo, conjugado com peroxidase (Sigma) gerado em cabra, em uma diluição de 1: 10.000 e incubado por 1 hora a $37^{\circ} \mathrm{C}$. Após essa incubação, as placas foram lavadas 3 vezes com PBS-T 0,05\%.

A reação foi desenvolvida com a adição de $100 \mu \mathrm{L}$ de solução de revelação OPD (8 mg de o-fenilenodiamina) em $20 \mathrm{~mL}$ de tampão citrato-fostato $0,2 \mathrm{M}$, pH 5,0 na presença de $10 \mu \mathrm{L}$ de $\mathrm{H}_{2} \mathrm{O}_{2} 30 \%$ ) e interrompida após 15 minutos pela adição de $50 \mu \mathrm{L}$ de $8 \mathrm{M} \mathrm{H}_{2} \mathrm{SO}_{4}$. A intensidade da absorbância foi analisada em espectrofotômetro a $492 \mathrm{~nm}$ em leitor de 
microplacas (Labsystems Uniscience Multiskan EX). O título de anticorpos foi considerado como a maior diluição do soro capaz de resultar em uma absorbância a $492 \mathrm{~nm}$ igual a 0,1.

\subsection{Adesão a componentes de matriz extracelular (MEC)}

Todas as macromoléculas incluindo as proteínas controle fetuína e BSA foram compradas da empresa Sigma Chemical Co. (St. Louis, Mo.). A Laminina I e colágeno tipo IV são derivados da membrana basal de sarcoma murino de Engelbreth-Holm-Swarm, a fibronectina celular é derivada de fibroblasto humano, enquanto que a fibronectina plasmática é isolada do plasma humano.

O ensaio de adesão a componentes de matriz extracelular foi realizado de acordo com Barbosa et al.(101). Brevemente, poços de uma placa de micro-poços foram revestidos com um micrograma de cada MEC, diluídos em $100 \mu \mathrm{L}$ de PBS, e incubados por, pelo menos, 16 horas a $4{ }^{\circ} \mathrm{C}$. A solução de revestimento foi então lavada 3 vezes com PBS-T $0,05 \%$ e os poços foram bloqueados com $200 \mu \mathrm{L}$ de BSA $1 \%$ em PBS por 2 horas a $37{ }^{\circ} \mathrm{C}$. Em seguida, 1 $\mu \mathrm{g}$ de cada proteína recombinante diluído em PBS foi adicionado aos poços, e estas foram incubadas por 90 minutos a $37^{\circ} \mathrm{C}$. Após a incubação, os poços foram lavados 6 vezes com PBS-T 0,05\% e incubados com o antisoro especifico da proteína de interesse, diluído em PBS (1:4000), por 1 hora a $37{ }^{\circ} \mathrm{C}$. A seguir, as placas foram lavadas 3 vezes com PBS-T 0,05\% e incubadas com o anti-IgG de camundongos conjugado a peroxidase diluídos em PBS (1:5000), por 1 hora a $37^{\circ} \mathrm{C}$. Após essa etapa, os poços foram lavados 3 vezes com PBS-T 0,05\% e revelados com a adição $100 \mu \mathrm{L}$ de uma solução contendo $8 \mathrm{mg}$ de o-fenilenodiamina (OPD) em $20 \mathrm{~mL}$ de tampão citrato-fostato $0,2 \mathrm{M}$, pH 5,0 na presença de $10 \mu \mathrm{L}$ de $\mathrm{H}_{2} \mathrm{O}_{2}$ e interrompida após 20 minutos pela adição de $50 \mu \mathrm{L}$ de $8 \mathrm{M} \mathrm{H}_{2} \mathrm{SO}_{4}$. A absorbância a $492 \mathrm{~nm}$ foi determinada em um leitor de microplacas (Labsystems Uniscience Multiskan EX). Os experimentos foram realizados 3 vezes, todos em triplicata.

Para as análises estatísticas, a ligação das proteínas recombinantes aos componentes de matriz celular foi comparada às respectivas ligações à fetuína (controle negativo) através do teste $t$ de Student. 


\subsection{Obtenção dos extratos protéicos totais de cultura de leptospira}

A cultura de leptospiras, ao atingirem uma concentração celular de aproximadamente $10^{8}$ células / mL contadas em câmara de Ptroff-Hausser em microscópio de campo escuro, foram centrifugadas $\left(12.800 \mathrm{x} \mathrm{g}, 4^{\circ} \mathrm{C}, 30 \mathrm{~min}\right)$, e os sedimentos bacterianos foram lavados por 2 vezes com solução PBS 1x. Posteriormente, cada sedimento bacteriano foi ressuspendido em solução de lise (7 M uréia, 10\% SDS), na proporção de $5 \mu \mathrm{L}$ por miligrama de bactérias. A lise celular foi feita por agitação em vortex, seguido por sucessivas passagens em seringa de $1 \mathrm{~mL}$. Em seguida, fez-se uma centrifugação a 20.000 x g por 10 min para a retirada do sedimento celular, e o sobrenadante foi coletado e armazenado a $-80{ }^{\circ} \mathrm{C}$.

\subsection{Western blot}

O procedimento usado é basicamente o mesmo descrito por Towbin et. al (146). Alíquotas do preparado protéico foram submetidas à eletroforese em gel de poliacrilamida SDS-PAGE 12 ou 15\%, e imediatamente transferidas, para uma membrana de nitrocelulose (Hybond ECL, GE Healthcare) utilizando-se um aparato tipo sanduíche (Biorad), submersa em tampão de transferência (Tris-Glicina acrescido de 1,85 \% de SDS). Após a transferência, a membrana foi corada com Ponceau S (Sigma), para a visualização e marcação de bandas correspondente aos padrões de massa molecular. Após isso, a membrana foi lavada com PBS-T (0.05\% Tween 20 em PBS 1x) para remoção do Ponceau S e bloqueada com PBS-T acrescido de $10 \%$ de leite desnatado a $4{ }^{\circ} \mathrm{C}$ por 16 horas. Após esta etapa, a membrana foi lavada com PBS-T 0,05\% durante 10 minutos por 3 vezes em temperatura ambiente, e incubada com o antisoro de interesse diluído em PBS-T 0,05\% acrescido de $10 \%$ de leite desnatado por 90 minutos sob agitação, em temperatura ambiente. Em seguida, a membrana foi novamente submetida a 3 lavagens de 10 minutos com PBS-T 0,05\%. Após as lavagens, a membrana foi incubada com um anticorpo específico conjugado à peroxidase, diluído de acordo com o título previamente determinado por ELISA, em PBS-T 0,05\% com leite desnatado a $10 \%$ por uma hora sob agitação, em temperatura ambiente. Após isso, a membrana foi novamente lavada por 3 vezes com PBS-T 0,05\% e revelada com um substrato quimioluminescente (ECL - GE Healthcare), em temperatura ambiente, de acordo com as instruções do fabricante. Após a incubação com o substrato, a membrana foi exposta a filmes de raio- $X$. 


\subsection{Imunoprecipitação}

Para analisar o perfil de secreção de proteínas durante o crescimento de leptospira, o sobrenadante de cinco culturas de Leptospira interrogans sorovar Copenhageni, contendo 30 $\mathrm{mL}$ cada, foram coletados em dias diferentes.

Contando a partir do primeiro dia de cultivo, a cultura do $1^{\circ}, 3^{\circ}, 5^{\circ}, 7^{\circ}$ e $10^{\circ}$ dia foram centrifugadas $\left(12.800 \mathrm{x} \mathrm{g}, 4{ }^{\circ} \mathrm{C}, 30 \mathrm{~min}\right)$, e o sobrenadante foi coletado e armazenado a -20 ${ }^{\circ} \mathrm{C}$.

Para o ensaio de imunoprecipitação, as amostras de sobrenadante foram pré-limpas, com Proteína A-Sefarose, para remoção de imunoglobulinas IgG presente nos cultivos. Um volume de $1600 \mu \mathrm{L}$ do sobrenadante, de cada cultura, foi tratado com $50 \mu \mathrm{L}$ de Proteína $\mathrm{A}-$ Sefarose, previamente lavadas e incubadas por 2 horas, a $4{ }^{\circ} \mathrm{C}$, sob agitação. As amostras foram centrifugadas a $2000 \mathrm{rpm}$ por 1 minuto, para separação das Proteínas A-Sefarose e o sobrenadante foi coletado.

O sobrenadante agora "limpo" de IgG foi incubado com $8 \mu \mathrm{L}$ de antisoro, gerado contra a proteína de interesse, por 2 horas a $4{ }^{\circ} \mathrm{C}$, sob agitação. Após essa etapa, adicionou-se $50 \mu \mathrm{L}$ de Proteína A-Sefarose, previamente lavadas e, novamente, incubaram-se as amostras por 2 horas, a $4{ }^{\circ} \mathrm{C}$, sob agitação. Após o tratamento com Proteína A-Sefarose, as amostras foram centrifugadas a $2000 \mathrm{rpm}$, por 1 minuto e descartou-se o sobrenadante, ficando com o precipitado contendo a Proteína A-Sefarose ligada aos anticorpos e imunocomplexos.

O precipitado foi lavado 3 vezes com PBS, ressuspendido com $80 \mu \mathrm{L}$ de tampão SDSredutor $2 \mathrm{x}$ e fervido por $10 \mathrm{~min}$ antes de ser utilizado ou armazenado a $-20{ }^{\circ} \mathrm{C}$.

\subsection{Detecção de atividade proteolítica sobre substrato elastina}

O ensaio de proteólise sobre o substrato comercial Elastina-Congo Red (Sigma) foi realizado de acordo com o protocolo fornecido pelo fabricante (147). Resumidamente, o substrato insolúvel Elastina-Congo Red é incubado com a enzima de interesse em tampão 15 $\mathrm{mM}$ Tris $\mathrm{HCl}, \mathrm{pH} 8.0$, a $37{ }^{\circ} \mathrm{C}$ por 12 a 16 horas sob agitação. O substrato Elastina-Congo Red quando degradado se torna solúvel e o nível de degradação é determinado através de leituras de absorbância a $495 \mathrm{~nm}$. A inibição da atividade proteolítica foi avaliada através da 
adição de $15 \mathrm{mM}$ de EDTA. Como controle positivo foi utilizado elastase pancreática porcina comercial (Sigma).

\subsection{Zimografia em gel de poliacrilamida com SDS}

A zimografia é uma técnica na qual a matriz em que as proteínas serão separadas é composta por poliacrilamida co-polimerizada com determinados substratos, com a finalidade de se identificar atividades enzimáticas manifestadas por proteínas específicas. Este ensaio foi realizado para caracterizar uma possível atividade elastinolítica de uma das proteínas deste estudo. A metodologia empregada é a descrita por Heussen (148) com algumas modificações. Para este ensaio, foram utilizados géis na concentração de $12 \%$ de poliacdrilamida, contendo elastina solúvel bovina (Elastin Products Company, Missouri) na concentração final de $1 \mathrm{mg} / \mathrm{mL}$. A eletroforese ocorreu em temperatura de $4{ }^{\circ} \mathrm{C}$, voltagem de $100 \mathrm{~V}$, corrente de 40 mA e sobre condições não redutoras. Após a corrida, os géis foram lavados por 30 minutos em tampão Tris-HCl 50 mM pH 8,0, contendo 2,5\% do detergente Triton S-100 (Sigma), para remoção do SDS presente no gel. Em seguida, os géis foram lavados por 10 minutos em tampão Tris-HCl 50 mM, pH 8,0 para a remoção do Triton X-100. Por fim, o géis foram incubados em tampão Tris-HCl 200mM, pH 8,0 com $\mathrm{ZnCl}_{2} 5 \mathrm{mM}$ por 48 horas. Após esta etapa, os géis foram submetidos ao mesmo processo de revelação de bandas protéicas aplicado para SDS-PAGE, utilizando o corante Comassie Brilliant Blue, contudo, a descoloração foi feita até o aparecimento das áreas de atividade proteolítica.

\subsection{Desafio animal}

Os ensaios de imunização e desafio em hamsters foram feitos em colaboração com o laboratório de zoonoses bacterianas da Faculdade de Medicina Veterinária e Zootecnia da Universidade de São Paulo (FMVZ - USP), coordenado pelo professor Dr. Silvio Arruda Vasconcellos. As imunizações e sangrias dos animais foram realizadas em colaboração com a Dra. Patricia Antonia Estima Abreu de Aniz.

Grupos de dez hamsters machos jovens foram imunizados intraperitonealmente por 2 vezes, com $50 \mu \mathrm{g}$ da proteína recombinante juntamente com $500 \mu \mathrm{g}$ de adjuvante hidróxido de alumínio (proporção de $10 \mu \mathrm{g}$ de $\mathrm{Al}(\mathrm{OH})_{3}$ para cada $1 \mu \mathrm{g}$ de proteína recombinante, com 
um intervalo de 14 dias. No $28^{\circ}$ dia, os hamsters foram desafiados com cerca de $6 \times 10^{3}$ Leptospira interrogans sorovar Copenhageni injetadas intraperitonealmente. Após 21 dias do desafio, os animais sobreviventes foram sacrificados e seus rins foram triturados e examinados quanto à presença de leptospiras através de cultivo em meio EMJH. O controle positivo foi realizado com uma vacina comercial (Pfizer) e o controle negativo foi imunizado com PBS 1x ou não foi imunizado.

Os animais também tiveram o sangue coletado, pelo plexo retrorbital, antes de cada imunização e do desafio. O sangue coletado foi centrifugado, sob refrigeração, para obtenção do soro. 


\section{RESULTADOS}

\subsection{Identificação de genes}

Com o auxílio de ferramentas de bioinformática e a ferramenta de predição de sublocalização celular PSORTb v2.0.4, foram selecionados 12 genes (lic10881, lic20087, lic11211, lic10544, lic10291, lic13435, lic11399, lic10642, lic10359, lic12558, lic10995 e lic10468) que codificam proteínas hipotéticas conservadas, preditas como sendo de superfície externa ou secretada por $L$. interrogans sorovar Copenhageni, além do gene codificante para a região carboxi-terminal da proteína LigA e a região carboxi-terminal da proteína LytM de Staphylococcus aureus (tabela 3). O motivo pelos quais estas 2 últimas proteínas foram selecionadas é descrito adiante.

A atual versão da ferramenta de predição de sublocalização celular PSORTb v3.0.2, prediz que o gene lic10881 codifica para uma proteína de membrana interna e o gene lic10642 codifica para uma proteína citoplasmática, contrariando as predições realizadas inicialmente. $\mathrm{O}$ anexo A apresenta o alinhamento de cada proteína com as predições in silico dos domínios (quando presente), peptídeo sinal e sítios ligantes dos iniciadores (primers).

\subsection{Expressão e purificação de proteínas recombinantes}

Foi possível amplificar todos os genes selecionados por PCR, utilizando iniciadores específicos (primers) a partir do DNA genômico de L. interrogans sorovar Copenhageni. Os fragmentos amplificados foram clonados no vetor de expressão pAE e sua expressão foi avaliada em três linhagens de hospedeiro bacterianos de Escherichia coli. Somente a expressão das proteínas recombinantes LIC13435 (rLIC13435), LIC11399 (rLIC11399), e os fragmentos carboxi-terminal das proteínas recombinantes LIC11399 (ctLIC11399) e LigA (ctLigA) foram obtidas nos sistemas de expressão analisados. O fragmento carboxi-terminal de LytM (ctLytM) também foi amplificado por PCR, a partir do DNA genômico de Staphylococcus aureus, e expresso. Estas proteínas foram purificadas através de cromatografia de afinidade a metais bivalentes.

A proteína rLIC13435 foi expressa em bactéria a E. coli BL 21(SI), na fração solúvel e foi purificada do sobrenadante do lisado de bacteriano. O rendimento obtido foi de 
aproximadamente $20 \mathrm{mg}$ em 1 litro de meio de cultura e a concentração final foi de aproximadamente $1 \mu \mathrm{g} / \mu \mathrm{l}$ (figura 7).

Figura 7 - Gel de SDS-PAGE 15\% com curva padrão de BSA e concentrações crescentes da proteína recombinante rLIC13435. A análise por densitometria estimou a concentração da proteína em $1 \mu \mathrm{g}$ $/ \mu \mathrm{L}$. A proteína rLIC13435 possui massa molecular de aproximadamente 20,2 KDa. 1 - Indicador de massa molecular LMW; 2 - $8 \mu \mathrm{g}$ de BSA; $3-4 \mu \mathrm{g}$ de BSA; $4-2 \mu \mathrm{g}$ de BSA; 5 - $1 \mu \mathrm{g}$ de BSA; 6 - Vazio; 7- $5 \mu \mathrm{L}$ da amostra; $8-10 \mu \mathrm{L}$ da amostra; $9-15 \mu \mathrm{L}$ da amostra.

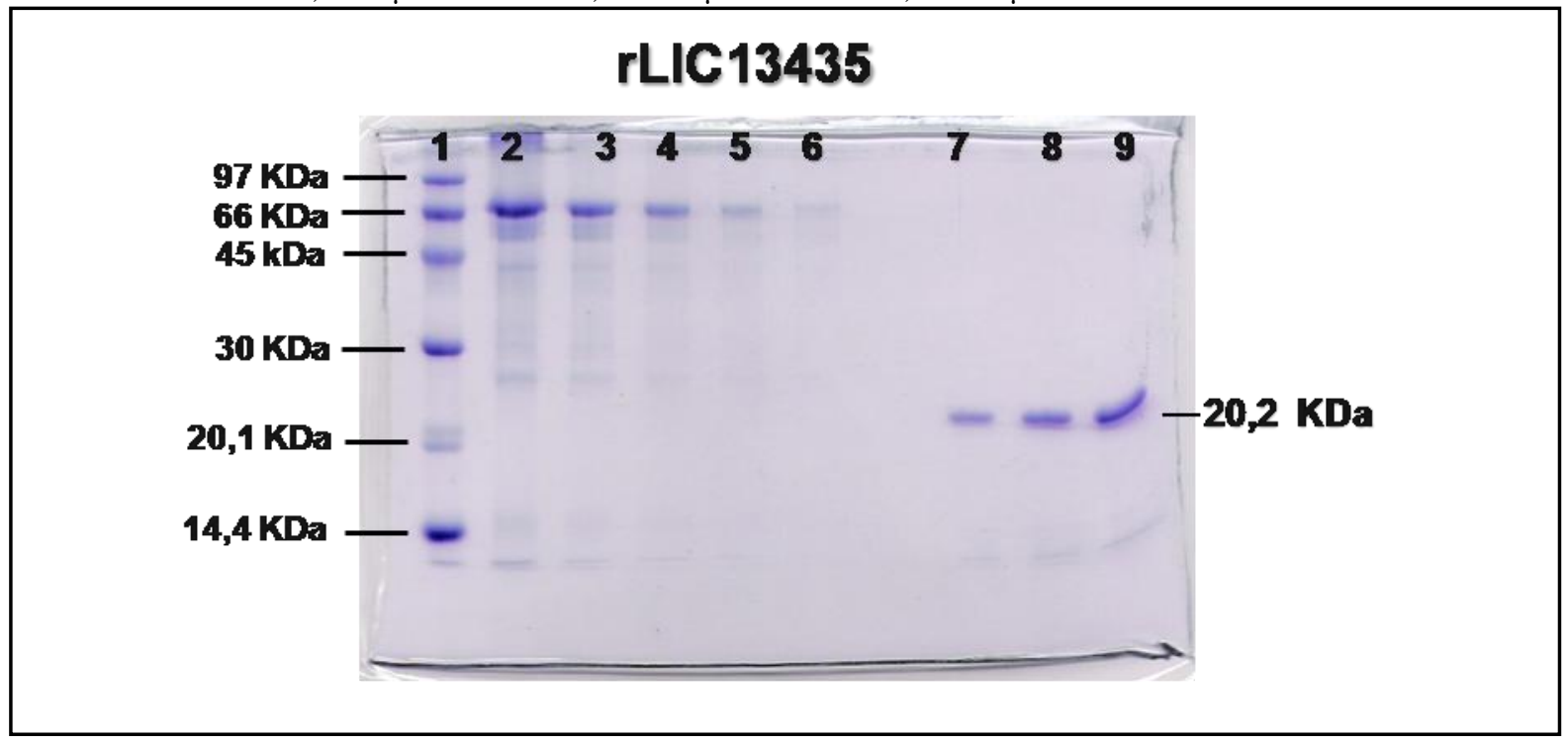

A proteína ctLigA foi amplificada, clonada e expressa na bactéria E. coli Star pLysS, induzível por IPTG. Sua expressão majoritária foi em forma de corpúsculo de inclusão e a purificação foi realizada após o processo de renaturação.

O rendimento final obtido foi de aproximadamente $20 \mathrm{mg}$ de proteína em um litro de cultura, em uma concentração de $0,1 \mu \mathrm{g} / \mu \mathrm{L}$ (figura 8). 
Figura 8 - Gel de SDS-Page 12\% com curva padrão de BSA e concentrações crescentes da proteína recombinante ctLigA. A análise por densitometria estimou a concentração da proteína em $0,1 \mu \mathrm{g} /$ $\mu \mathrm{L}$. A proteína ctLigA possui massa molecular de aproximadamente 44,2 KDa. 1 - Indicador de massa molecular LMW ; 2 - $8 \mu \mathrm{g}$ de BSA; 3 - $4 \mu \mathrm{g}$ de BSA; $4-2 \mu \mathrm{g}$ de BSA; 5 - $1 \mu \mathrm{g}$ de BSA; 6 $0,5 \mu \mathrm{g}$ de BSA; $7-5 \mu \mathrm{L}$ da amostra; $8-10 \mu \mathrm{L}$ da amostra; $9-15 \mu \mathrm{L}$ da amostra; $10-20 \mu \mathrm{L}$ da amostra.

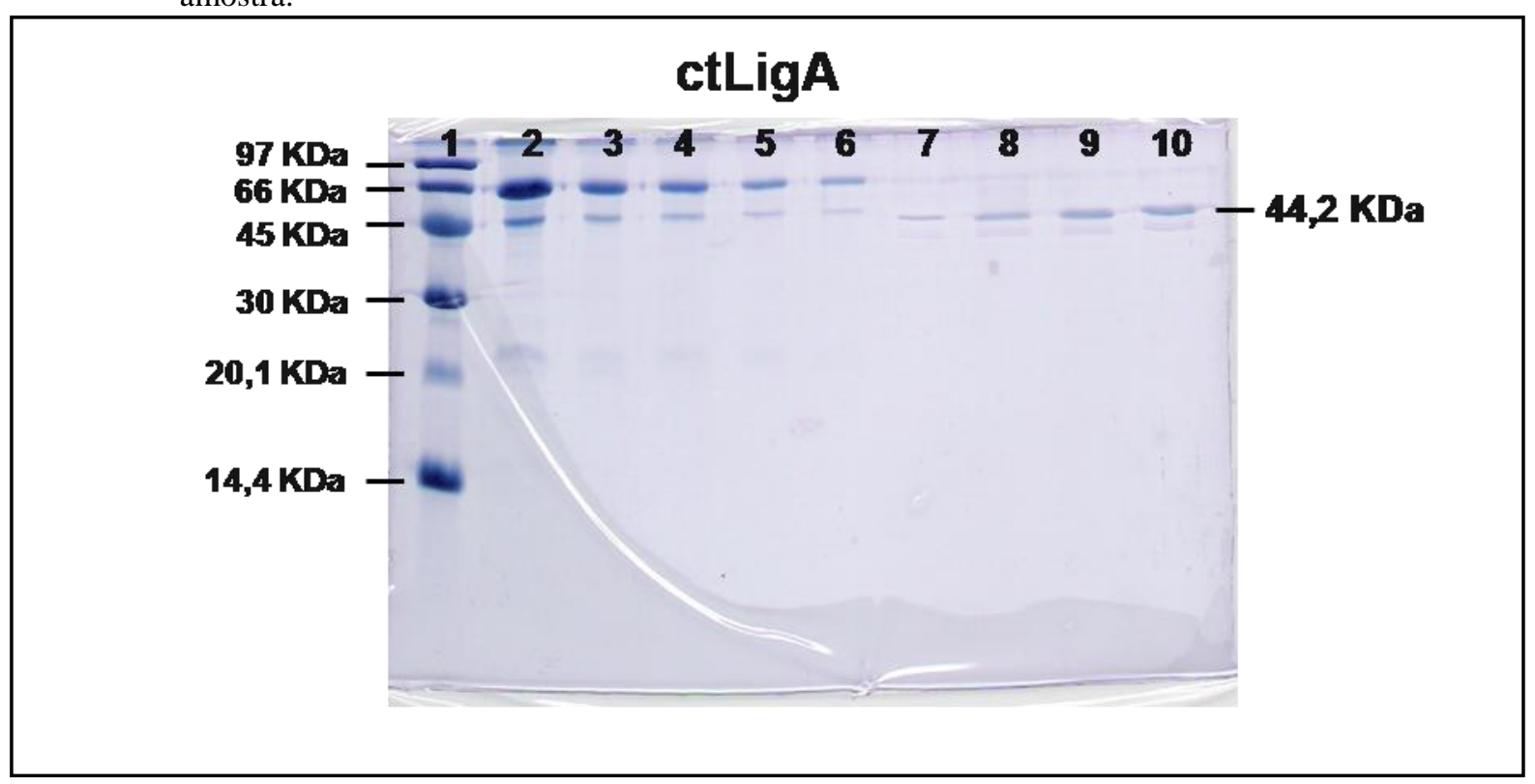

As proteínas rLIC11399 e ctLIC11399 foram expressas e purificadas. A bactéria utilizada para a expressão de ambas as proteínas foi a E. coli BL 21(SI). Em ambos os casos, a proteína foi majoritariamente expressa na fração insolúvel em forma de corpúsculo de inclusão. O processo de renaturação e a purificação foram realizados, conforme o protocolo descrito em materiais e métodos. O rendimento para 1 litro de meio de cultura foi de aproximadamente $20 \mathrm{mg}$ para ambas as proteínas, sendo que a concentração da proteína rLIC11399 foi de $0,1 \mu \mathrm{g} / \mu \mathrm{L}$, enquanto que para ctLIC11399 foi de aproximadamente $0,13 \mu \mathrm{g} / \mu \mathrm{L}$ (figuras 9 e 10 ). 
Figura 9 - Gel de SDS-Page 15\% com curva padrão de BSA e concentrações decrescentes da proteína recombinante rLIC11399. A análise por densitometria estimou a concentração da proteína em $0,08 \mu \mathrm{g} / \mu \mathrm{L}$. A proteína rLIC11399 possui massa molecular de aproximadamente $41 \mathrm{KDa}$. 1 Indicador de massa molecular LMW ; 2 - $8 \mu \mathrm{g}$ de BSA; 3 - 4 $\mu \mathrm{g}$ de BSA; 4 - $2 \mu \mathrm{g}$ de BSA; 5 - $1 \mu \mathrm{g}$ de

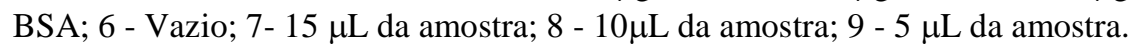

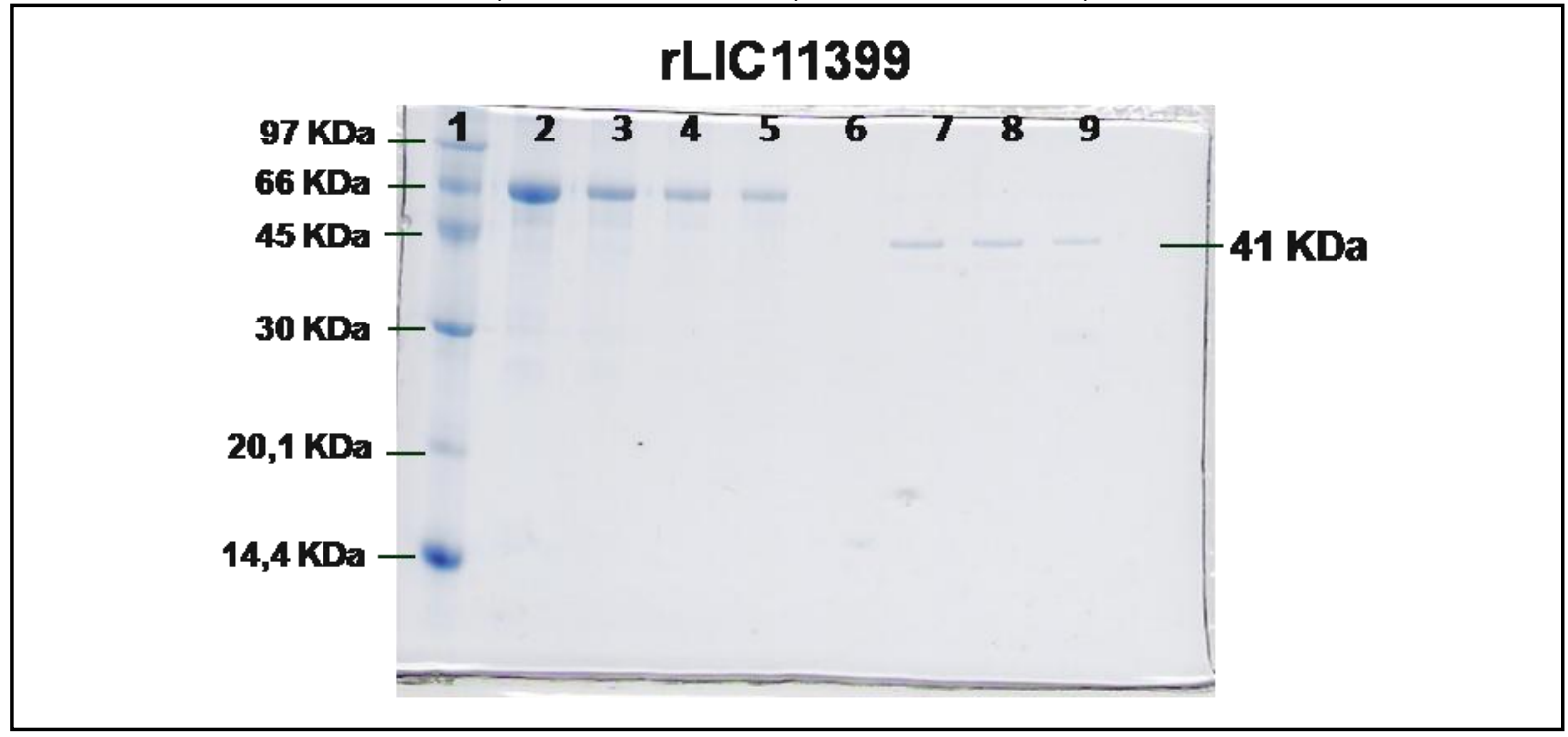

Figura 10 - Gel de SDS-Page 15\% com curva padrão de BSA e concentrações decrescentes da proteína recombinante ctLIC11399. A análise por densitometria estimou a concentração da proteína em $0,13 \mu \mathrm{g} / \mu \mathrm{L}$. A proteína ctLIC11399 possui massa molecular de aproximadamente 22,6 KDa. 1 Indicador de massa molecular LMW ; 2 - $8 \mu \mathrm{g}$ de BSA; 3 - 4 $\mu \mathrm{g}$ de BSA; 4 - $2 \mu \mathrm{g}$ de BSA; 5 - $1 \mu \mathrm{g}$ de BSA; $6-0,5 \mu \mathrm{L}$ de BSA ; 7- 20 $\mu \mathrm{L}$ da amostra; 8 - $15 \mu \mathrm{L}$ da $\operatorname{amostra} ; 9$ - $10 \mu \mathrm{L}$ da amostra; $10-$ $5 \mu \mathrm{L}$ da amostra.

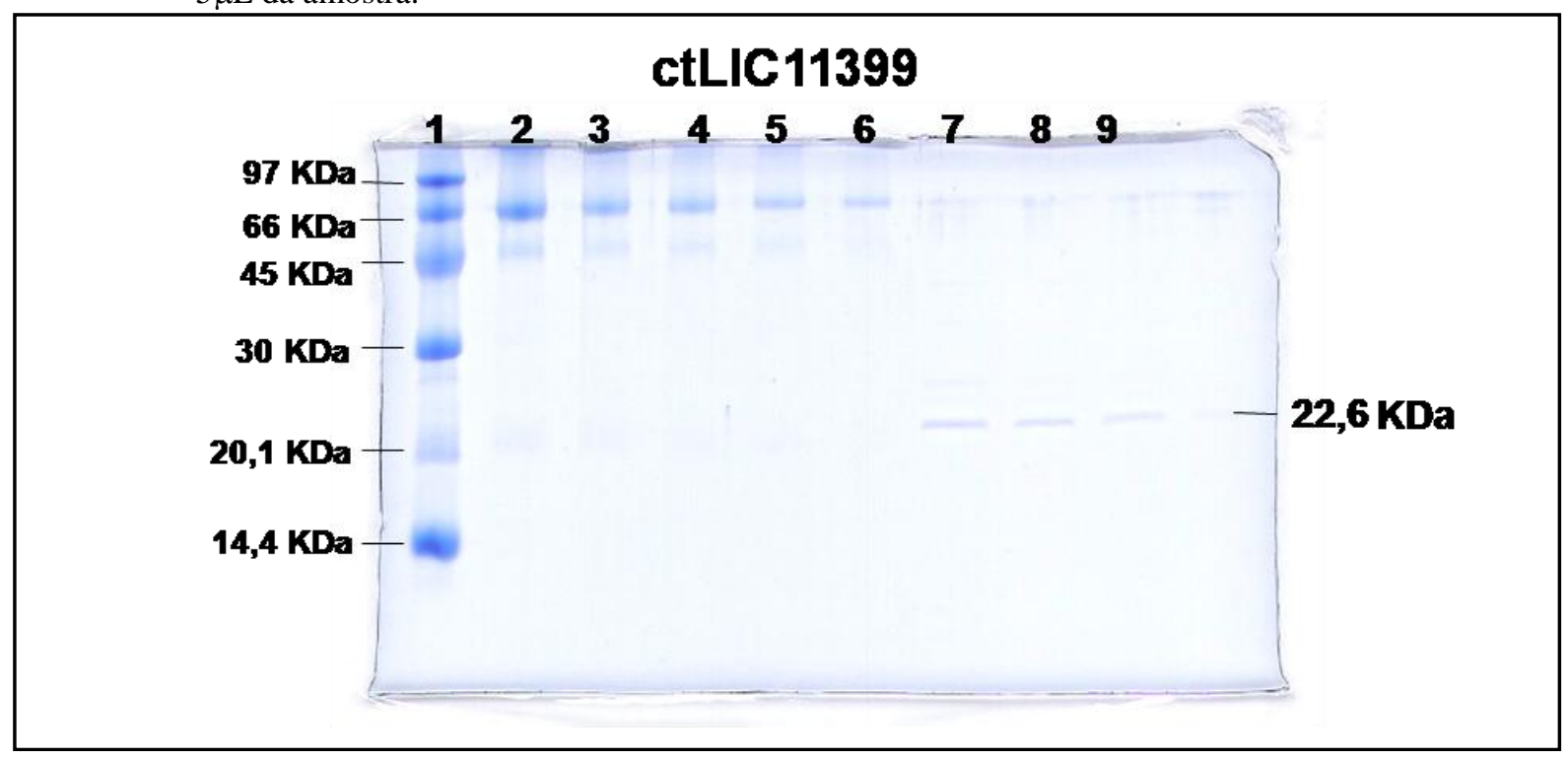

A proteína ctLytM foi expressa em bactéria E. coli BL21 (DE3) Star PlysS e foi purificada do sobrenadante do lisado de bactérias. O rendimento final da proteína foi de aproximadamente $35 \mathrm{mg}$ em 1 litro de meio de cultura em uma concentração de aproximadamente de 1,6 $\mu \mathrm{g} / \mu \mathrm{L}$ (figura 11). 
Figura 11 - Gel de SDS-Page 15\% com curva padrão de BSA e concentrações crescentes da proteína recombinante ctLytM. A análise por densitometria estimou a concentração da proteína em 1,6 $\mu \mathrm{g} / \mu \mathrm{L}$. A proteína ctLytM possui massa molecular de aproximadamente 16,2 KDa. 1 - Indicador de massa molecular LMW ; 2 - $5 \mu \mathrm{L}$ da amostra; $3-10 \mu \mathrm{L}$ da amostra; $4-15 \mu \mathrm{L}$ da amostra; $5-0,5 \mu \mathrm{g}$ de BSA; 6 - $1 \mu \mathrm{g}$ de BSA; $7-2 \mu \mathrm{g}$ de BSA; $8-4 \mu \mathrm{g}$ de BSA $; 9-8 \mu \mathrm{g}$ de BSA.

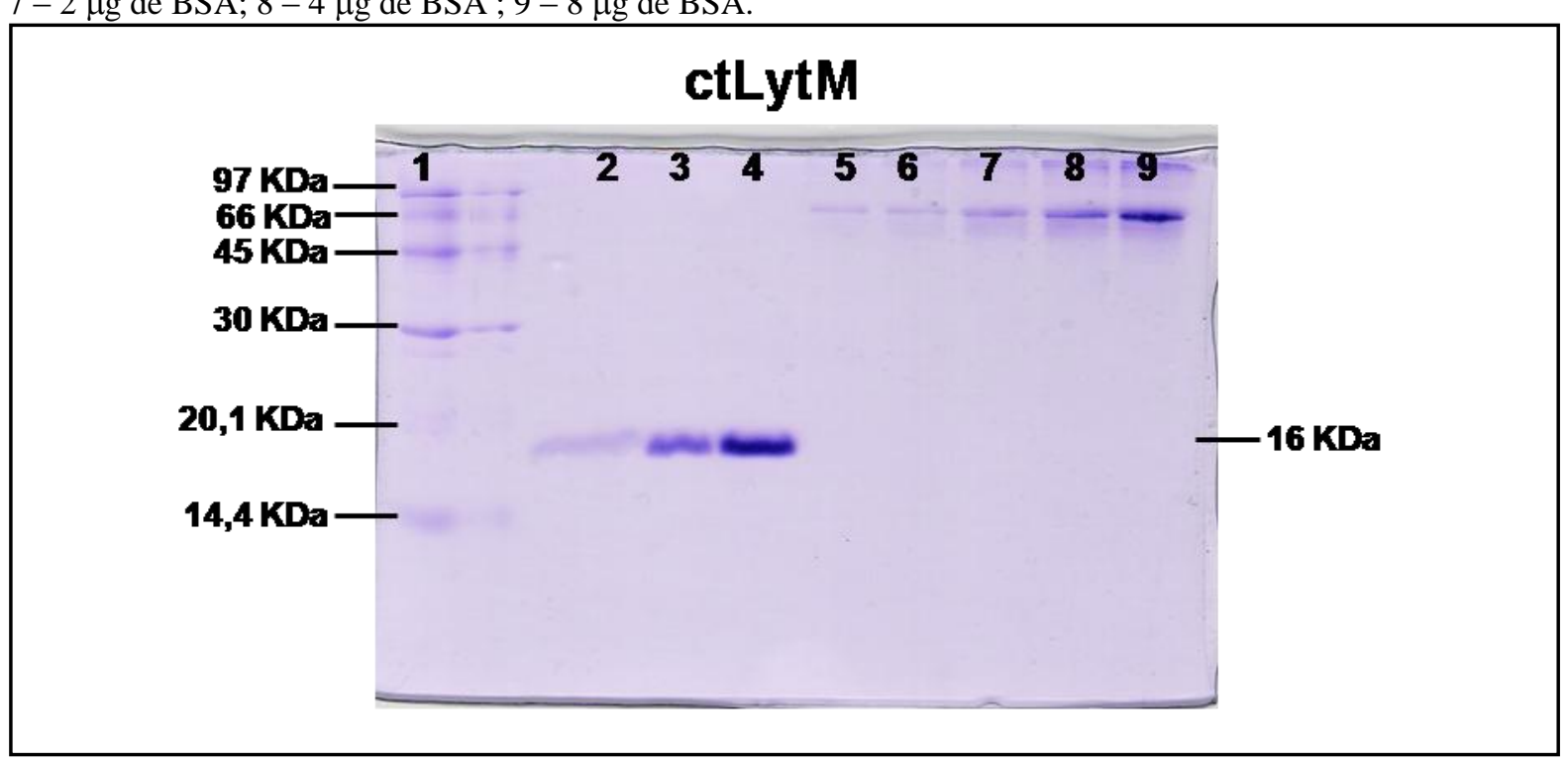

\subsection{Análise bioinformática complementar do gene lic13435}

As análises in silico do gene lic13435 revelaram que esta proteína não possui domínios definidos e que genes ortólogos da proteína LIC13435 estão presentes nos genomas de leptospiras patogênicas, porém ausente no genoma de leptospiras de vida livre (não patogênicos) seqüenciados até agora (figura 12). 
Figura 12 - Alinhamento do gene lic13435 com genes homólogos de diferentes genomas de Leptospira. Seqüência do gene lic13435 de L. interrogans sorovar Copenhageni cepa. Fiocruz L1-130 (GenBank Accession No. AE016823.1) alinhado com genes homólogos dos genomas de $L$. interrogans sorovar Lai cepa 56601 (GenBank Accession No. AE010300.1), L. borgpetersenii sorovar Hardjo-bovis JB197 (GenBank Accession No. CP000350.1) e L. borgpetersenii sorovar Hardjo-bovis L550 (GenBank Acceession No. CP000348.1). O asterisco indica aminoácidos idênticos, dois pontos indicam aminoácidos com propriedades químicas semelhantes e, um ponto indica aminoácidos com propriedades químicas diferentes.

\begin{tabular}{|c|c|c|}
\hline L.i.Copenhageni & \multicolumn{2}{|l|}{ MIYSKISFYGIITVFLFGIFSVIQAQTLDQNQYQKIKAVVTQTGHIEKETLVREVYAINS 60} \\
\hline L.i.Lai & \multicolumn{2}{|l|}{ MIYSKISFYGIITVFLFGIFSVIQAQTLDQNQYQKIKAVVTQTGHIEKETLVREVYAINS 60} \\
\hline L.b.Hardjo_JB197 & \multicolumn{2}{|l|}{ MMKVKISFHSIIVAFLFGIPFGIQAQVLDQSQYQKIKAVVTQTGHIEKETLMREIYAINP 60} \\
\hline L.b_Hardjo_L550 & \multicolumn{2}{|l|}{ MMKVKISFHSIIVAFLFGIPFGIQAQVLDQSQYQKIKAVVTQTGHIEKETLMREIYAINP 60} \\
\hline & \multicolumn{2}{|l|}{ 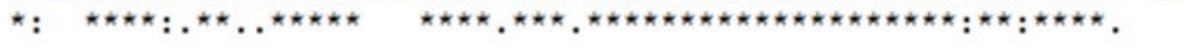 } \\
\hline L.i.Copenhageni & \multicolumn{2}{|l|}{ NPQEYLIALTKDPDLRVYALSQINELIADFGGNSAINYLESTIANENAHPSIRSSAAFSY 120} \\
\hline L.i.Lai & NPQEYLIALTKDPDLRVYALSQINELIADFGGNSAINYLESTIANENAHPSIRSSAAFSY 12 & 120 \\
\hline L.b.Hardjo_JB197 & NPQEYLVAIAKDPELRVYAISQLNELIADFGANSARDYLESTISNESTHPSIRNSAVFSY & 120 \\
\hline L.b_Hardjo_L550 & \multirow{2}{*}{\multicolumn{2}{|c|}{ 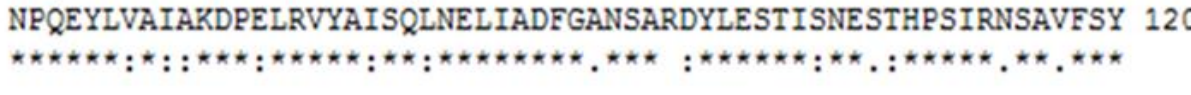 }} \\
\hline & & \\
\hline L.i.Copenhageni & \multicolumn{2}{|l|}{ GKTFYFSDRIRTENELNRYSANDQIGVSIRNTLRGLRTGKINSIRESERLKKENLNRIQN 180} \\
\hline L.i.Lai & GKTFYFSDRIRTENFLNRYSANDQIGVSIRNTLRGLRTGKINSIRFSERLKKENLNRIQN 18 & 180 \\
\hline L.b.Hardjo_JB197 & \multicolumn{2}{|l|}{ GKTFYFSDRNHAENFLKRFSSHDRIGTFVQNTLKELRMGKISSIRESEKLKKENMDRIKN 18} \\
\hline L.b_Hardjo_L550 & \multirow{3}{*}{\multicolumn{2}{|c|}{ 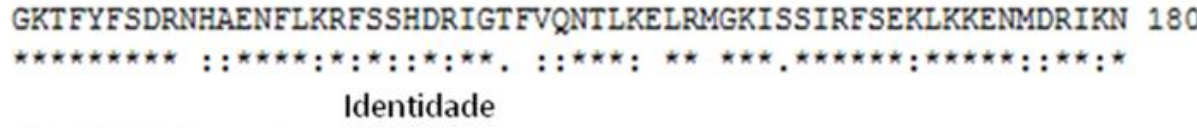 }} \\
\hline & & \\
\hline & & \\
\hline L.i.Copenhageni & \multicolumn{2}{|l|}{ KNLKKTDPSN--- $190 \quad 100 \%$} \\
\hline L.i.Lai & \multicolumn{2}{|l|}{ KNLKKTDPSN--- $190 \quad 100 \%$} \\
\hline L.b.Hardjo_JB197 & \multicolumn{2}{|l|}{ GNLRMPDPSIKNP $193 \quad 71 \%$} \\
\hline L.b_Hardjo_L550 & \multicolumn{2}{|l|}{ GNLRMPDPSIKNP $193 \quad 71 \%$} \\
\hline & \multicolumn{2}{|l|}{$\star \star *: .^{\star \star \star}$} \\
\hline
\end{tabular}

\subsection{Análise bioinformática complementar do gene lic11399}

As análises in silico do gene lic11399 indicam que genes ortólogos estão presentes nos genomas de leptospira patogênicas seqüenciados até agora e ausente no genoma de leptospira não patogênica (figura 13). Além disso, as análises também indicam que o gene possui dois domínios distintos: Um domínio semelhante aos fatores V e VIII da cascata de coagulação na porção amino-terminal (resíduos 56 aa a 173 aa) e um domínio semelhante ao de metalopeptidase da família M23 na porção carboxi-terminal (resíduos 218 aa a 363 aa). A família M23 compreende metaloproteases dependentes de zinco, secretadas, com atividade elastinolítica e está presente em diversos microorganismos (135, 149, 150). Assim sendo, baseado nos trabalhos relacionados às metaloproteases já descritos até então, optamos por clonar, expressar e purificar a porção carboxi-terminal da proteína LytM (ctLytM) de Staphylococcus aureus para utilizarmos como um controle em nossos experimentos. LytM é 
uma metaloprotease bastante caracterizada com o domínio catalítico similar ao da LIC11399 (135, 151, 152). A figura 14 mostra a identidade entre a seqüência de aminoácidos de LIC11399 com a seqüência de LytM de Staphylococcus aureus e os prováveis sítios ligantes a zinco em LytM (HXXXD e HXH). Com auxílio do programa de modelagem PyMOL, foi possível gerar a provável estrutura terciária tridimensional da proteína rLIC11399. A figura 15 mostra a modelagem tridimensional obtida para rLIC11399 em comparação com a estrutura cristalográfica caracterizada para a proteína LytM (135). A estrutura terciária do provável domínio catalítico da metaloprotease de rLIC11399 é similar ao da proteína LytM de Staphylococcus aureus. Odintsov et. al. demonstraram que a proteína recombinante LytM tem como principal substrato a elastina e sua atividade enzimática é aumentada quando clivada, sugerindo que a proteína seja uma pré-enzima com atividade elastinolítica. Por este motivo, optamos por clonar, expressar e purificar a região carboxi-terminal de LIC11399 (ctLIC11399) e de LytM (ctLytM) exatamente da mesma maneira à descrita no artigo, para utilizarmos em teste de atividade proteolítica com as proteínas rLIC11399 e ctLIC11399 sobre o substrato Elastin Congo-Red (Sigma). 
Figura 13 - Alinhamento do gene lic11399 com genes ortólogos de diferentes genomas de Leptospira. Seqüência do gene lic11399 de L. interrogans sorovar Copenhageni cepa Fiocruz L1-130 (GenBank Accession No. AE016823.1) alinhado com genes homólogos dos genomas de $L$. interrogans sorovar Lai cepa 56601 (GenBank Accession No. AE010300.1), L. borgpetersenii sorovar Hardjo-bovis JB197 (GenBank Accession No. CP000350.1) e L. borgpetersenii sorovar Hardjo-bovis L550 (GenBank Acceession No. CP000348.1). O asterisco indica aminoácidos idênticos, dois pontos indicam aminoácidos com propriedades químicas semelhantes e, um ponto indica aminoácidos com propriedades químicas diferentes.

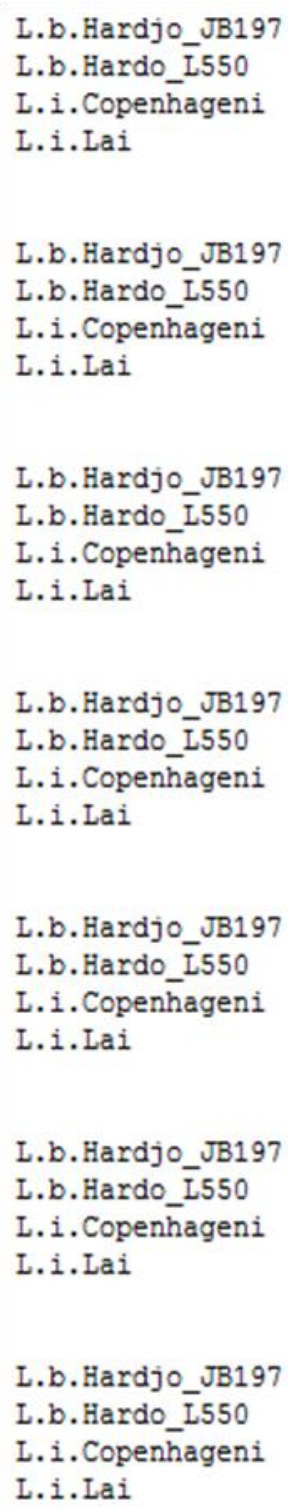

YEVQVLIRDDWRTIFVNQDVALHNFHKLENLDASVLRIYFPDTTDRGVVISDLKLFLNQQ 177 YEVQVLIRDDWRIIFVIQDVALHNFHKLENLDASVLRIYFPDTTDRGVISDLKLFLNQQ 177 YEIQVLIRDDWRI ILTNQNVELHNFHKLGNIDASVLRIYFPDSTNREVVISDLKLFLNQK 180 YEIQVLIRDDWRTILTNQNVELHNFHKLGNIDASVLRIYFPDSTNREVVISDLKLFLNQK 180

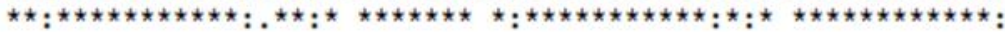

LLNGIEPRLRGYTFPVPDGLIPSLDFQLPNAPRVYRNGVHKGIDIYKKKEPSGQIRNLNF 237 LLNGIEPRLRGYTFPVPDGLIPSLDFQLPNAPRVYRNGVHKGIDIYKKKEPSGQIRNLNF 237 LLNGIEPRLRGYSFPVPDGLISSFDSQLPNAPRTYRNGVHKGIDIYKKKELDGQIRNLNF 240 LLNGIEPRLRGYSFPVPDGLISSFDSQLPNAPRTYRNGVHKGIDIYKKKELDGQIRNLNF 240

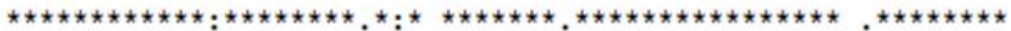

QDEAVSPADGVIVRADHSYFPMTSADYEYHTSQSQKGTVTYVEKDFGGRQVWIDHGHGVM 297 QDEAVSPADGVIVRADHSYFPMTSADYEYHTSQSQKGTVTYVEKDFGGRQVWIDHGHGVM 297 QDEIISPADGIVIRADHSYSPMTLSDYEYHTTQSQKGTVTYVEKDFGGRQVWIDHGHGVM 300 QDEIISPADGIVIRADHSYSPMTLSDYEYHTTQSQKGTVTYVEKDFGGRQVWIDHGHGVM 300

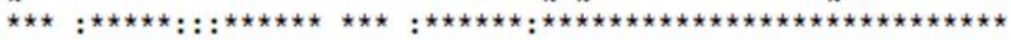

SSFNHLSSIRKNLKIGNKVKRGEVIGTIGNSGLMEEAKGITDNAHLHFEIWVDGEFFGNG 357 SSFNHLSSIRKNLKIGNKVKRGEVIGTIGNSGLMEEAKGITDNAHLHFEIWVDGEFFGNG 357 TSFNHLSSIHKNIKVGEKVKQGESIGTVGNSGLLEEAKNISDNIHLHFEIWVDGEFLGNG 360 TSFNHLSSIHKNIKVGEKVKQGESIGTVGNSGLLEEAKNISDNIHLHFEIWVDGEFLGNG 360

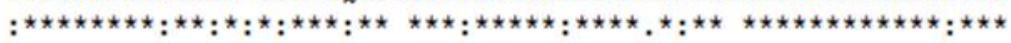

\section{Identidade}

VAPVQVRKMLQFFFKRNGAD $377 \quad \mathbf{8 0 \%}$ VAPVQVRKMLQFFFKRNGAD $377 \quad \mathbf{8 0 \%}$ LPPAQVRKLLQFFFKRNGVD $380 \quad \mathbf{1 0 0} \%$ LPPAQVRKLLQFFFKRNGVD $380 \quad \mathbf{9 9 \%}$

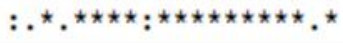


Figura 14 - Homologia entre a sequiência de aminoácidos de LIC11399 com a seqüência de LytM de Staphylococcus aureus. As setas indicam homologia entre os prováveis sítios ligantes a zinco em LytM (HXXXD e HXH).

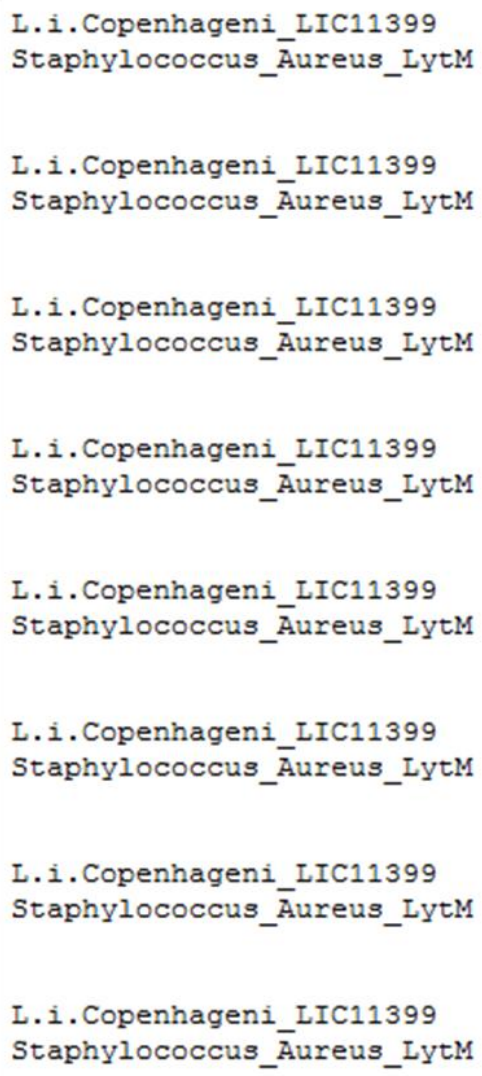

Figura 15 - Imagem tridimensional da estrutura terciária das proteínas rLIC11399 e LytM. A: Provável estrutura terciária da proteína rLIC1139. A esfera representa uma molécula de zinco que se liga aos respectivos sítios ligantes (em branco). B: Estrutura tridimensional da proteína LytM de Staphylococcus aureus. A esfera representa uma molécula de zinco, cofator do domínio metaloprotease.
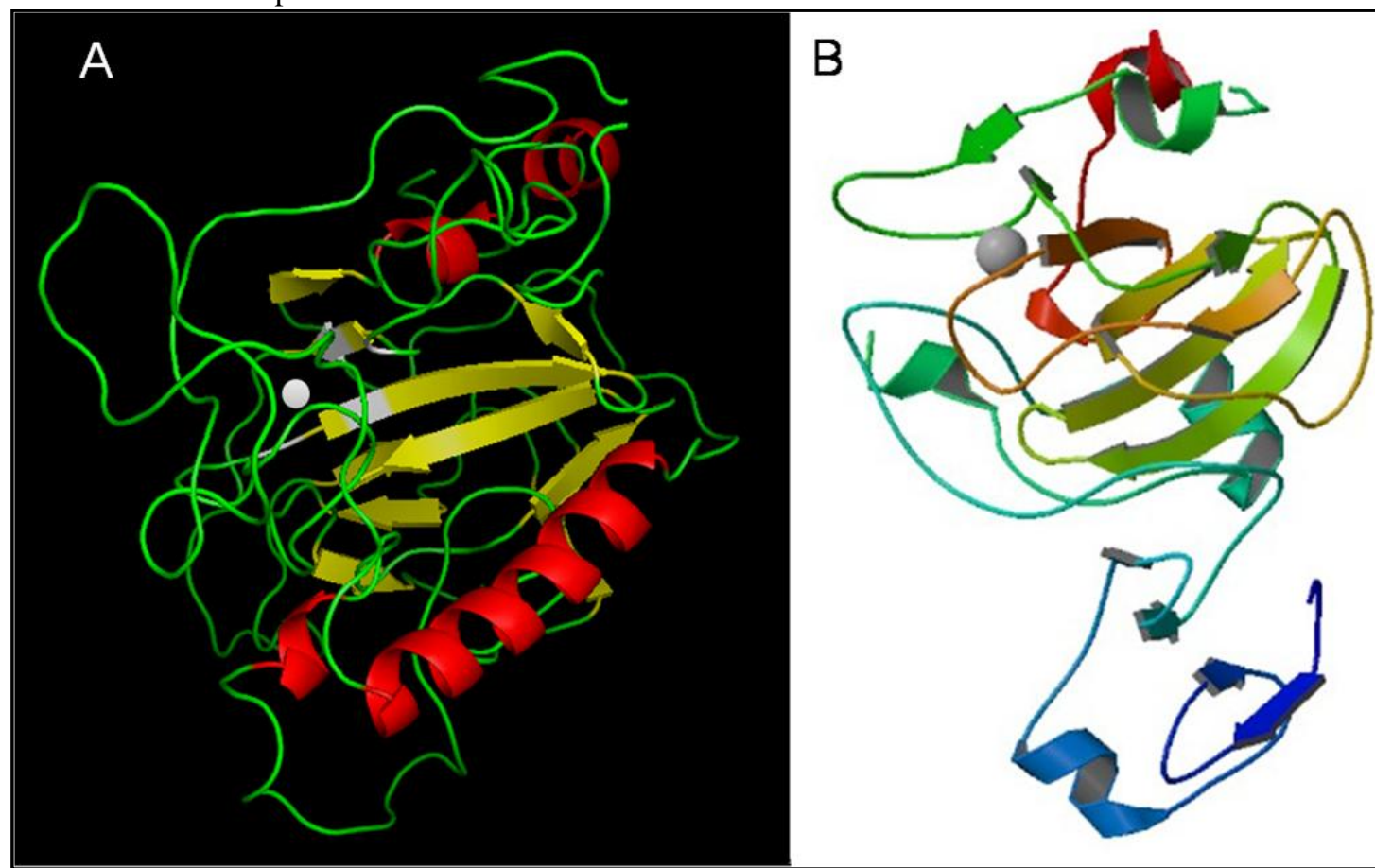


\subsection{Seqüenciamento da porção amino-terminal da proteína rLIC13435}

Com o propósito de confirmar se a proteína purificada realmente é a rLIC13435, foi realizado o seqüenciamento dos primeiros 15 resíduos de aminoácidos da porção amino terminal, pelo método de Edman. O resultado do seqüenciamento obtido confirmou que a proteína purificada é a rLIC13435. A seqüência obtida foi: M-H-H-H-H-H-H-L-E-G-S-Q-TL-D, sendo que os primeiros 11 resíduos são do vetor de expressão pAE e os 4 resíduos restantes são da proteína rLIC13435.

\subsection{Avaliação da conservação do gene lic13435 em genomas de leptospiras patogênicas}

Utilizando o mesmo par de primers desenhado para o gene lic13435 de Leptospira interrogans sorovar Copenhageni, foi feito um PCR a partir do DNA genômico de 9 sorovares de leptospira patogênicas sendo 8 da espécie L. interrogans (sorovares Pomona, Canicola, Copenhageni, Icterohaemorrhagie, Hardjo, Pyrogenes, Autumnalis, Bratislava), 1 da espécie L. kirschneri sorovar Grippotyphosa e 1 espécie de Leptospira saprófita (L. biflexa sorovar Patoc). Foi possível detectar a amplificação de genes ortólogos somente nos DNA genômicos de leptospiras patogênicas, indicando que este gene é conservado entre os sorovares patogênicos testados e, como esperado, não foi detectado amplificação no DNA genômico de Leptospira biflexa Patoc (figura 16).

Figura 16 - Amplificação do gene lic13435 a partir de DNAs genomicos de Leptospira. O DNA genômico de cultivos de Leptospira variados foi extraído e amplificado por PCR utilizando primers específicos para LIC13435. 1 - Marcador de massa molecular de $1 \mathrm{~Kb}$; 2 - L. interrogans sorovar Copenhageni; 3 - L. interrogans sorovar Icterohaemorrhagie; 4 - L. interrogans sorovar Pomona; 5 - L. kirschneri sorovar Grippotyphosa; 6 - L. interrogans sorovar Hardjo; 7 - L. interrogans sorovar Canicola; 8 - L. interrogans sorovar Bratislava; 9 - L. interrogans sorovar Autumnalis; 10 - L. interrogans sorovar Pyrogenes; 11 - L. biflexa sorovar Patoc.

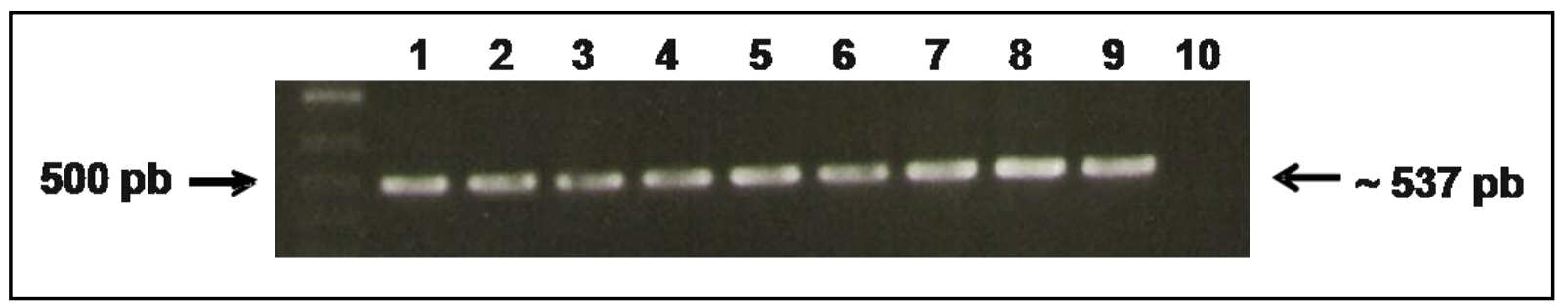




\subsection{Avaliação da presença de transcritos gênicos do gene lic13435}

O RNA total de algumas espécies de leptospira foi extraído e transcrito em DNA complementar (cDNA) para análise por RT-PCR.

As análises por RT-PCR utilizando cDNA de 2 leptospiras patogênicas ( $L$. interrogans sorovar Pomona e Canicola) e de 1 leptospira não patogênica (L. biflexa sorovar Patoc), revelaram que além do gene estar presente nos genomas de bactérias patogênicas, o mesmo está sendo transcrito. O DNA genômico de L. interrogans sorovar Copenhageni foi utilizado como controle positivo (figura 17).

Transcritos gênicos de 2 leptospiras patogênicas (L. interrogans sorovares Pomona e Canicola) em variados estágios de virulência (amostras LPF e LO4 respectivamente), e suas respectivas bactérias atenuadas (de muitas passagens, POM A e CAN A respectivamente) também foram avaliadas. Os resultados indicam a presença de transcritos gênicos de LIC13435 (figura 18).

Figura 17 - Amplificação de transcritos gênicos lic13435 de Leptospira. O RNA de cultivos de Leptospira variados foi extraído e retro-transcrito. O cDNA obtido foi utilizado em um PCR utilizando primers específicos para LIC13435. O DNA genômico de L. interrogans sorovar Copenhageni foi utilizado como controle positivo. 1 - Marcador de massa molecular; 2 - cDNA de L. interrogans sorovar Pomona; 3 - cDNA de L. biflexa sorovar Patoc; 4 - cDNA de L. interrogans sorovar Canicola; 5gDNA de L. interrogans sorovar Copenhageni.

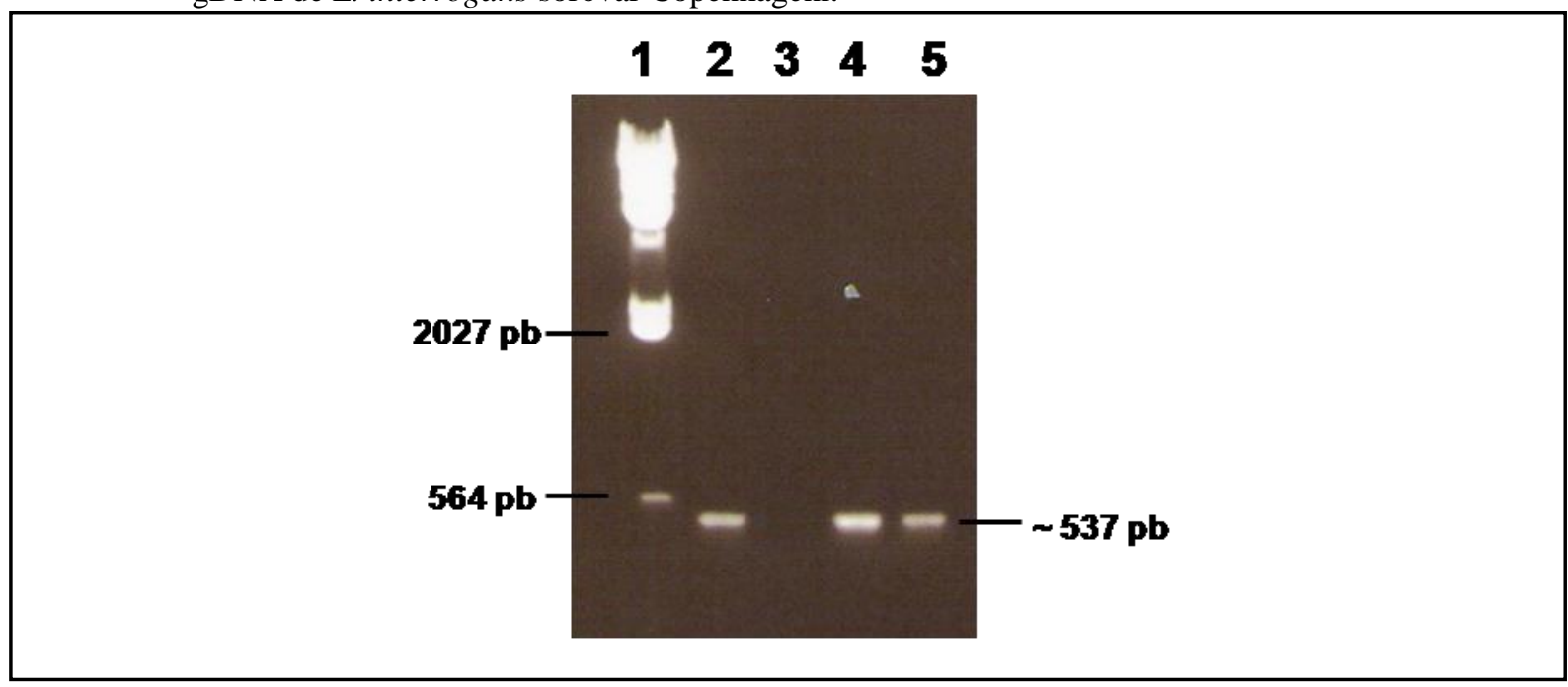


Figura 18 - Amplificação de transcritos gênicos de Leptospira. O RNA de cultivos de Leptospira variados foi extraído e retro-transcrito. O cDNA obtido foi utilizado em um PCR utilizando primers específicos para LIC13435 (RT+). Um controle negativo (RT-), sem retro-transcrição, foi realizado para cada amplificação para excluir a possibilidade de contaminação com DNA genômico. As siglas LPF e POM A correspondem a L. interrogans sorovar Pomona virulento e atenuado respectivamente. As siglas LO4 e CAN A correspondem a L. interrogans sorovar Canícola virulento e atenuado respectivamente. O número após as siglas LPF e LO4 correspondem ao número de passagem da cultura.

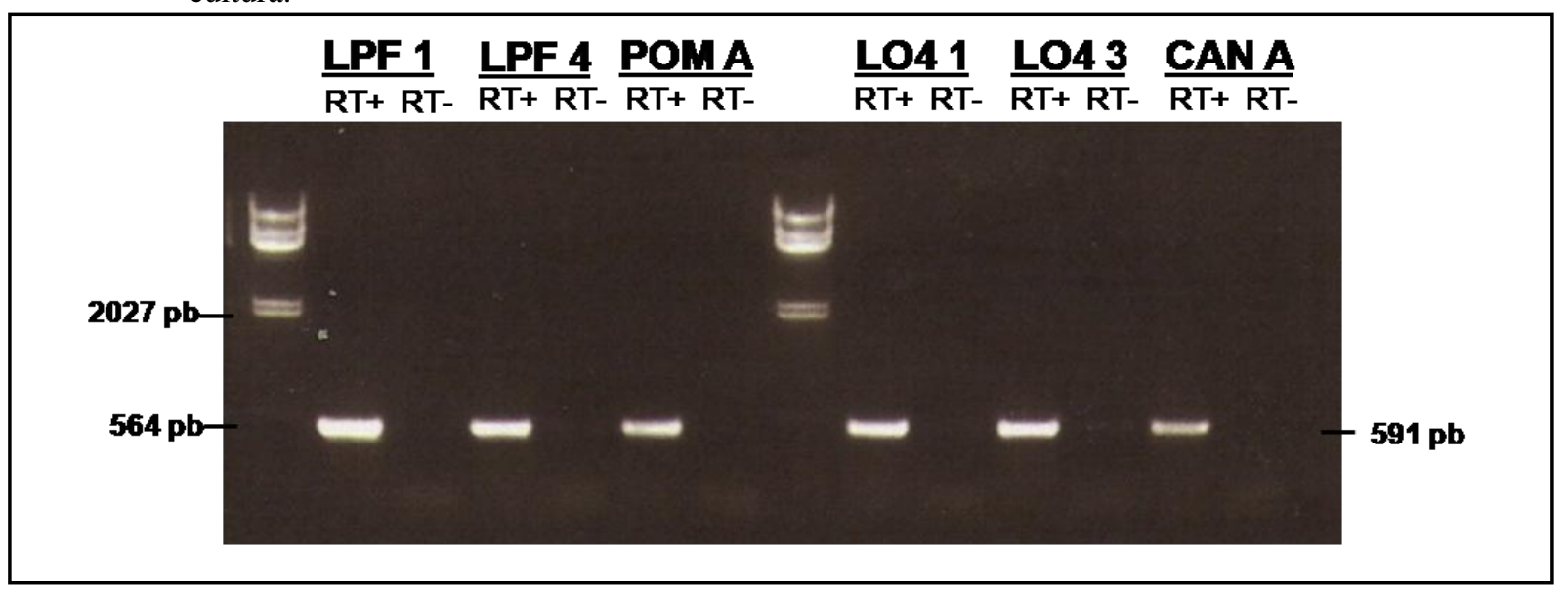

\subsection{Análise da estrutura secundária por dicroísmo circular (CD)}

Dicroísmo circular (CD) é uma técnica reconhecida para avaliação da estrutura secundária de proteínas em solução. Os diferentes tipos de estruturas secundárias regulares encontradas em proteínas em solução dão origem a espectros de CD característicos conforme demonstrado na figura $19(142,153)$. Foram tomados 3 espectros de cada proteína recombinante e as médias resultantes estão representadas na figura 20. Os dados gerados pelo CD foram interpretados com o auxílio do algoritmo CONTIN (http://s-provencher.com/pages/contin-cd.shtml) (143).

Os espectros obtidos indicam que todas as proteínas apresentam estrutura secundária regular e possuem integridade estrutural. Os resultados gerados por CD foram comparados com a predição de estrutura secundária teórica, obtida com o auxílio do programa público GOR (GOR IV Secondary Structure Prediction Method http://npsa-pbil.ibcp.fr/cgibin/npsa_automat.pl?page=npsa_gor4.html) (144), a partir da sequência de aminoácidos de cada proteína conforme a figura 21. 
Figura 19 - Espectro de CD associado a vários tipos de estrutura secundária. Linha sólida, alfa-hélice; tracejado longo, folha-beta antiparalela; linha pontilhada,volta - beta tipo 1; tracejado cruzado, hélice $3_{1}$ estendida ou hélice poli II (pro); tracejado curto, estrutura irregular.

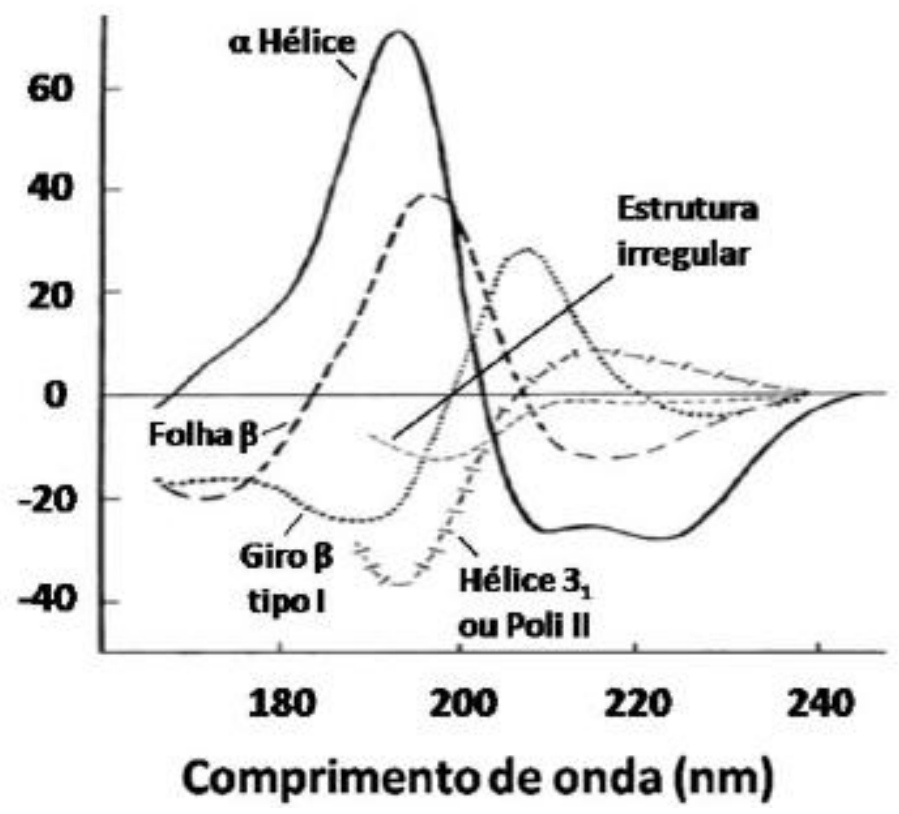

Fonte: Adaptado de Kelly et al., 2005 (142). 
Figura 20 - Espectro de CD obtido para cada proteína recombinante. Os espectros obtidos evidenciam que as proteínas recombinantes possuem estrutura secundária regular. Um exemplo dos padrões de espectro associados a vários tipos de estruturas secundárias ordenadas é mostrado.

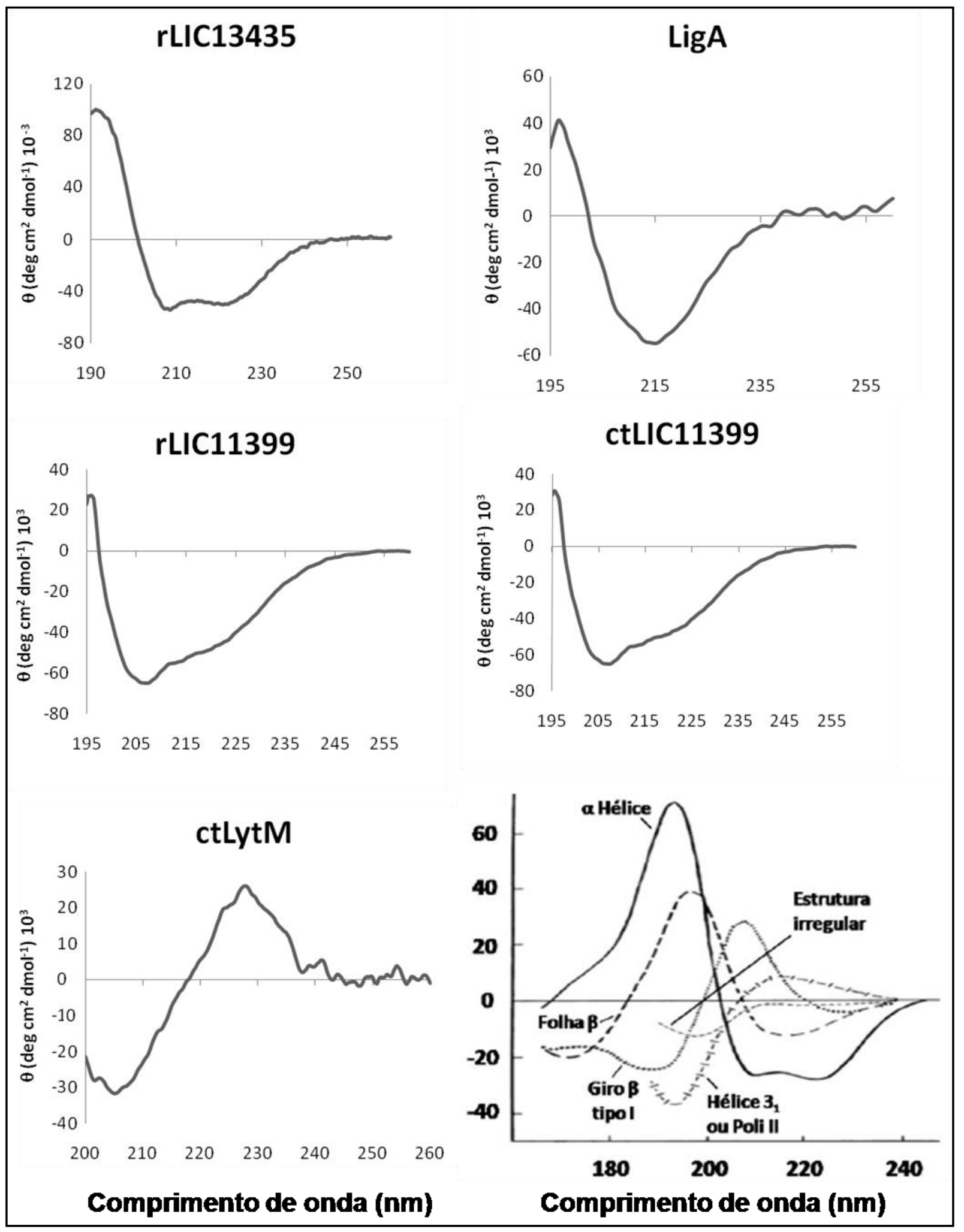


Figura 21 - Avaliação da estrutura secundária obtida por CD. Os dados gerados por CD foram comparados com a estrutura secundária predita para cada proteína.

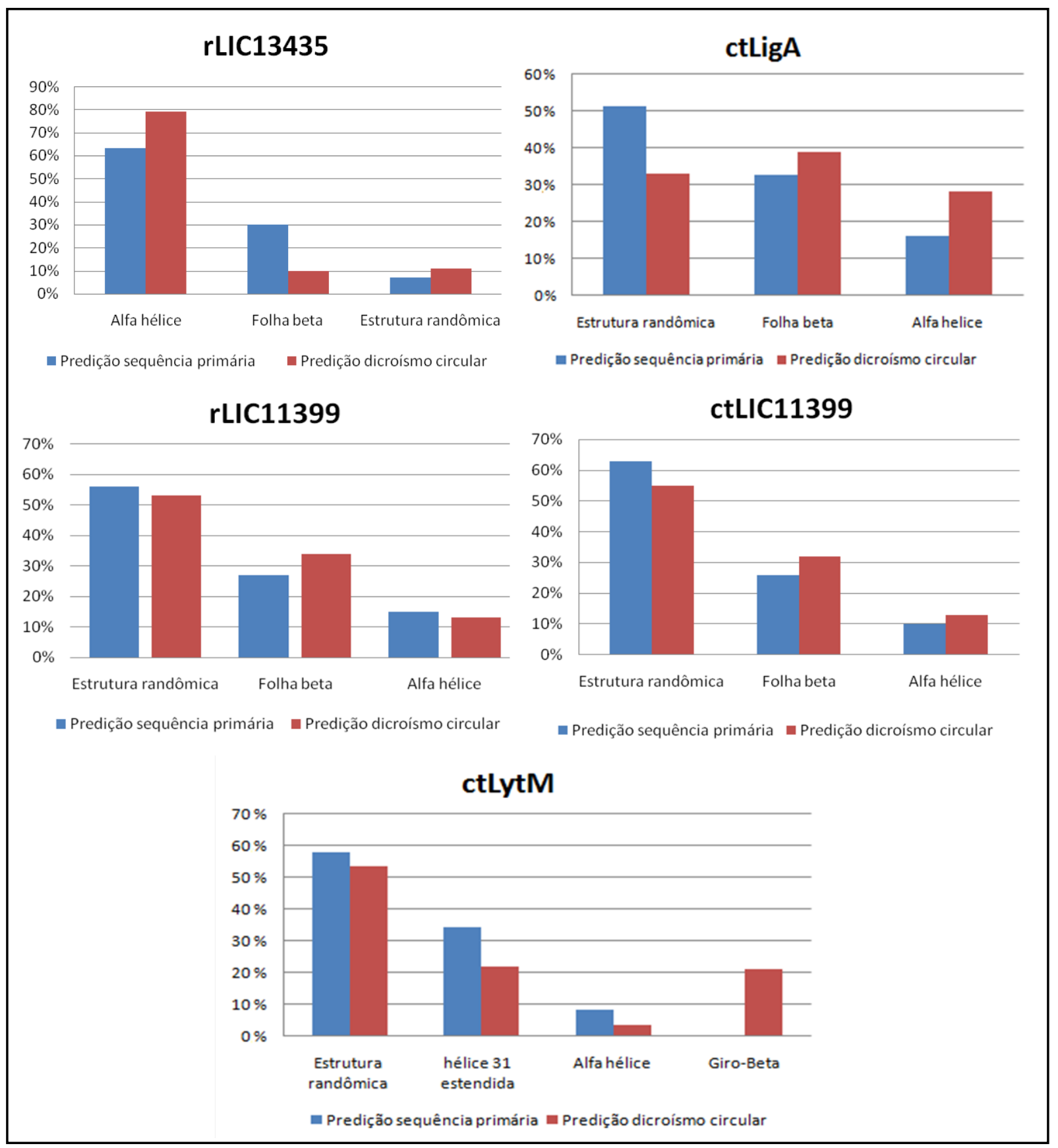

\subsection{Avaliação da imunogenicidade das proteínas geradas em camundongos}

O soro coletado após cada imunização foi avaliado quanto à imunogenicidade das proteínas testadas. Todos os soros coletados tiveram seus anticorpos titulados por ELISA. Os títulos obtidos foram de 512.000 para os soros anti-rLIC13435, anti-rLIC11399 e antictLIC11399. Para o soro anti-ctLigA o título obtido foi de 256.000 (figura 22). Estes valores 
demonstram que as proteínas são imunogênicas e que o protocolo é adequado para obtenção de soro hiperimune.

Figura 22 - Presença de anticorpos em soros de camundongos imunizados. Os animais foram semanalmente imunizados intraperitonealmente com $10 \mu \mathrm{g}$ de proteína recombinante na presença de adjuvante hidróxido de alumínio. Os soros obtidos foram recolhidos num pool e seus títulos determinados por ELISA contra a proteína homóloga.

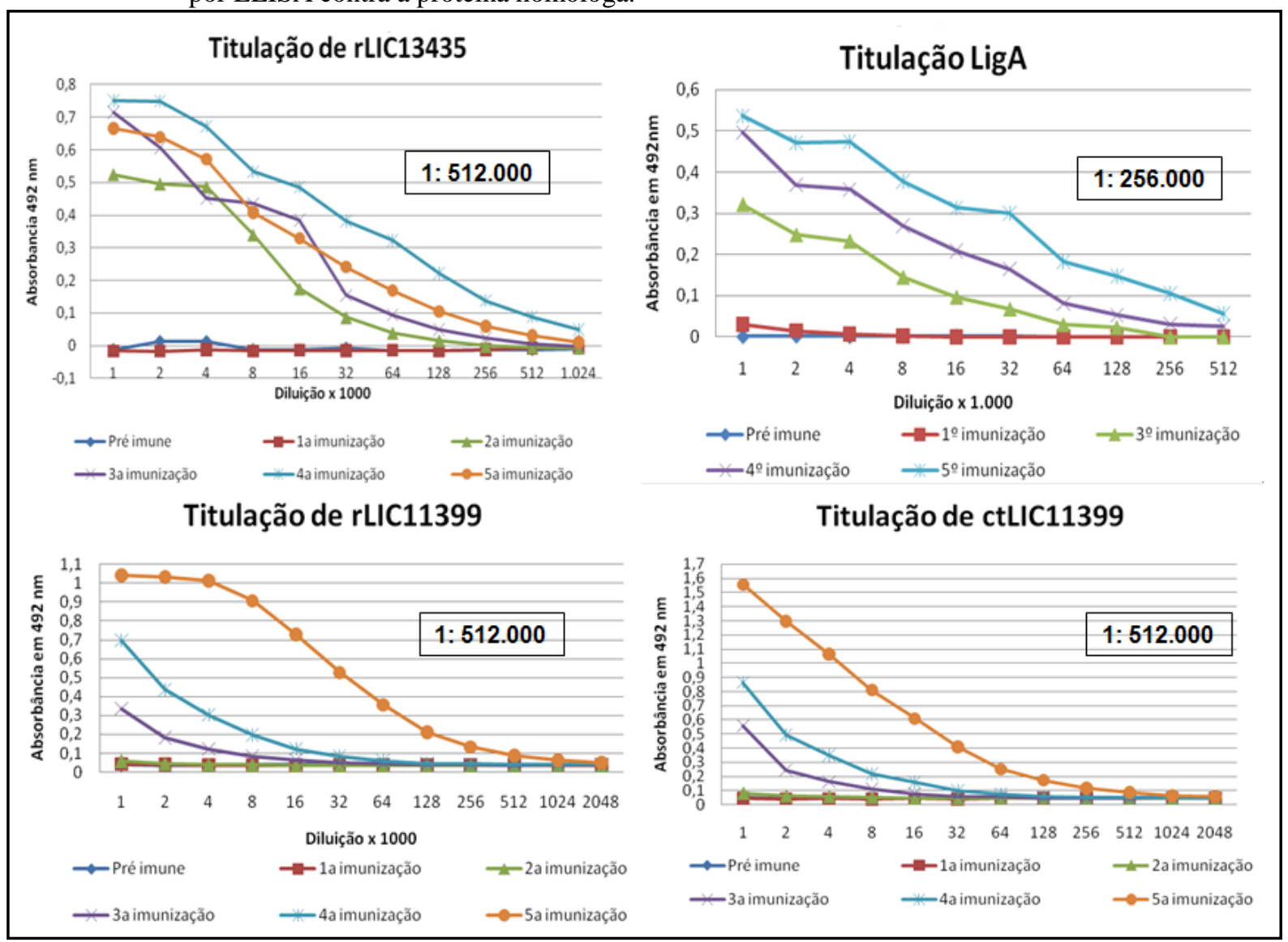

\subsection{Análise de especificidade dos anticorpos gerados por Western blot}

Os anticorpos gerados em camundongo contra as proteínas recombinantes rLIC13435, rLIC11399 e ctLIC11399 foram avaliados quanto a sua especificidade. Para este propósito, um painel contendo variadas proteínas recombinantes de Leptospira interrogans sorovar Copenhageni foi testado com cada anticorpo individualmente.

A especificidade do anticorpo anti-rLIC13435 foi avaliada em um painel contendo aproximadamente $1 \mu \mathrm{g}$ de proteínas recombinantes LipL32 e TlyC. O anticorpo antirLIC13435 reagiu especificamente com a sua respectiva proteína recombinante (figura 23).

A especificidade do anticorpo anti-LIC11399 e anti-ctLIC11399 foi avaliada em um painel contendo aproximadamente $1 \mu \mathrm{g}$ de proteínas recombinantes LipL32, rLIC11399 e 
ctLIC11399. O anticorpo anti-LIC11399 não reconheceu a proteína recombinante LipL32, porém, reagiu com sua respectiva proteína recombinante e também com seu fragmento ctLIC11399, o mesmo aconteceu com o anticorpo anti-ctLIC11399, que não reconheceu a proteína recombinante LipL32, porém reconheceu sua respectiva proteína ctLIC11399 e também rLIC11399 (figura 24). O reconhecimento cruzado reforça a qualidade das proteínas recombinantes purificadas e anticorpos gerados, pois, a seqüência de uma proteína faz parte da outra. O anticorpo anti-LipL32 foi incluído como um controle, pois, é descrita como sendo uma lipoproteína majoritariamente expressa na superfície externa de leptospiras patogênicas e apresentada ao sistema imune humano (89).

Figura 23 - Análise da especificidade do anticorpo gerado contra a proteína rLIC13435. Antisoro gerado contra a proteína recombinante rLIC13435 foi utilizado em um western blot contra um painel com proteínas variadas de Leptospira interrogans sorovar Copenhageni. 1 - Marcador de massa molecular LMW; 2 - LipL32; TlyC; 4 - rLIC13435.

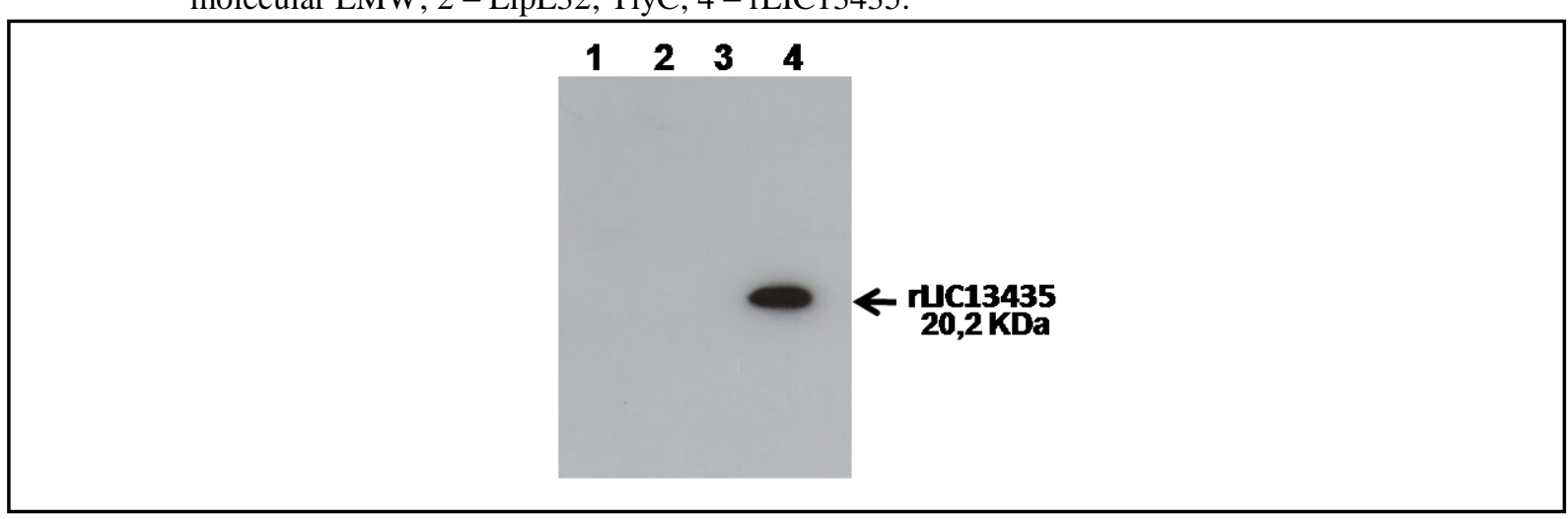

Figura 24 - Análise da especificidade do anticorpo gerado contra a proteína rLIC11399 e ctLIC11399. Antisoro gerado contra as proteínas rLIC11399 e ctLIC11399 foi utilizado em um western blot contra um painel com proteínas variadas de Leptospira interrogans sorovar Copenhageni. 1 Marcador de massa molecular LMW; 2 - rLIC11399; 3 - ctLIC11399; 4 - rLIC13435. Os anticorpos avaliados e um indicador de massa molecular estão indicados.

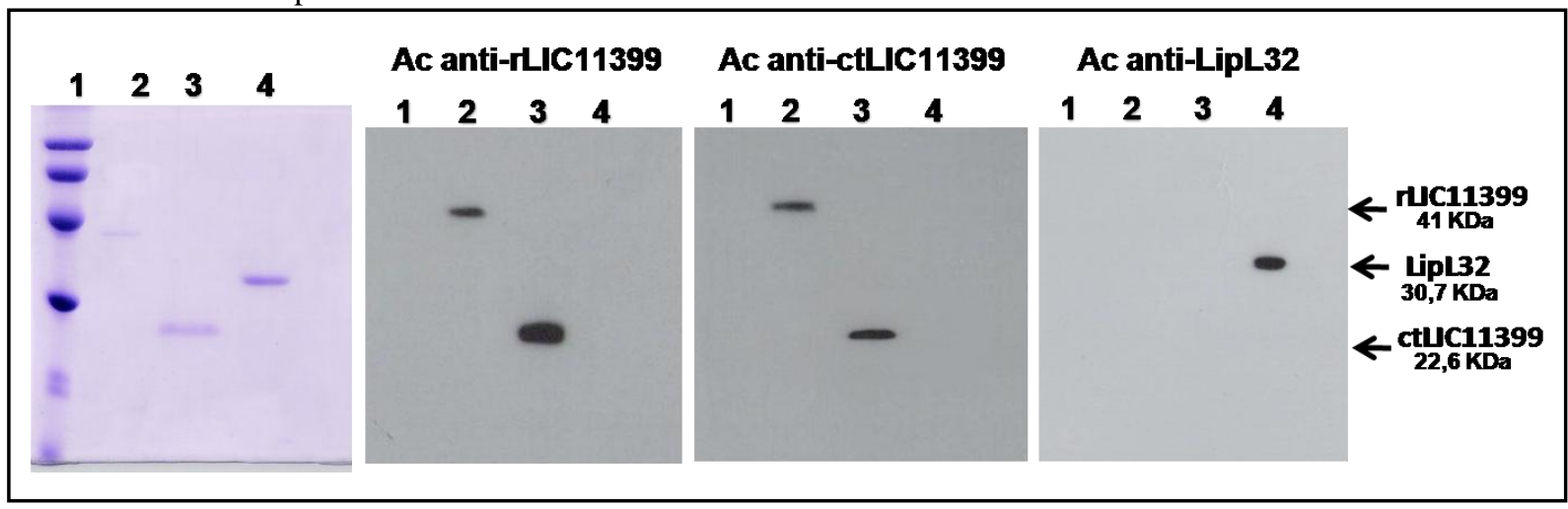




\subsection{Análise da conservação da proteína nativa LIC13435 em Leptospira sp.}

Para a análise da conservação da proteína nativa LIC13435 em extratos de Leptospira $s p$. , foram utilizados os anticorpos gerados em camundongos contra a proteína rLIC13435. Um painel com extratos de 9 sorovares de leptospira patogênicas sendo 8 da espécie $L$. interrogans (sorovares Pomona, Canicola, Copenhageni, Icterohaemorrhagie, Hardjo, Pyrogenes, Autumnalis, Bratislava), 1 da espécie L. kirschneri sorovar Grippotyphosa e 1 espécie de Leptospira saprófita (L. biflexa sorovar Patoc) foi avaliado quanto à presença da proteína nativa por western blot.

Os resultados obtidos indicam que a proteína nativa possivelmente sofre modulação em sua expressão, pois, sua detecção foi bastante variada. Como os resultados não foram conclusivos, não foi possível determinar precisamente se a proteína nativa LIC13435 é expressa por leptospiras em cultivo (dados não apresentados).

\subsection{Análise da conservação da proteína nativa LIC11399 em Leptospira sp.}

Para a análise da conservação da proteína nativa LIC11399 em Leptospira sp. foram utilizados os anticorpos gerados em camundongos contra as proteínas rLIC11399 e ctLIC11399. Um painel com extratos de variadas espécies de leptospiras patogênicas $(L$. interrogans, L. santarosai, L. borgpertesenii, L. kirshneri, L. noguchii) e uma espécie de leptospira saprófita (L. biflexa) foi avaliado quanto à presença da proteína nativa por western blot. Foram testados os seguintes extratos: L. interrogans sorovares Pomona, Canicola, Copenhageni, Icterohaemorrhagie, Hardjo, Pyrogenes, Autumnalis, Bratislava; L. santarosai sorovares Shermani e Batavia; L. borgpertesenii sorovares Castelonis e Javanica; L. kirshneri Cynopteri e Grippotyphosa; L. noguchii sorovar Panama e L. biflexa sorovar Patoc. Os resultados obtidos indicam que a proteína nativa é expressa somente por leptospiras patogênicas, não sendo possível detectar uma banda imunorreativa na região correspondente do extrato de leptospira biflexa (figuras 25, 26 e 27). Além disso, os soros anti-rLIC11399 e anti-ctLIC11399 não só foram capazes de reconhecer a proteína nativa, como também tiveram reconhecimento cruzado, onde o soro anti-rLIC11399 foi capaz de detectar a proteína ctLIC11399 e vice-versa. 
Figura 25 - Detecção da expressão de LIC11399 em cultivos de Leptospira. Antisoro gerado contra a proteína rLIC11399 foi utilizado em um western blot contra um painel de extratos diferentes de Leptospira. Um indicador de massa molecular (em KDa) é mostrado em ambos os lados; 1 Marcador de massa molecular LMW; 2 - L. interrogans sorovar Copenhageni; 3 - L. interrogans sorovar Icterohaemorrhagie; 4 - L. interrogans sorovar Pomona; 5 - L. kirschneri sorovar Grippotyphosa; 6 - L. interrogans sorovar Hardjo; 7 - L. interrogans sorovar Canicola; 8 L.interrogans sorovar Bratislava; 9 - L. interrogans sorovar Autumnalis; 10 - L. interrogans sorovar Pyrogenes; 11 - L. biflexa sorovar Patoc; 12 - rLIC11399; 13 - ctLIC11399.

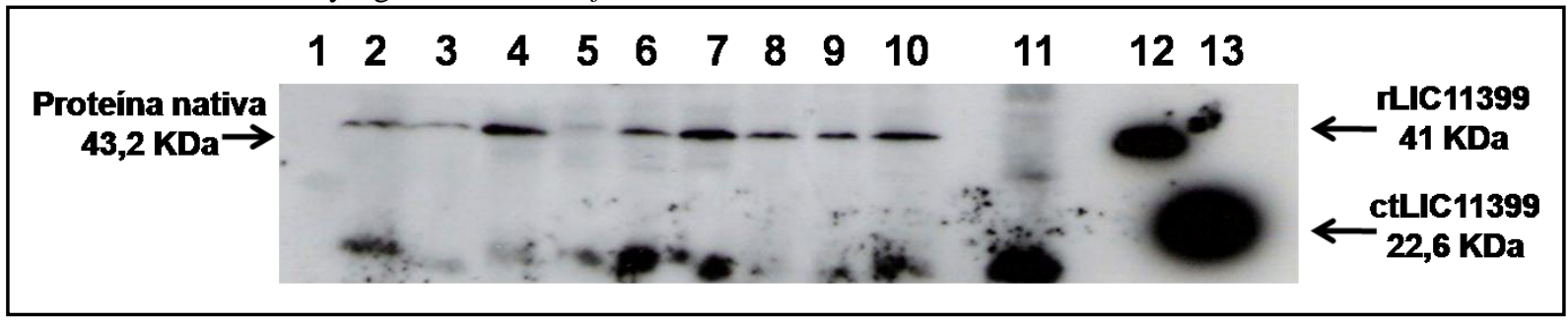

Figura 26 - Detecção da expressão de LIC11399 em cultivos de Leptospira. Antisoro gerado contra ctLIC11399 foi utilizado em um western blot contra um painel de extratos diferentes de Leptospira. Um indexador de massa molecular (em KDa) é mostrado em ambos os lados; $1-L$. interrogans sorovar Copenhageni; 2 - L. interrogans sorovar Icterohaemorrhagie; 3 - L. interrogans sorovar Pomona; 4 - L. kirschneri sorovar Grippotyphosa; 5 - L. interrogans sorovar Hardjo; 6 - L. interrogans sorovar Canicola; 7 - L..interrogans sorovar Bratislava; 8 - L. interrogans sorovar Autumnalis; 9- L. interrogans sorovar Pyrogenes; 10 - L. biflexa sorovar Patoc; 11 - ctLIC11399; 12 - rLIC11399.

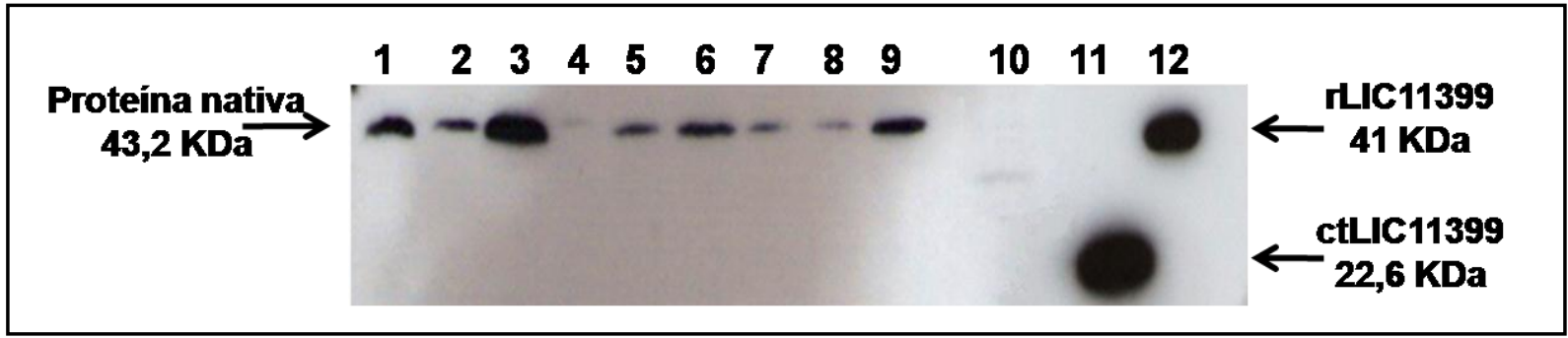

Figura 27 - Detecção da expressão de LIC11399 em cultivos de Leptospira. Antisoro gerado contra rLIC11399 foi utilizado em um western blot contra um painel de extratos diferentes de Leptospira. Um indexador de massa molecular (em KDa) é mostrado em ambos os lados; $1-L$. interrogans sorovar Copenhageni; 2 - L. interrogans sorovar Pomona; 3 - L. santarosai sorovar Shermani; 4 - L santarosai sorovar Batavia; 5 - L. borgpertesenii sorovar Castelonis; $6-L$. borgpertesenii sorovar Javanica; 7 - L. kirshneri sorovar Cynopteri; 8 - L. kirshneri sorovar Grippotyphosa; 9 - L. noguchii sorovar Panama; 10 - rLIC11399.

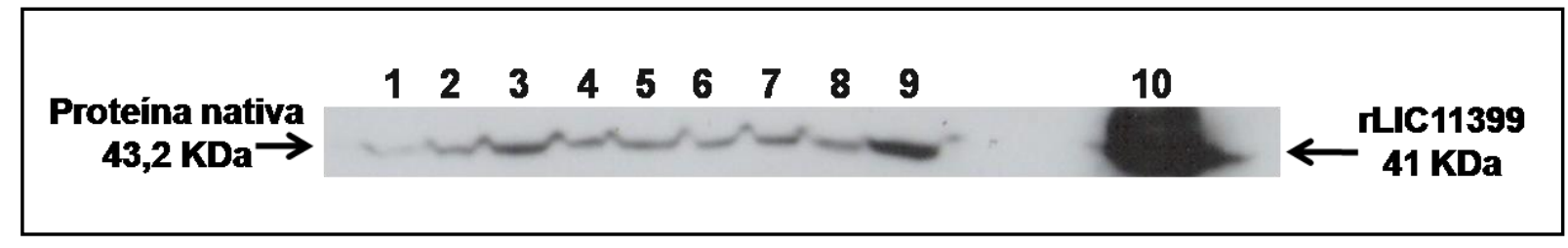




\subsection{Detecção da proteína nativa LIC13435 durante a infecção por leptospira em hospedeiros}

Soro de hamster infectado por L. interrogans sorovar Copenhageni foi avaliado quanto a presença de anticorpos do tipo IgG dirigidos contra a proteína rLIC13435 e, não foi evidenciado nenhuma banda imunorreativa (dados não apresentados).

Soros de pacientes humanos infectados foram avaliados quanto a presença de anticorpos do tipo IgG e IgM dirigidos contra a proteína rLIC13435 e, não foi evidenciado nenhuma banda imunorreativa. A figura 28 representa o resultado da detecção de anticorpos do tipo IgG em pacientes humanos. A proteína LipL32 foi incluída no experimento como controle positivo.

Figura 28 - Detecção da proteína nativa LIC13435 durante a infecção por leptospira em humanos. 1

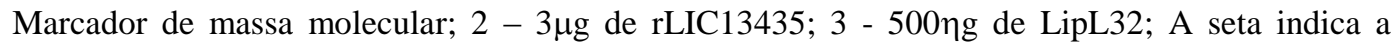
reatividade do soro testado com a proteína LipL32 recombinante.

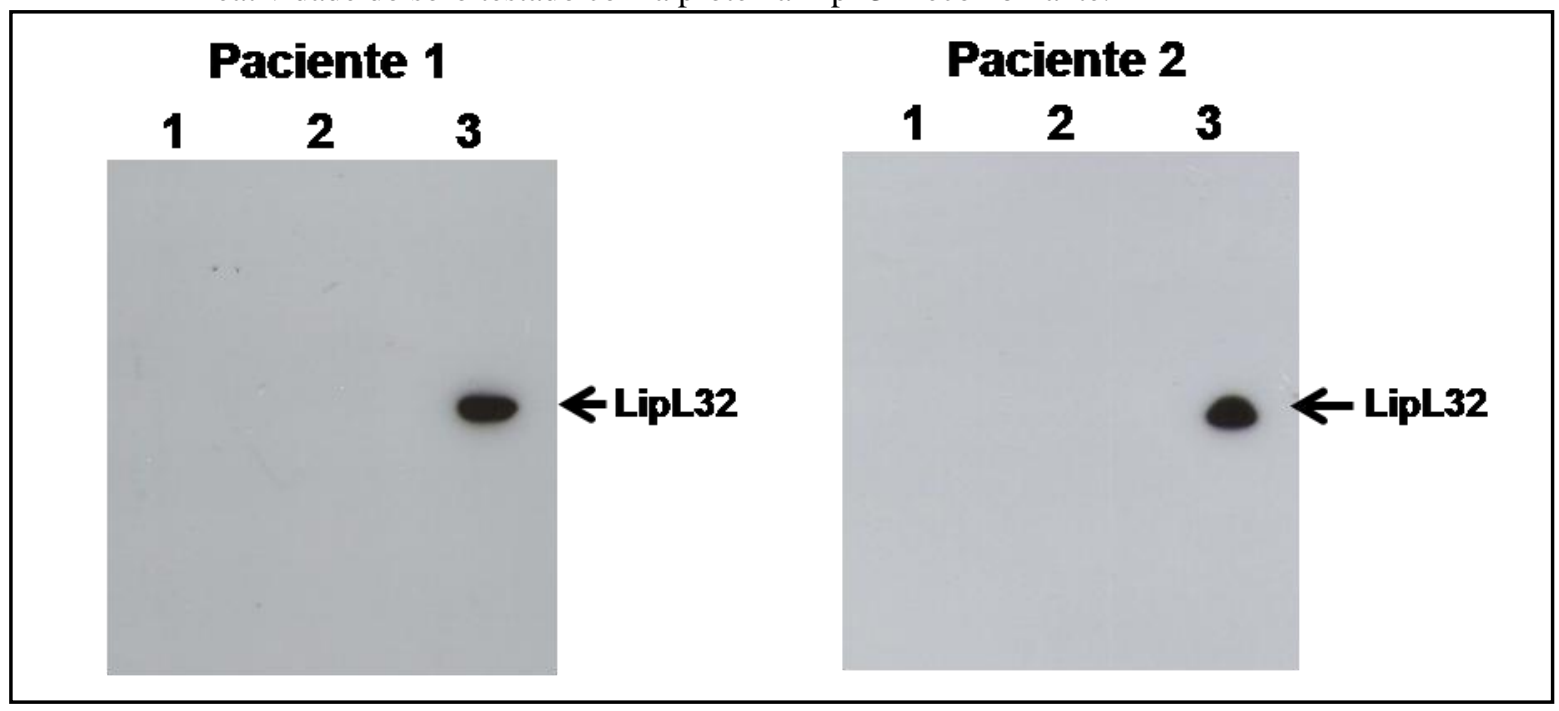

\subsection{Detecção da proteína nativa LIC11399 durante a infecção por leptospira em hospedeiros}

Soros de hamsters e soros de pacientes humanos infectados foram avaliados quanto à presença de anticorpos do tipo IgG dirigidos contra as proteína rLIC11399 e ctLIC11399. O soro de hamster foi coletado 10 dias após um desafio com Leptospira interrogans sorovar Copenhageni virulento. Os soros de pacientes humanos infectados foram coletados durante a segunda semana de infecção por leptospira (fase imune). Em ambos os casos foi possível 
detectar a presença de anticorpos do tipo IgG dirigidos contra rLIC11399 e / ou ctLIC11399. Como controle positivo foi utilizado a proteína LipL32, e como controle negativo, utilizamos a proteína recombinante rLIC13435 (figuras 29 e 30). Informações dos soros de pacientes testados estão na tabela 5 .

Com o intuito de saber se a proteína LIC11399 é apresentada ao sistema imune do hospedeiro durante a fase aguda da infecção, procuramos por anticorpos do tipo IgM em soros da primeira semana de infecção dos mesmos pacientes. Não foi possível evidenciar anticorpos do tipo IgM dirigidos contra a proteína rLIC11399 (dados não apresentados).

Figura 29 - Detecção de anticorpos do tipo IgG dirigido contra as proteínas rLIC11399 e ctLIC11399 em soro de hamster com leptospirose. 1 - Marcador de massa molecular; 2 - 3 $\mu \mathrm{g}$ de ctLIC11399; 3 - $3 \mu \mathrm{g}$ de rLIC11399; $4-3 \mu \mathrm{g}$ de rLIC13435.

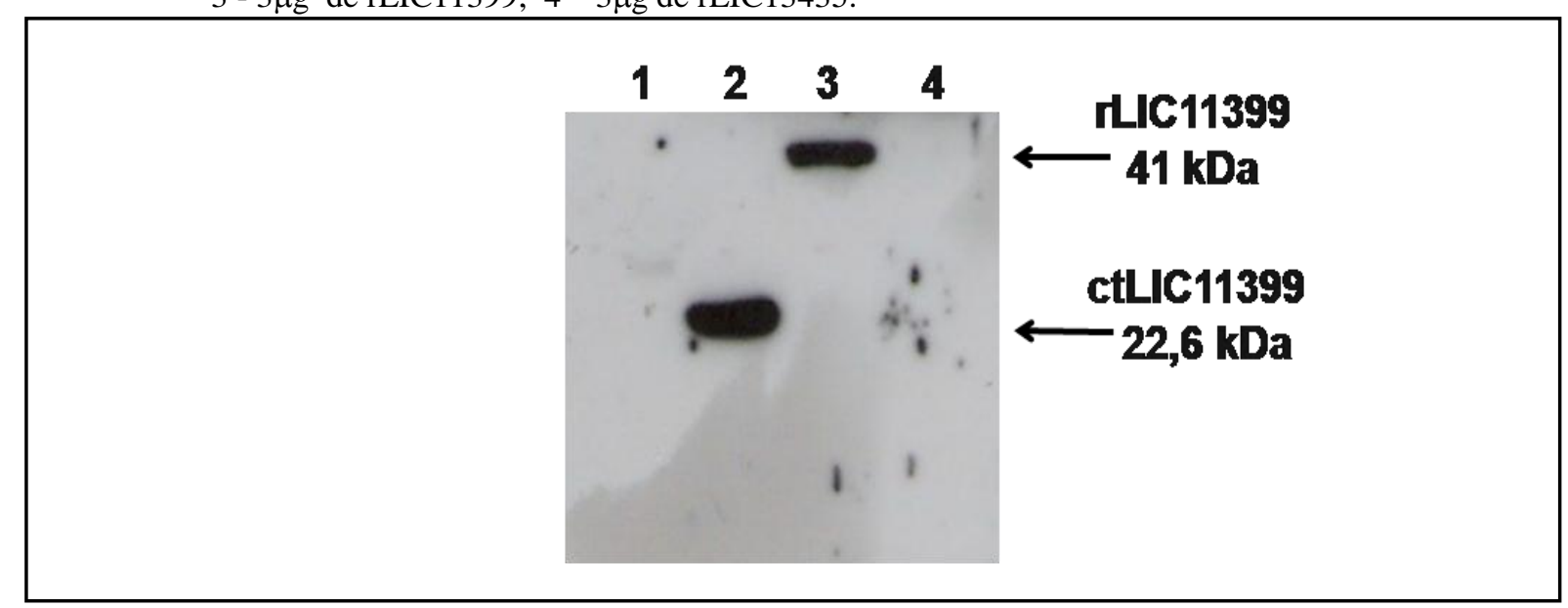


Figura 30 - Detecção de anticorpos do tipo IgG dirigido contra a proteína rLIC11399 em soros de

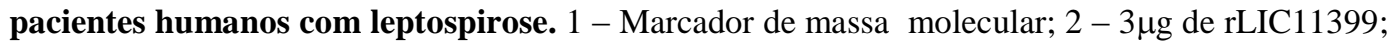
3 - $3 \mu \mathrm{g}$ de rLIC13435; 4 - 500ng de LipL32

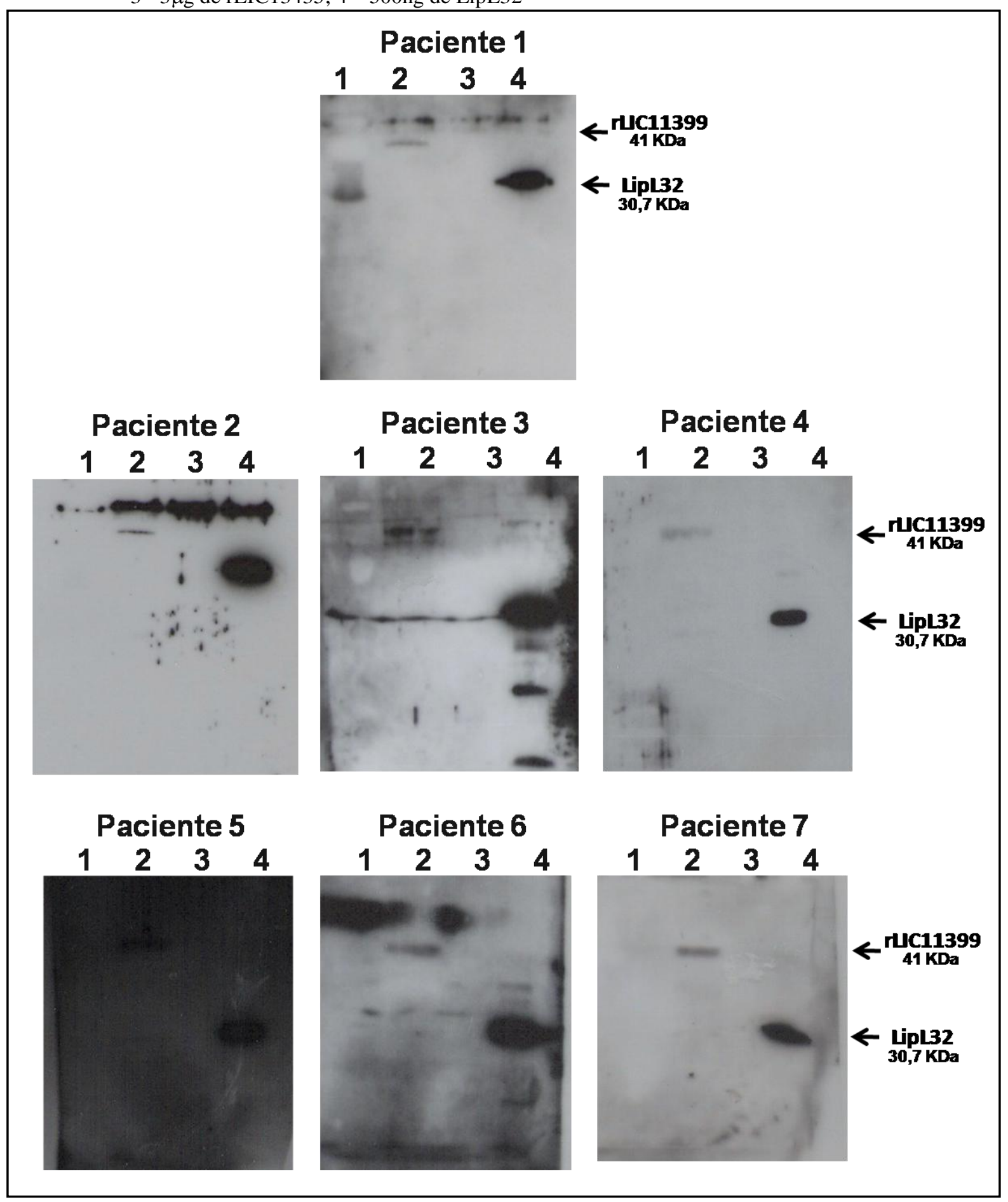


Tabela 5 - Soro infectante e título de MAT de 7 soros de pacientes com leptospirose

\begin{tabular}{cccc}
\hline Paciente & Número do soro & Reatividade sorovar Leptospira & $\begin{array}{c}\text { Título inverso } \\
\text { do MAT }\end{array}$ \\
\hline \multirow{2}{*}{1} & $1334 / 07$ & Negativo & Negativo \\
& $16 / 08$ & Icterohaemorrhagiae / Copenhageni & 6.400 \\
\hline \multirow{2}{*}{2} & $641 / 07$ & Icterohaemorrhagiae / Copenhageni & 200 \\
& $670 / 07$ & Icterohaemorrhagiae / Copenhageni & 6.400 \\
\hline \multirow{2}{*}{3} & $05 / 08$ & Negativo & Negativo \\
& $30 / 08$ & Icterohaemorrhagiae / Copenhageni & 3.200 \\
\hline \multirow{2}{*}{5} & $1235 / 07$ & Icterohaemorrhagiae & 100 \\
& $1287 / 07$ & Icterohaemorrhagiae & 12.800 \\
\hline \multirow{2}{*}{6} & $682 / 07$ & Inconclusivo & 800 \\
& $727 / 07$ & Cynopteri & 25.600 \\
\hline \multirow{2}{*}{7} & $124 / 07$ & Cynopteri & 200 \\
& $670 / 07$ & Icterohaemorrhagiae & 6.400 \\
\hline
\end{tabular}

\subsection{Detecção da proteína nativa LIC11399 secretada em meio de cultura}

Além dos domínios presentes na proteína LIC11399, as análises in sílico também revelaram a presença de um peptídeo sinal, sugerindo que a mesma possa ser secretada. Estudos de proteínas homólogas de outros microrganismos relataram a secreção destas proteínas para o ambiente externo $(149,150)$. Baseado nesses fatos, procuramos saber se a proteína LIC11399 nativa é secretada pela bactéria. Para isso, o sobrenadante de cultivos de $L$. interrogans sorovar Copenhageni de dias variados foi imunoprecipitado com o soro antirLIC11399 gerado em camundongo. O material imunoprecipitado foi aplicado em um gel de poliacrilamida SDS-PAGE $12 \%$ para realização posterior de Western blot. Para evitar a detecção de imunoglobulinas (cadeia leve e pesada) de camundongo, utilizamos o soro antirLIC11399 gerado em hamster como anticorpo primário e, como anticorpo secundário, utilizamos IgG de cabra anti IgG de hamster, conjugado a peroxidase. A revelação da membrana indica que a proteína nativa LIC11399 é secretada para meio de cultivo durante o crescimento da leptospira (figura 31). 
Figura 31 - Detecção da proteína nativa LIC11399 secretada por leptospiras. O sobrenadante da cultura de leptospiras, de variados estágios de crescimento, foi imunoprecipitado com anticorpo antirLIC11399 gerado em camundongo. O Western-blot foi realizado com anticorpo anti-rLIC11399 gerado em hamster. 1 - Marcador de massa molecular; $2-1^{\circ}$ dia; $3-3^{\circ}$ dia; $4-5^{\circ}$ dia; $5-7^{\circ}$ dia; $6-10^{\circ}$ dia; $7-200$ ng de rLIC11399.

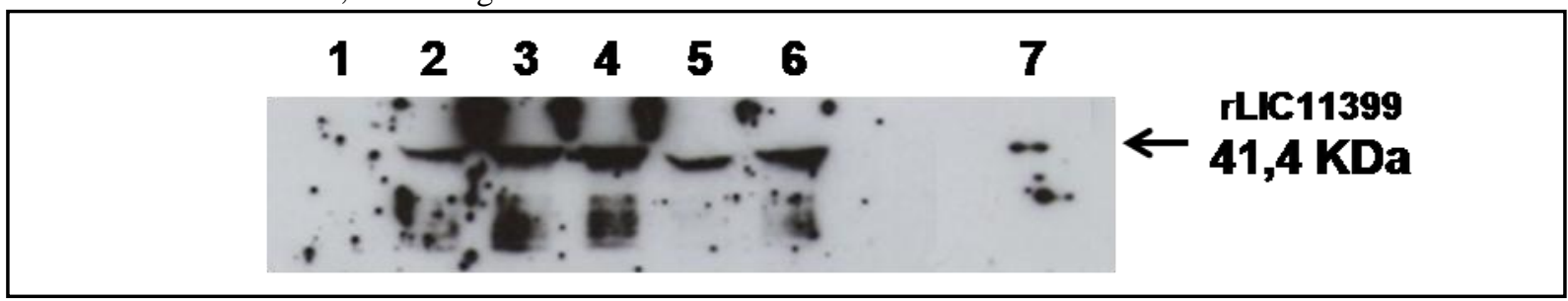

\subsection{Avaliação da capacidade das proteínas rLIC13435 e rLIC11399 de interagir com componentes de matriz extracelular (MEC)}

A interação de patógenos com componentes de matriz extracelular pode desempenhar um papel importante na colonização dos tecidos do hospedeiro. A aderência aos tecidos é mediada por adesinas, proteínas expostas na superfície bacteriana, expressas pelos microorganismos durante a infecção. O bloqueio da interação dessas adesinas com os tecidos do hospedeiro pode ser uma estratégia efetiva contra a infecção bacteriana. Assim sendo, as proteínas rLIC13435 e rLIC11399 foram avaliadas quanto a sua capacidade de interagir com componentes de MEC.

Para este ensaio, foram utilizados os anticorpos gerados em camundongo contra ambas as proteínas purificadas e foram testados os seguintes substratos: fibronectina plasmática, fibronectina celular, laminina e colágeno tipo IV. Como controle positivo foi utilizado a proteína recombinante $\mathrm{TlyC}$ que se liga especificamente à laminina, colágeno tipo IV e à fibronectina plasmática (154). Como controle negativo foi utilizado fetuína. As proteínas rLIC13435 e rLIC11399 não apresentaram interação aos MEC com significância estatística em relação ao controle fetuína (figura 32). Os experimentos foram realizados 3 vezes, todos em triplicata. 
Figura 32 - Adesão de rLIC13435 e rLIC11399 a componentes da MEC. Poços de microplacas foram revestidos com um micrograma de cada componente da MEC e incubados com $1 \mu \mathrm{g}$ de cada proteína recombinante. A detecção das proteínas aderidas foi feita por ELISA usando os soros anti-rLIC11399, anti-rLIC13435 e anti-TlyC. Os dados representam a média de 3 experimentos independentes, cada um realizado em triplicata. A adesão das proteínas recombinantes aos componentes de matriz extra celular foram comparadas com a ligação ao controle fetuína através do teste T-Student (*, $\mathrm{P}<0,0001)$.

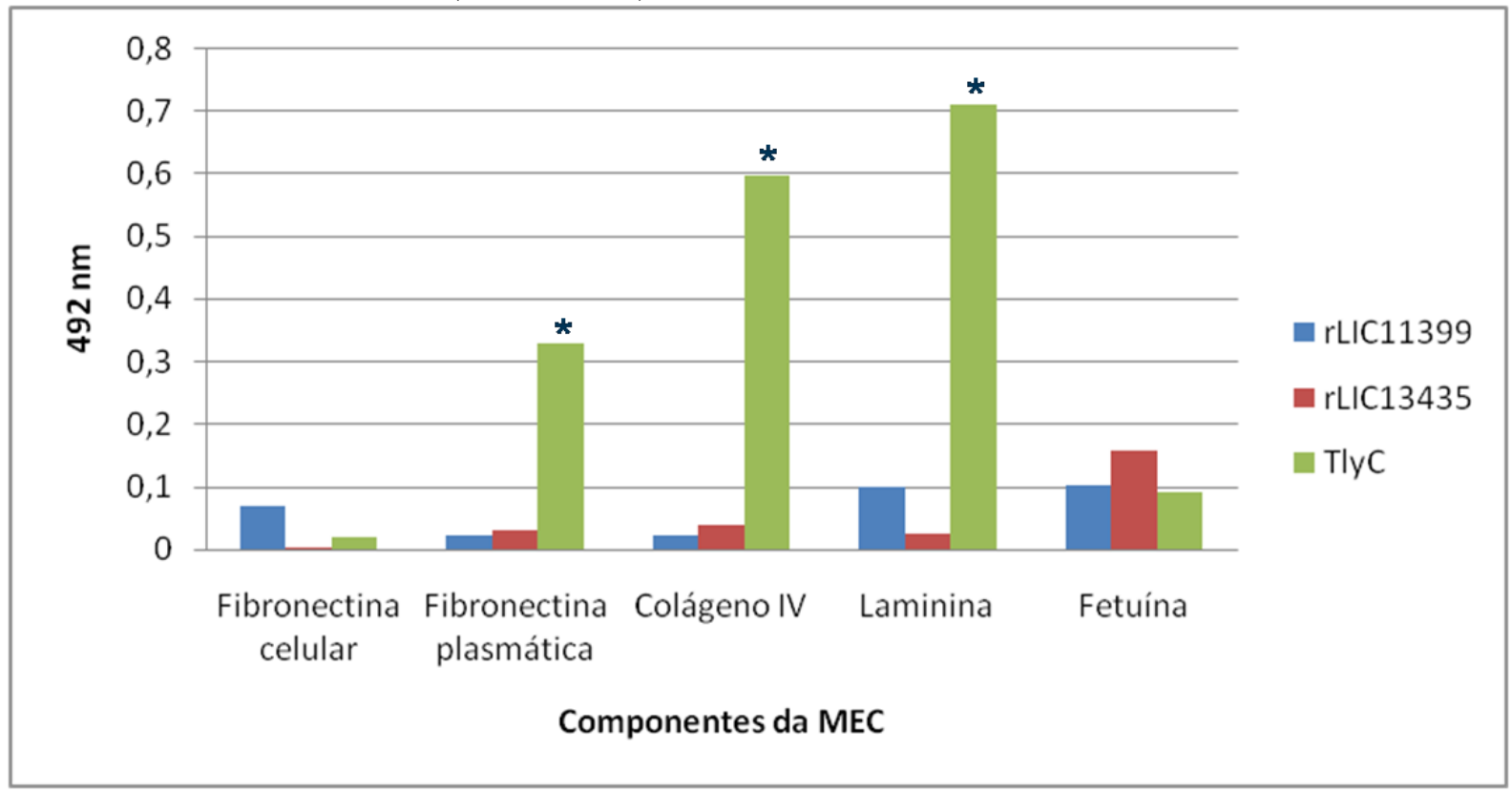

\subsection{Avaliação da atividade elastinolítica das proteínas recombinantes rLIC11399 e ctLIC11399}

Baseado nas análises dos domínios presentes no gene lic11399 e na semelhança ao domínio metaloprotease de LytM descrito por Odintsov (135), as proteínas recombinantes rLIC11399, ctLIC11399 e ctLytM foram avaliadas quanto a capacidade de degradar elastina. A proteína LipL 32 foi acrescentada ao ensaio como controle de proteína recombinante expressa pelo mesmo sistema heterólogo de expressão e purificação que não deveria hidrolizar a elastina. Um miligrama do substrato Elastina-Congo Red (Sigma) foi incubado com concentrações crescentes de proteína por aproximadamente 15 horas. Elastase pancreática porcina comercial (Sigma) foi utilizada como controle positivo e $15 \mathrm{mM}$ de quelante EDTA foi utilizado para avaliar a inibição da atividade enzimática. A densidade ótica da reação foi normalizada com um controle onde não foi adicionado nenhuma proteína ao substrato Elastina-Congo Red. Podemos observar na tabela 06 e 07 que a proteína ctLytM diferentemente do esperado, não apresentou atividade proteolítica sobre o substrato Elastina Congo Red. Em experimentos independentes, foi possível detectar atividade proteolítica das proteínas rLIC11399 e ctLIC11399 sobre o substrato e, a adição de EDTA inibiu essa 
atividade. A densidade ótica máxima obtida pela degradação do substrato pela elastase comercial foi de aproximadamente 0,6 .

A proteína LipL32 não apresentou atividade. As figuras 33 e 34 mostram o resultado de ensaios independentes de proteólise com as proteínas ctLIC11399, LipL32, o controle negativo e o controle positivo sobre o substrato Elastin-Congo Red. A figura 35 mostra o resultado de um ensaio de proteólise com ctLytM sobre o mesmo substrato.

Tabela 6 - Atividade proteolítica sobre o substrato Elastina-Congo Red. Densidade ótica referente à quantidade de degradação do substrato.

\begin{tabular}{ccc}
\hline Amostra & Concentração & O.D. 495 \\
\hline Branco & ---- & 0 \\
\hline $\begin{array}{c}\text { Controle positivo Elastase } \\
\text { comercial }\end{array}$ & $\sim 20$ unidades & 0,6 \\
& & \\
\hline & $20 \mathrm{mM}$ & 0 \\
ctLytM $(1,6 \mathrm{mg} / \mathrm{mL})$ & $14 \mathrm{mM}$ & 0 \\
ctLytM + EDTA & $7 \mathrm{mM}$ & 0 \\
ctLIC11399 $(0,4 \mathrm{mg} / \mathrm{mL})$ & $15 \mathrm{mM}$ & 0,383 \\
ctLIC11399 + EDTA & $10 \mathrm{mM}$ & 0,165 \\
rLIC11399 $(0,15 \mathrm{mg} / \mathrm{mL})$ & $5.2 \mathrm{mM}$ & 0,131 \\
rLIC11399 + EDTA & $15 \mathrm{mM}+15 \mathrm{mM}$ EDTA & 0 \\
\hline LipL32 & $3.3 \mathrm{mM}$ & 0,125 \\
& $2.2 \mathrm{mM}$ & 0 \\
& $1.1 \mathrm{mM}$ & 0 \\
\hline
\end{tabular}


Tabela 7 - Atividade proteolítica sobre o substrato Elastina-Congo Red. Densidade ótica referente à quantidade de degradação do substrato.

\begin{tabular}{ccc}
\hline Amostra & Concentração & O.D. 495 \\
\hline Branco & & 0 \\
\hline $\begin{array}{c}\text { Controle positivo Elastase } \\
\text { comercial }\end{array}$ & $\sim 20$ unidades & 0,6 \\
\hline \multirow{2}{*}{ tLytM $(1,6 \mathrm{mg} / \mathrm{mL})$} & $20 \mathrm{mM}$ & 0 \\
& $14 \mathrm{mM}$ & 0 \\
ctLytM + EDTA & $7 \mathrm{mM}$ & 0 \\
& $20 \mathrm{mM}+15 \mathrm{mM}$ EDTA & 0 \\
ctLIC11399 $(0,3 \mathrm{mg} / \mathrm{mL})$ & $11.5 \mathrm{mM}$ & 0,293 \\
& $7.6 \mathrm{mM}$ & 0,097 \\
ctLIC11399+ EDTA & $3.8 \mathrm{mM}$ & 0 \\
rLIC11399 $(0,4 \mathrm{mg} / \mathrm{mL})$ & $11.5 \mathrm{mM}+15 \mathrm{mM}$ EDTA & 0,117 \\
rLIC11399 + EDTA & $8.9 \mathrm{mM}$ & 0 \\
LipL32 & $5.9 \mathrm{mM}$ & 0 \\
& $3.0 \mathrm{mM}$ & 0 \\
\hline
\end{tabular}

Figura 33 - Imagem representativa de um ensaio de proteólise de ctLIC11399 e LipL32 sobre o subtrato Elastina-Congo Red. Um miligrama do substrato Elastina-Congo Red foi incubado com concentrações crescentes de proteína por aproximadamente 14 horas. Elastase pancreática porcina comercial foi utilizada como controle positivo e não foi adicionado nada no controle negativo.

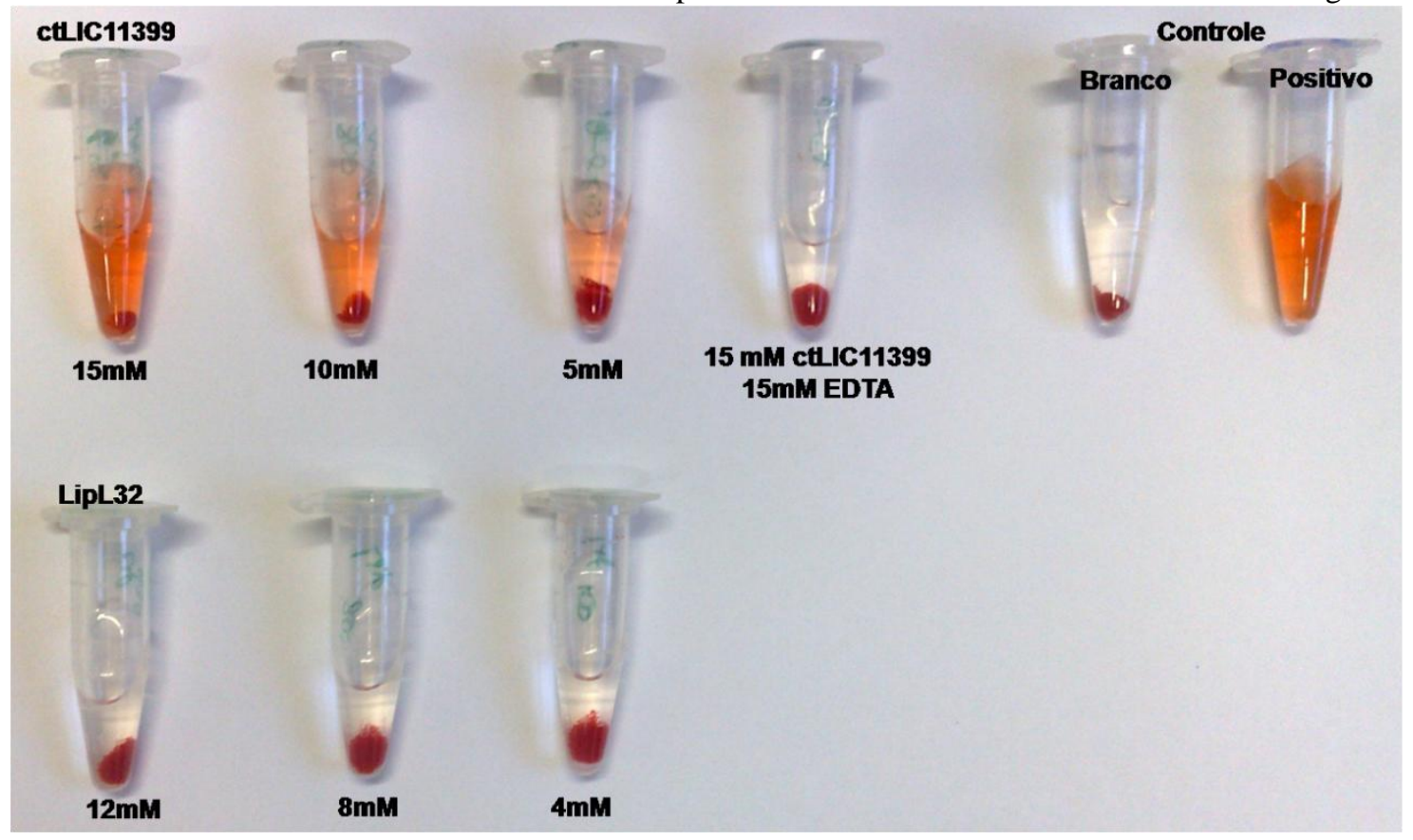


Figura 34 - Imagem representativa de um ensaio de proteólise de ctLIC11399 e LipL32 sobre o subtrato Elastina-Congo Red. Um miligrama do substrato Elastina-Congo Red foi incubado com concentrações crescentes de proteína por aproximadamente 14 horas. Elastase pancreática porcina comercial foi utilizada como controle positivo e não foi adicionado nada no controle negativo.

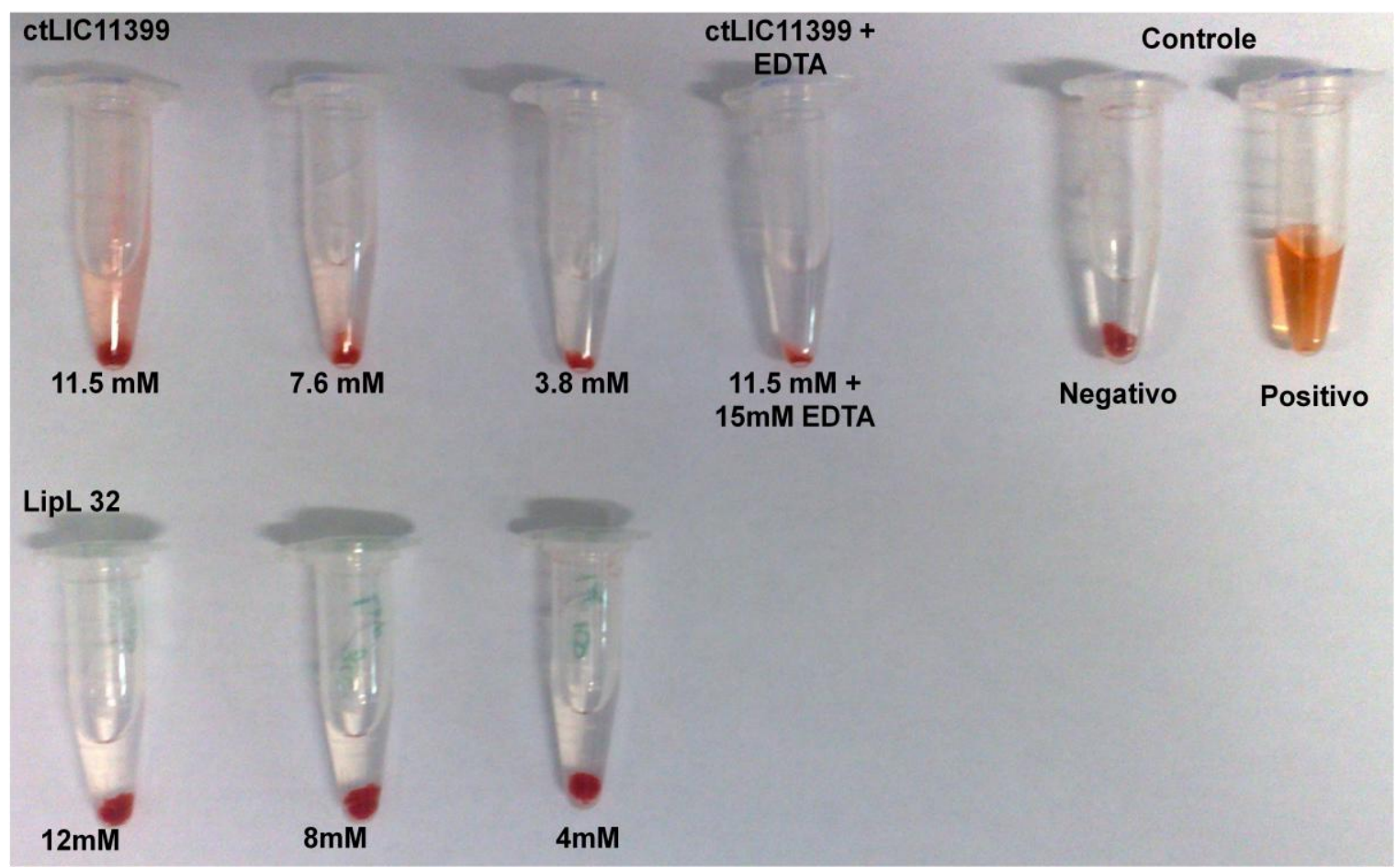

Figura 35 - Imagem representativa de um ensaio de proteólise de ctLytM sobre o subtrato Elastina-Congo Red. Um miligrama do substrato Elastina-Congo Red foi incubado com concentrações crescentes de proteína por aproximadamente 14 horas. Elastase pancreática porcina comercial foi utilizada como controle positivo e não foi adicionado nada no controle negativo.

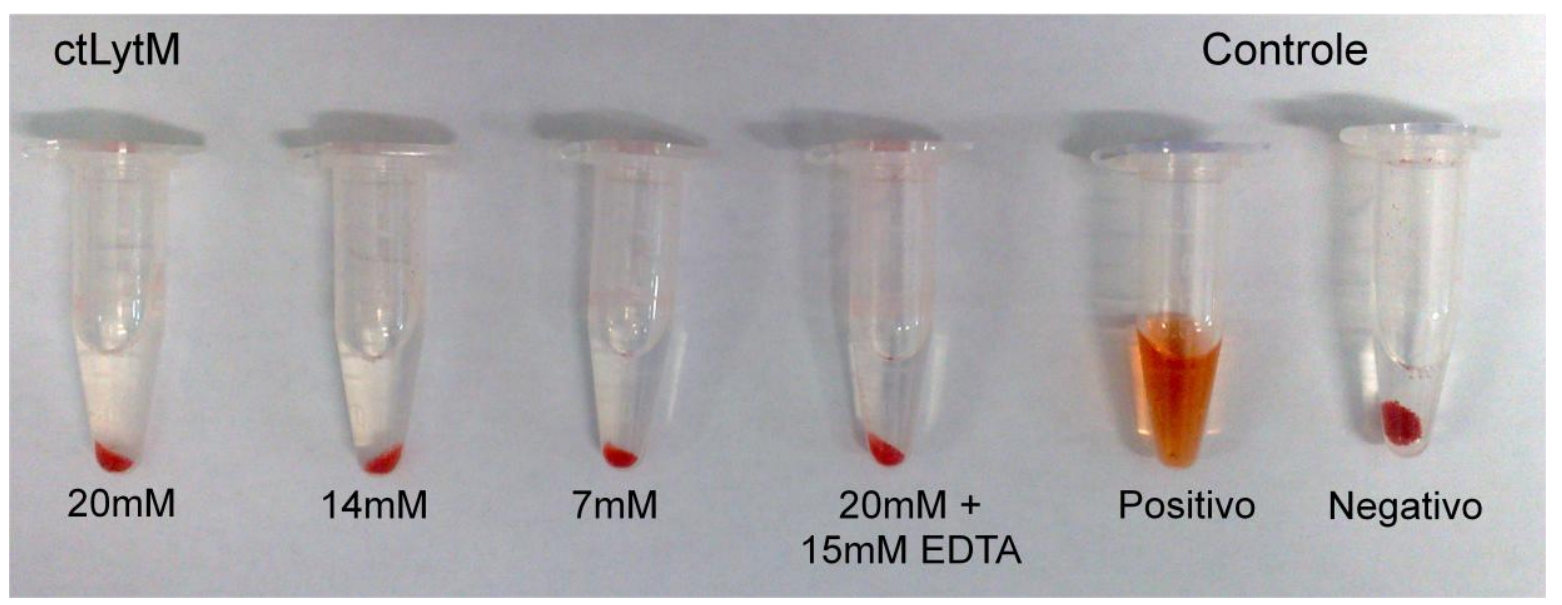

\subsection{Avaliação da atividade elastinolítica de ctLIC11399 por zimografia}

Géis de SDS-PAGE foram co-polimerizados com elastina solúvel em uma concentração final de $1 \mathrm{mg} / \mathrm{mL}$. Concentrações decrescentes da proteína ctLIC11399 
purificada foram aplicadas no gel na presença ou não de quelante (EDTA) ou inibidor de protease (PMSF) em condições não desnaturantes. Elastase pancreática porcina comercial (Sigma) foi utilizada como controle positivo. Após a eletroforese, os géis foram incubados a $37{ }^{\circ} \mathrm{C}$ por 48 horas. A atividade proteolítica foi avaliada após coloração com o corante Comassie Brilliant Blue e descoloração até o aparecimento de áreas de atividade proteolítica (regiões mais claras no gel, contrastando com o fundo azul (resultado da digestão do substrato presente na matriz poliacrilamida-elastina). Este ensaio foi realizado três vezes com amostras de diferentes purificações. A figura 36 é representativa de um ensaio de avaliação proteolítica por zimografia.

A proteína ctLIC11399 não apresentou atividade proteolítica sobre o substrato presente no gel.

Figura 36 - Imagem representativa de um ensaio de zimografia de ctLIC11399. 1 - Marcador de peso molecular; 2 a 5 - 25 $\mu \mathrm{g}, 20 \mu \mathrm{g}, 15 \mu \mathrm{g}$ e $10 \mu \mathrm{g}$ de ctLIC11399 respectivamente; 6 - $20 \mu \mathrm{g}$ de

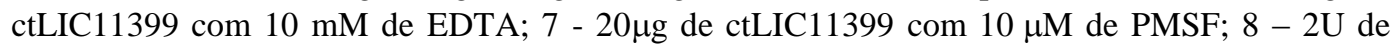
elastase porcina comercial.

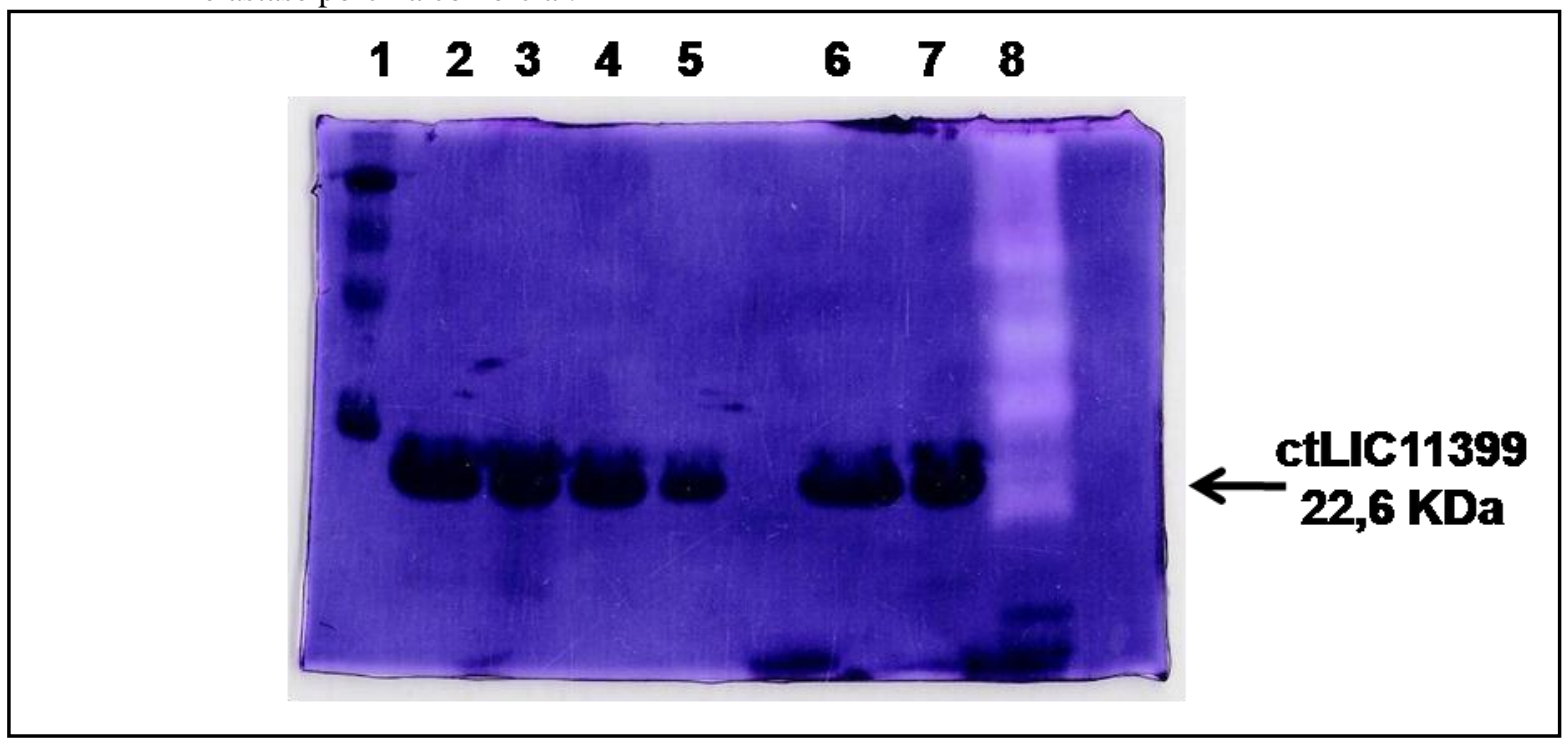

\subsection{Ensaio de proteção contra desafio homólogo}

Nos ensaios de imunização e desafio em modelo animal utilizados para leptospirose, grupos de 10 hamsters foram imunizados subcutaneamente com as proteínas recombinantes e desafiados com Leptospira interrogans sorovar Copenhageni virulentos para avaliar a capacidade dos antígenos de conferir proteção. Os animais também foram vacinados com a vacina comercial (Pfizer), PBS ou não foram imunizados. A imunização com a proteína ctLigA foi incluída nos experimentos como controle de antígeno capaz de conferir proteção 
aos animais imunizados. Os animais vacinados que sobreviveram até 21 dias após o desafio foram sacrificados e tiveram seus rins coletados para análise quanto à presença de leptospiras in vitro.

Em três ensaio independentes, os animais imunizados com a proteína rLIC13435 não sobreviveram ao desafio com Leptospira interrogans sorovar Copenhageni virulentos. Como esperado, $100 \%$ dos animais imunizados com ctLigA e a vacina comercial sobreviveram ao desafio. Não houveram sobreviventes entre os animais imunizados com PBS ou não imunizado (figura 37).

Figura 37 - Análise da porcentagem de sobrevivência dos grupos de animais vacinados e desafiados. Gráfico representativo de um dos ensaios de desafio. Os animais imunizados com rLIC13435, ctLigA, PBS, vacina comercial ou não imunizados foram desafiados com a cepa L. interrogans sorovar Copenhageni virulento e observados por 21 dias.

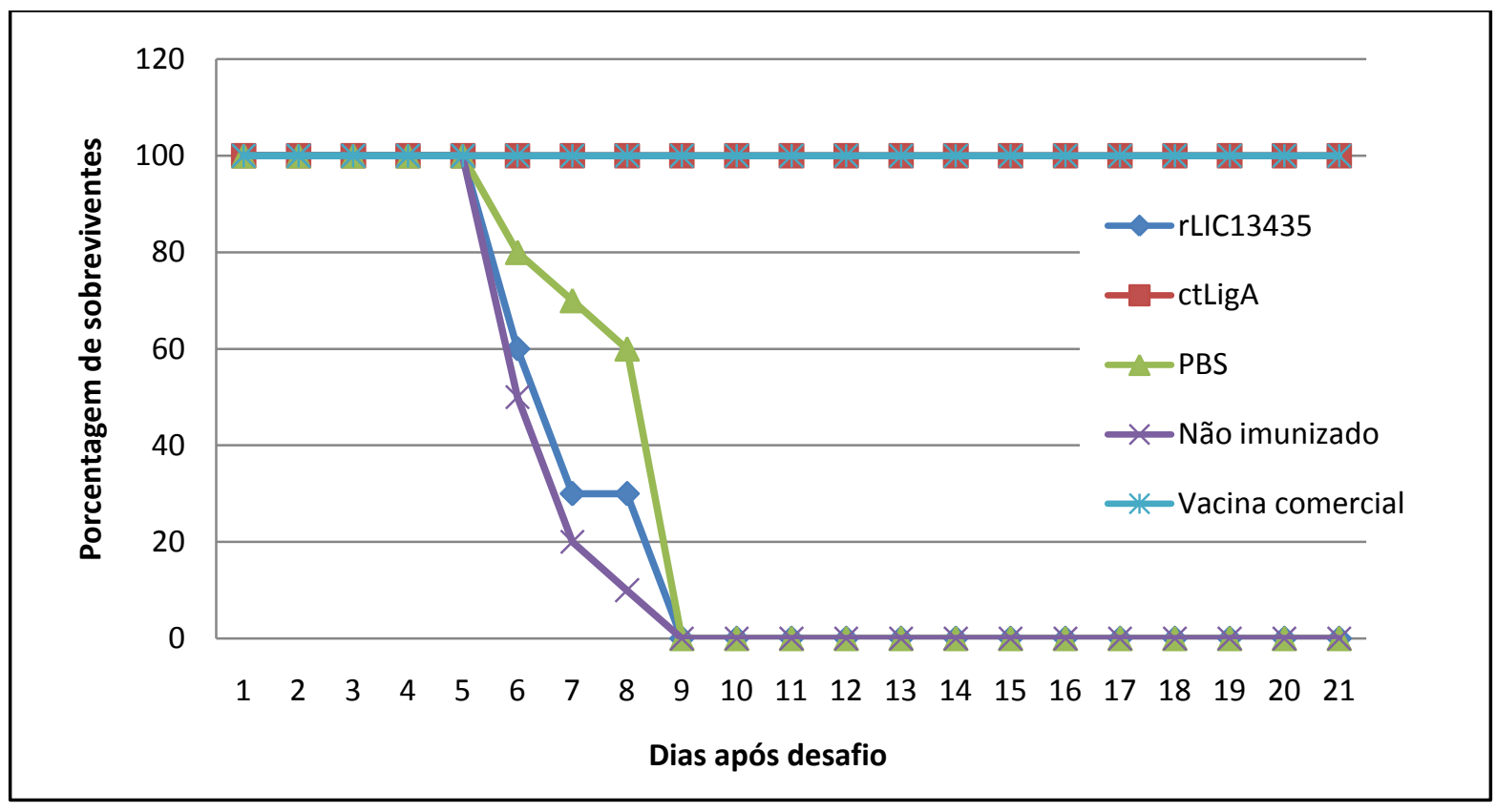

Em dois experimentos independentes, a imunização com rLIC11399 foi capaz de conferir proteção em $30 \%$ dos animais, enquanto que 100\% dos animais imunizados com ctLigA e a vacina comercial sobreviveram ao desafio. Não houve sobreviventes entre os animais imunizados com PBS ou não imunizados (figura 38 e 39). Os animais vacinados que sobreviveram até 21 dias após o desafio foram sacrificados e tiveram seus rins coletados para análise quanto à presença de leptospiras in vitro. Na tabela 8, pode-se verificar que não foi possível detectar leptospiras no cultivo do macerado renal dos animais imunizados com a vacina comercial, enquanto que foi constatada a presença de bactérias no cultivo do macerado dos rins dos animais imunizados com rLIC11399 e ctLigA. A análise dos níveis de IgG por 
ELISA, dos soros coletados dos animais imunizados, mostrou que as proteínas rLIC11399 e ctLigA geraram respectivamente títulos de anticorpos em torno de 16.000 e 32.000 (dados não apresentados).

Figura 38 - Análise da porcentagem de sobrevivência dos grupos de animais vacinados e desafiados. Os animais imunizados com rLIC11399, ctLigA, PBS, vacina comercial ou não imunizados foram desafiados com a cepa $L$. interrogas sorovar Copenhageni virulento e observados por 21 dias.

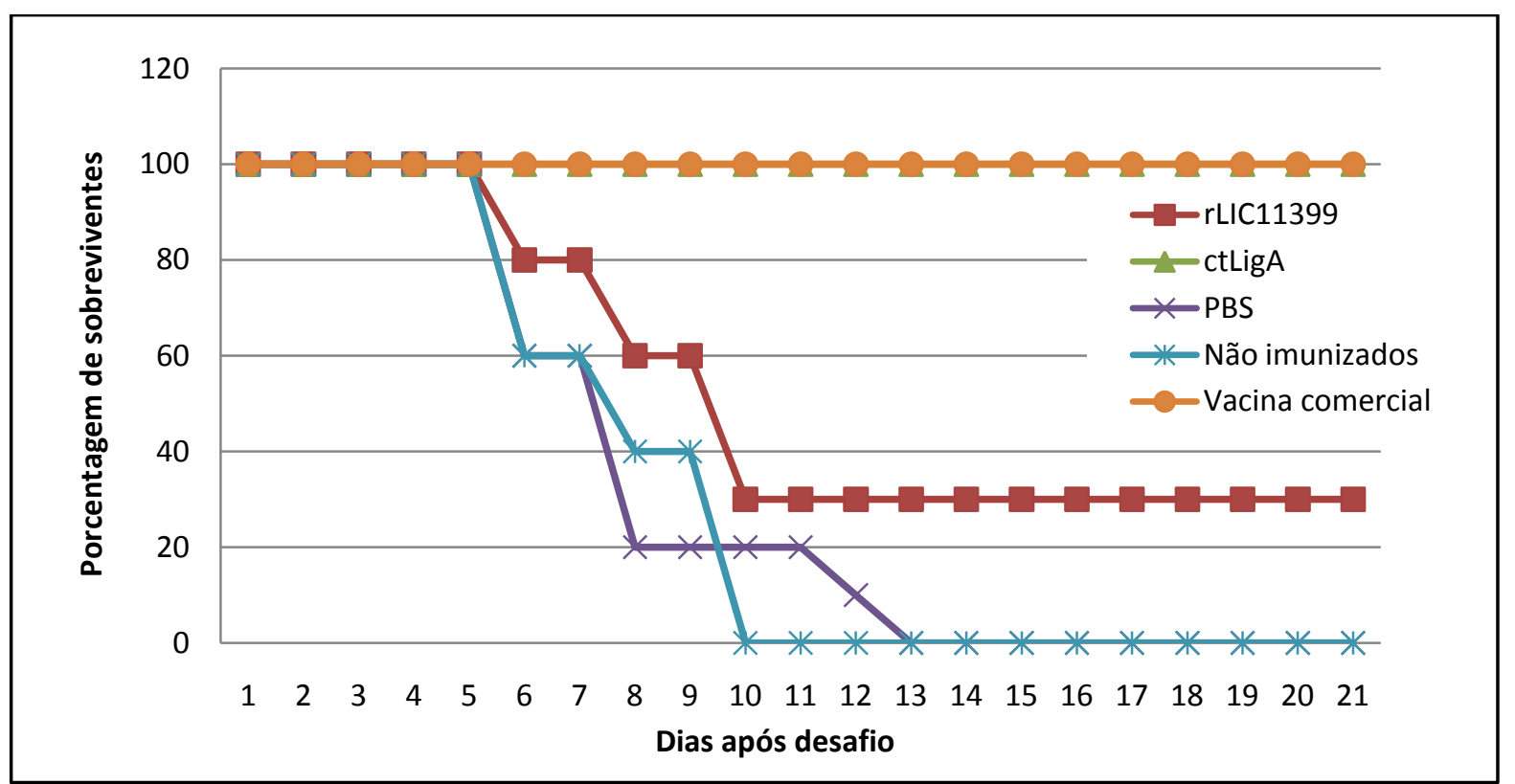

Figura 39 - Análise da porcentagem de sobrevivência dos grupos de animais vacinados e desafiados. Os animais imunizados com rLIC11399, ctLigA, PBS, vacina comercial ou não imunizados foram desafiados com a cepa $L$. interrogas sorovar Copenhageni virulento e observados por 21 dias.

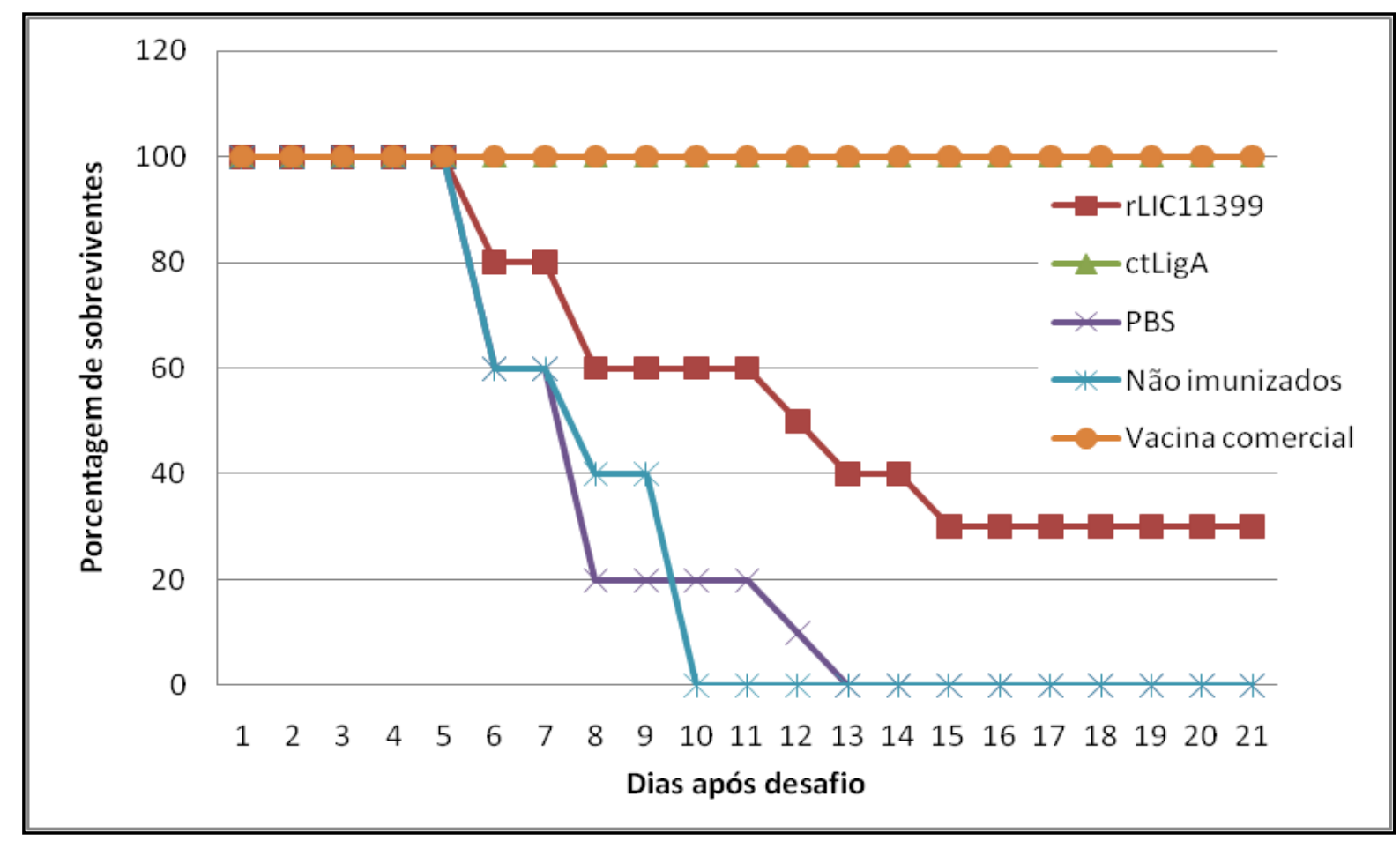


Tabela 08 - Avaliação do desafio animal quanto ao número de animais sobreviventes e a presença de leptospiras nos rins dos animais vacinados (portadores).

\begin{tabular}{cccc}
\hline $\begin{array}{c}\text { Grupos } \\
\text { vacinados }\end{array}$ & $\begin{array}{c}\text { Porcentagem de } \\
\text { sobrevivência }\end{array}$ & Vivos/total & $\begin{array}{c}\text { Portadores/Total de } \\
\text { sobreviventes }\end{array}$ \\
\hline rLIC11399 & $30 \%$ & $6 / 20$ & $2 / 6$ \\
ctLigA & $100 \%$ & $20 / 20$ & $20 / 20$ \\
PBS & --- & $0 / 10$ & --- \\
Não imunizado & --- & $0 / 20$ & --- \\
Vacina comercial & $100 \%$ & $20 / 20$ & $0 / 20$ \\
\hline
\end{tabular}




\section{DISCUSSÃO}

A notificação de ocorrências de leptospirose no Brasil ainda é compulsória e, a média referente à notificação entre 1997 e 2010 foi de aproximadamente 3.365 casos por ano, com taxa de mortalidade de aproximadamente $10 \%$ (155). O principal fator de risco para o óbito é o desenvolvimento de quadros hemorrágicos, principalmente a SPHL $(45,46)$. Neste sentido, urge o desenvolvimento de uma vacina profilática ou melhores tratamentos contra esta zoonose. Estão disponíveis atualmente no mercado vacinas para uso veterinário, obtidas a partir de preparação de leptospiras atenuadas ou inativadas por formaldeído ou calor, entretanto, essas formulações produzem apenas uma resposta imune de curta duração, não conferem proteção contra sorovares não contidos na preparação e podem causar reações adversas.

O seqüenciamento do genoma de 6 Leptospira, aliado ao desenvolvimento de ferramentas de bioinformática revolucionou o campo da vacinologia. Os constantes estudos no campo da biologia molecular, bioinformática e tecnologia de seqüenciamento propiciam melhorias e atualizações das inúmeras ferramentas e algoritmos para análises in silico. As análises de proteínas in silico a partir do genoma de um organismo são indicativas da provável função biológica, localização ou estrutura conformacional destas proteínas. Entretanto, apesar dos avanços nesse campo, a determinação absoluta da função ou localização de proteínas só é possível após a verificação in vivo. Assim sendo, visando contribuir de forma efetiva no melhor entendimento, diagnóstico e combate à disseminação da leptospirose, propusemos investigar e caracterizar 12 antígenos de L. interrogans sorovar Copenhageni (lic10881, lic20087, lic11211, lic10544, lic10291, lic13435, lic11399, lic10642, lic10359, lic12558, lic 10995 e lic 10468), cujas funções ainda não estão caracterizadas, para o desenvolvimento de uma possível vacina. No entanto, a versão do programa disponível no momento da seleção dos candidatos vacinais deste projeto (PSORTb v2.0.4) predizia que os 12 antígenos selecionados eram de membrana externa ou secretada pela bactéria L. interrogans sorovar Copenhageni. Porém, a atual versão deste mesmo programa (PSORTb v3.0.2) prediz que o gene lic10881 é codificante para uma proteína de membrana interna e o gene lic10642 é codificante para uma proteína citoplasmática, contrariando as predições realizadas inicialmente.

Proteínas cuja localização é intra-celular ou periplasmática ou de membrana interna da célula não são bons antígenos para o desenvolvimento de uma vacina, uma vez que não são 
apresentados ao sistema imune do hospedeiro. No entanto, diversas proteínas intracelulares participam de diversos processos regulatórios essenciais para a manutenção do patógeno, tais como metabolismo celular, geração de energia (ATP) (96), captação de nutrientes (156), sistema SOS $(96,157)$ entre outros. Portanto, apesar da ferramenta PSORTb v2.0.4 predizer que a sublocalização das proteínas LIC10881 e LIC10642 não serem de membrana externa ou secretada, a caracterização dessas proteínas pode contribuir para um melhor entendimento da fisiologia do patógeno. Além disso, a confirmação da verdadeira sublocalização celular de todas as proteínas selecionadas só poderá ser realizada após análises in vivo.

Além dos 12 antígenos selecionados para este projeto, o gene codificante para a região carboxi-terminal da proteína LigA e a região carboxi-terminal da proteína LytM de Staphylococcus aureus também foram selecionados para estudo. As proteínas da família Lig são expressas apenas no hospedeiro infectado e são restritos a espécies patogênicas (158). A expressão da proteína LigA está correlacionada com a virulência bacteriana e sua porção carboxi-terminal confere imunoproteção em hamsters desafiados com leptospiras (136), por este motivo optamos por clonar expressar e purificar a região carboxi-terminal dessa proteína a fim de utilizarmos como controle em nossos experimentos.

O gene lic11399 apresenta um domínio semelhante aos fatores V e VIII da cascata de coagulação na porção amino-terminal e um domínio semelhante ao de metalopeptidase da família M23 na porção carboxi-terminal. A família M23 compreende metaloproteases dependente de zinco e, a proteína LytM de Staphylococcus aureus, bastante caracterizada, é uma metaloprotease com atividade elastinolítica e domínio catalítico similar ao de LIC11399. Por este motivo, optamos por clonar, expressar e purificar a porção carboxi-terminal da proteína LIC11399 (ctLIC11399) e da proteína LytM (ctLytM) para utilizarmos como um controle em nossos experimentos.

Todos os genes selecionados foram clonados, porém, somente os antígenos rLIC13435, rLIC11399 a porção carboxi-terminal das proteínas LIC11399 (ctLIC11399), LigA (ctLigA) e LytM (ctLytM) foram possíveis de expressar e purificar. As proteínas recombinantes foram expressas em fusão com uma seqüência de seis resíduos de histidina em bactérias E. coli BL21 (SI) ou E. coli BL21(DE3) Star plysS. As proteínas recombinantes rLIC13435, ctLytM foram expressas na forma solúvel enquanto que rLIC11399, ctLIC11399 e ctLigA foram expressos em maiores quantidades na forma insolúvel, em corpúsculo de inclusão. As proteínas insolúveis foram solubilizadas pelo processo diluição para então serem purificadas. As proteínas foram purificadas através de cromatografia de afinidade a metais bivalentes e todas tiveram um bom rendimento final de $10 \mathrm{mg}$ a $35 \mathrm{mg}$ por litro de cultura. As 
proteínas purificadas tiveram a sua estrutura secundária avaliada por dicroísmo circular e os espectros obtidos indicam que todas as proteínas recombinantes apresentam uma estrutura regular. Camundongos foram imunizados intraperitonealmente para obtenção de soros hiperimunes e, os títulos dos anticorpos obtidos indicam que as proteínas são imunogênicas.

As proteínas recombinantes rLIC13435 e rLIC11399 foram avaliadas quanto à capacidade de interagir com componentes de matriz extracelular (MEC). Ambas as proteínas não apresentaram interação com os componentes testados.

As análises in silico das proteínas LIC13435, LIC11399 revelaram que essas proteínas estão presentes nos genomas de leptospiras patogênicas seqüenciados até agora e ausente nos genomas de leptospiras de vida livre. A conservação do gene lic13435 foi avaliada por PCR que confirmou a presença de genes ortólogos nos genomas de leptospiras patogênicas testados e ausente no genoma de leptospira saprofítica. As análises por RT-PCR também revelaram que além dos genes ortólogos estarem presentes nos genomas de bactérias patogênicas, o mesmo está sendo transcrito. Entretanto, a detecção por western-blot dessa proteína foi bastante variada. A inconstância na detecção da proteína nativa em extratos de leptospiras pode ser atribuída aos mecanismos que modulam o perfil de expressão protéica das bactérias de acordo com as condições ambientais em que estão submetidas (159). Ao longo do ciclo de transmissão da bactéria, que compreende desde órgãos de animais selvagens ou humanos, até vida livre no solo ou na água, as leptospiras são sujeitas a condições ambientais amplamente distintas e variáveis (2). Para se adaptarem a condições nutricionais, sinalizadoras, quimiotáticas e de virulência tão divergentes, as leptospiras necessitam de uma regulação de expressão do conjunto de genes expressos em cada uma dessas condições. Embora se saiba que as leptospiras se adaptem e sobrevivam em muitos ambientes diferentes, pouco é sabido a respeito da natureza molecular dessas adaptações. Assim sendo, é possível que a expressão da proteína nativa LIC13435 pela bactéria seja modulada pelas condições de cultivo e por esta razão a sua detecção por western blot seja variada. Assim sendo, não foi possível determinar a expressão da proteína nativa LIC13435 por Leptospira patogênicas. O seqüenciamento da proteína recombinante pelo método de Edman confirmou a purificação da proteína correta. A pesquisa de anticorpos anti rLIC13435 em soros de pacientes humanos e hamsters infectados não evidenciou anticorpos dirigidos contra a proteína recombinante. Os ensaios de imunização e desafio homólogo contra leptospira virulenta revelaram que esta proteína é ineficaz como candidato vacinal, por estes motivos os estudos com essa proteína foram finalizados. 
Com relação à proteína LIC11399, a conservação do gene e expressão da proteína foram avaliadas através da técnica de western blot, que detectou a expressão da proteína nativa somente em extratos de espécies de leptospiras patogênicas. Além da expressão da proteína nativa em variados extratos de leptospiras, verificamos também reatividade cruzada entre os soros gerados contra as proteína rLIC11399 e ctLIC11399, reforçando a qualidade das proteínas e soros gerados. A pesquisa de anticorpos anti rLIC11399 em soros de hamsters e pacientes infectados por leptospirose detectou a presença de anticorpos do tipo $\operatorname{IgG}$ (fase imune) dirigidos contra a proteína recombinante, indicando que a proteína nativa é apresentada ao sistema imune do hospedeiro durante a infecção. No entanto, não foi possível evidenciar anticorpos do tipo IgM (fase aguda), em soros de pacientes de primeira semana de infecção. Também foi possível detectar a presença da proteína nativa no sobrenadante de culturas de leptospiras, indicando que a mesma é secretada pela bactéria.

Para avaliar a hipótese de as proteínas rLIC11399 e ctLIC11399 possuírem atividade elastinolítica, clonamos expressamos e purificamos a região carboxi-terminal de LytM (ctLytM) de Staphylococcus aureus para utilizarmos como controle em nossos experimentos. A proteína LytM é uma metaloprotease com atividade elastinolítica bastante caracterizada, no entanto, a proteína purificada em nosso laboratório não apresentou a atividade esperada nas condições testadas. Os resultados indicam que as proteínas rLIC11399 e ctLIC11399 possuem atividade proteolítica sobre o substrato comercial Elastina-Congo Red. Entretanto, apesar da atividade ter sido inibida na presença de quelante, foi preciso aplicar uma quantidade grande de proteína para verificarmos a presença da atividade elastinolítica. A necessidade de utilizarmos uma quantidade grande de proteínas pode ser atribuída a pouca quantidade de proteínas ativas. Apesar do espectro obtido por dicroísmo circular indicar que a proteína está estruturada, há a possibilidade de apenas poucas proteínas estarem com o sítio catalítico corretamente estruturado após o processo de refolding ao qual a proteína é submetida antes da purificação. Além disso, como as proteínas foram geradas em sistema heterólogo, é possível que contaminantes de Escherichia coli tenham sido co-purificadas e estes estarem reagindo com a elastina. Por estes motivos, buscamos avaliar a atividade proteolítica por zimografia para eliminar a possibilidade de contaminantes estarem reagindo com o substrato elastina. No entanto, não foi verificado nenhuma atividade proteolítica por parte da proteína recombinante ctLIC11399 ou contaminantes. A zimografia é uma técnica que evidencia proteínas com atividades enzimáticas específicas, porém, exige bastante manipulação do material a ser avaliado. Assim sendo, é possível que a atividade proteolítica das poucas proteínas ativas presentes na amostra tenha se perdido. 
Em dois ensaios indepentendes, a imunização de hamsters com a proteína rLIC11399 na presença de hidróxido de alumínio como adjuvante conferiu proteção em 30\% dos animais desafiados com leptospira virulenta. Apesar de dois terços dos animais sobreviventes não terem apresentado leptospiras no cultivo do macerado dos rins dos mesmos, é necessário fazer mais análises, por exemplo, um PCR para detectar a presença de DNA leptospiral para ter certeza de que estes animais não portavam leptospiras. A porção carboxi-terminal de LigA foi incorporado ao experimento como um controle positivo de proteína recombinante que apresenta atividade protetora $(136,160)$. Como esperado, a imunização com a porção carboxi-terminal de LigA conferiu $100 \%$ de proteção porém, conforme os resultados descritos na literatura, a proteção não foi esterilizante pois os animais continuavam sendo portadores de leptospiras nos rins.

Embora o potencial hemorrágico da leptospirose ter sido descrita em 1886 por Weil e, diversos estudos tenham se focado para esta forma da doença $(45,48-54)$, o mecanismo de sua fisiopatologia ainda não foi completamente elucidado. Como mencionado na introdução, estudos propõem a ação de toxinas e processos auto-imunes como responsáveis pela progressão da doença para a SPHL, a forma mais letal da leptospirose. A baixa quantidade de bactérias recuperadas do tecido pulmonar sugere uma possível toxina bacteriana circulante, produzida de algum lugar distante (109) e, a toxina responsável ainda não foi identificada.

Neste trabalho, levantamos a hipótese de que a proteína nativa LIC11399 possa estar relacionada com a degradação de elastina e eventos hemorrágicos, pois, possui um domínio semelhante ao de metalopeptidase da família M23 caracterizada por degradar elastina. Também foi demonstrado que a proteína nativa LIC11399 é expressa por diversas espécies de leptospiras patogênicas, secretada para o meio de cultura e apresentada ao sistema imune do hospedeiro durante a infecção. Entretanto, nas condições experimentais testadas, as proteínas rLIC11399 e ctLIC11399 não apresentaram uma atividade elastinolítica robusta.

Baseando-se nos dados gerados por este trabalho, é possível afirmar que os resultados apresentados são de grande contribuição para a compreensão da biologia e patogenicidade das leptospiras. A idenditificação da proteína LIC11399 abre caminho para a investigação de uma possível protease envolvida nos processos hemorrágicos tão letais para essa importante zoonose. A compreensão dos processos hemorrágicos e / ou a identificação da possível toxina permitirá o desenvolvimento de melhores bases terapêuticas para o tratamento da doença e / ou prevenção da SPHL e, conseqüentemente, redução das altas taxas de mortes por leptospirose. 


\section{CONCLUSÕES}

1 - Foram selecionados 12 genes que codificam proteínas hipotéricas conservadas, preditas como sendo de superfície externa ou secretada por Leptospira interrogans sorovar Copenhageni.

2 - Somente as proteínas rLIC13545, rLIC11399, ctLIC11399, ctLigA e ctLytM foram possíveis de expressar e purificar.

4 - Todas as proteínas purificadas apresentaram integridade estrutural.

5 - As proteínas purificadas são bastante imunogênicas. Os títulos dos anticorpos foram superiores a 256.000 .

6 - Genes ortólogos de lic13435 estão presentes nos genomas das espécies patogênicas de Leptospira testados.

7 - Transcritos gênicos de LIC13435 foram detectados por RT-PCR, porém, a detecção da proteína nativa foi inconstante.

8 - Soros de hamster e pacientes com leptospirose não foram capazes de detectar a proteína rLIC13435.

9 - A proteína rLIC13435 é ineficaz como candidato vacinal.

10 - Genes ortólogos de lic11399 estão presentes nos genomas de Leptospira patogênicas e, a proteína nativa é expressa por diversas espécies patogênicas.

11 - Os soros de hamster e pacientes humanos infectados evidenciaram anticorpos do tipo IgG dirigido contra a proteína rLIC11399 porém, não foi possível evidenciar anticorpos do tipo IgM.

12 - As proteínas rLIC13435 e rLIC11399 não interagem com os componentes de matriz extracelular testados.

13 - A proteína nativa LIC11399 é secretada pela bactéria durante seu crescimento in vitro. 
14 - A imunização com rLIC11399 conferiu proteção em $30 \%$ dos animais em dois ensaios de imunização e desafio homólogo com L. interrogans sorovar Copenhageni.

15 - As proteínas rLIC11399 e ctLIC11399 apresentaram uma baixa atividade elastotinolíca nas condições testadas. 


\section{REFERÊNCIAS}

1. Seidman CE, Murphy PA. Leptospirosis. Johns Hopkins Med J. 1980 Aug;147(2):659.

2. Haake DA, Chao G, Zuerner RL, Barnett JK, Barnett D, Mazel M, et al. The leptospiral major outer membrane protein LipL32 is a lipoprotein expressed during mammalian infection. Infect Immun. 2000 Apr;68(4):2276-85.

3. Faine S. AB, Bolin C., Perolat P. Leptospira and Leptospirosis. 2nd ed: Published by MediSci, Melbourne, Vic. Australia.; 1999.

4. Nahori MA, Fournie-Amazouz E, Que-Gewirth NS, Balloy V, Chignard M, Raetz CR, et al. Differential TLR recognition of leptospiral lipid A and lipopolysaccharide in murine and human cells. J Immunol. 2005 Nov 1;175(9):6022-31.

5. Que-Gewirth NL, Ribeiro AA, Kalb SR, Cotter RJ, Bulach DM, Adler B, et al. A methylated phosphate group and four amide-linked acyl chains in leptospira interrogans lipid A. The membrane anchor of an unusual lipopolysaccharide that activates TLR2. J Biol Chem. 2004 Jun 11;279(24):25420-9.

6. Werts C, Tapping RI, Mathison JC, Chuang TH, Kravchenko V, Saint Girons I, et al. Leptospiral lipopolysaccharide activates cells through a TLR2-dependent mechanism. Nat Immunol. 2001 Apr;2(4):346-52.

7. Raetz CR, Ulevitch RJ, Wright SD, Sibley CH, Ding A, Nathan CF. Gram-negative endotoxin: an extraordinary lipid with profound effects on eukaryotic signal transduction. FASEB J. 1991 Sep;5(12):2652-60.

8. Goldstein SF, Charon NW. Motility of the spirochete Leptospira. Cell Motil Cytoskeleton. 1988;9(2):101-10.

9. Schmid GP. Epidemiology and clinical similarities of human spirochetal diseases. Rev Infect Dis. 1989 Sep-Oct;11 Suppl 6:S1460-9.

10. Charon NW, Goldstein SF. Genetics of motility and chemotaxis of a fascinating group of bacteria: the spirochetes. Annu Rev Genet. 2002;36:47-73.

11. Trueba G, Zapata S, Madrid K, Cullen P, Haake D. Cell aggregation: a mechanism of pathogenic Leptospira to survive in fresh water. Int Microbiol. 2004 Mar;7(1):35-40.

12. Ristow P, Bourhy P, Kerneis S, Schmitt C, Prevost MC, Lilenbaum W, et al. Biofilm formation by saprophytic and pathogenic leptospires. Microbiology. 2008 May;154(Pt 5):1309-17. 
13. Bharti AR, Nally JE, Ricaldi JN, Matthias MA, Diaz MM, Lovett MA, et al. Leptospirosis: a zoonotic disease of global importance. Lancet Infect Dis. 2003 Dec;3(12):757-71.

14. Chang SL, Buckingham M, Taylor MP. Studies on Leptospira icterohaemorrhagiae; survival in water and sewage; destruction in water by halogen compounds, synthetic detergents, and heat. J Infect Dis. 1948 May-Jun;82(3):256-66.

15. Bourhy P, Salaun L, Lajus A, Medigue C, Boursaux-Eude C, Picardeau M. A genomic island of the pathogen Leptospira interrogans serovar Lai can excise from its chromosome. Infect Immun. 2007 Feb;75(2):677-83.

16. Lo M, Bulach DM, Powell DR, Haake DA, Matsunaga J, Paustian ML, et al. Effects of temperature on gene expression patterns in Leptospira interrogans serovar Lai as assessed by whole-genome microarrays. Infect Immun. 2006 Oct;74(10):5848-59.

17. Yang HL, Jiang XC, Zhang XY, Li WJ, Hu BY, Zhao GP, et al. Thrombocytopenia in the experimental leptospirosis of guinea pig is not related to disseminated intravascular coagulation. BMC Infect Dis. 2006;6:19.

18. Paster BJ, Dewhirst FE, Weisburg WG, Tordoff LA, Fraser GJ, Hespell RB, et al. Phylogenetic analysis of the spirochetes. J Bacteriol. 1991 Oct;173(19):6101-9.

19. Dikken H, Kmety E, de Geus A, Adinarayanan N, Timmer VE. Two new leptospira serovars belonging to the Hebdomadis serogroup. Trop Geogr Med. 1978 Dec;30(4):537-42.

20. Levett PN. Leptospirosis. Clin Microbiol Rev. 2001 Apr;14(2):296-326.

21. Levett PN. Sequence-based typing of leptospira: epidemiology in the genomic era. PLoS Negl Trop Dis. 2007;1(2):e120.

22. Cerqueira GM, Picardeau M. A century of Leptospira strain typing. Infect Genet Evol. 2009 Sep;9(5):760-8.

23. Brenner DJ, Kaufmann AF, Sulzer KR, Steigerwalt AG, Rogers FC, Weyant RS. Further determination of DNA relatedness between serogroups and serovars in the family Leptospiraceae with a proposal for Leptospira alexanderi sp. nov. and four new Leptospira genomospecies. Int J Syst Bacteriol. 1999 Apr;49 Pt 2:839-58.

24. Ko AI, Galvao Reis M, Ribeiro Dourado CM, Johnson WD, Jr., Riley LW. Urban epidemic of severe leptospirosis in Brazil. Salvador Leptospirosis Study Group. Lancet. 1999 Sep 4;354(9181):820-5.

25. Pereira MM, Matsuo MG, Bauab AR, Vasconcelos SA, Moraes ZM, Baranton G, et al. A clonal subpopulation of Leptospira interrogans sensu stricto is the major cause of leptospirosis outbreaks in Brazil. J Clin Microbiol. 2000 Jan;38(1):450-2. 
26. Romero EC, Bernardo CC, Yasuda PH. Human leptospirosis: a twenty-nine-year serological study in Sao Paulo, Brazil. Rev Inst Med Trop Sao Paulo. 2003 SepOct;45(5):245-8.

27. Schroder NW, Eckert J, Stubs G, Schumann RR. Immune responses induced by spirochetal outer membrane lipoproteins and glycolipids. Immunobiology. 2008;213(34):329-40.

28. Levett PN. Leptospirosis: re-emerging or re-discovered disease? J Med Microbiol. 1999 May;48(5):417-8.

29. Vinetz JM. Leptospirosis. Curr Opin Infect Dis. 2001 Oct;14(5):527-38.

30. Katz AR, Ansdell VE, Effler PV, Middleton CR, Sasaki DM. Leptospirosis in Hawaii, 1974-1998: epidemiologic analysis of 353 laboratory-confirmed cases. Am J Trop Med Hyg. 2002 Jan;66(1):61-70.

31. Bharadwaj R. Leptospirosis--a reemerging disease? Indian J Med Res. 2004 Sep;120(3):136-8.

32. Plank R, Dean D. Overview of the epidemiology, microbiology, and pathogenesis of Leptospira spp. in humans. Microbes Infect. 2000 Aug;2(10):1265-76.

33. Ko AI, Goarant C, Picardeau M. Leptospira: the dawn of the molecular genetics era for an emerging zoonotic pathogen. Nat Rev Microbiol. 2009 Oct;7(10):736-47.

34. Waitkins SA. Leptospirosis as an occupational disease. $\mathrm{Br}$ J Ind Med. 1986 Nov;43(11):721-5.

35. Flannery B, Costa D, Carvalho FP, Guerreiro H, Matsunaga J, Da Silva ED, et al. Evaluation of recombinant Leptospira antigen-based enzyme-linked immunosorbent assays for the serodiagnosis of leptospirosis. J Clin Microbiol. 2001 Sep;39(9):3303-10.

36. Update: outbreak of acute febrile illness among athletes participating in EcoChallenge-Sabah 2000--Borneo, Malaysia, 2000. MMWR Morb Mortal Wkly Rep. 2001 Jan $19 ; 50(2): 21-4$.

37. Update: leptospirosis and unexplained acute febrile illness among athletes participating in triathlons--Illinois and Wisconsin, 1998. MMWR Morb Mortal Wkly Rep. 1998 Aug 21;47(32):673-6.

38. Dolhnikoff M, Mauad T, Bethlem EP, Carvalho CR. Pathology and pathophysiology of pulmonary manifestations in leptospirosis. Braz J Infect Dis. 2007 Feb;11(1):142-8.

39. WHO. Leptospirosis worldwid. Wkly Epidemiol Rec. 1999;Jul 23(74(29):237-42). 
40. Park SK, Lee SH, Rhee YK, Kang SK, Kim KJ, Kim MC, et al. Leptospirosis in Chonbuk Province of Korea in 1987: a study of 93 patients. Am J Trop Med Hyg. 1989 Sep;41(3):345-51.

41. O'Neil KM, Rickman LS, Lazarus AA. Pulmonary manifestations of leptospirosis. Rev Infect Dis. 1991 Jul-Aug;13(4):705-9.

42. Andreescu N, Badulescu A, Gavrila S, Popa AC. Leptospirotic etiology in pulmonary and upper respiratory tract pathology. Roum Arch Microbiol Immunol. 1999 Jul-Dec;58(34):273-9.

43. Gouveia EL, Metcalfe J, de Carvalho AL, Aires TS, Villasboas-Bisneto JC, Queirroz A, et al. Leptospirosis-associated severe pulmonary hemorrhagic syndrome, Salvador, Brazil. Emerg Infect Dis. 2008 Mar;14(3):505-8.

44. McBride AJ, Athanazio DA, Reis MG, Ko AI. Leptospirosis. Curr Opin Infect Dis. 2005 Oct;18(5):376-86.

45. Marotto PC, Nascimento CM, Eluf-Neto J, Marotto MS, Andrade L, Sztajnbok J, et al. Acute lung injury in leptospirosis: clinical and laboratory features, outcome, and factors associated with mortality. Clin Infect Dis. 1999 Dec;29(6):1561-3.

46. Marotto PC, Marotto MS, Santos DL, Souza TN, Seguro AC. Outcome of leptospirosis in children. Am J Trop Med Hyg. 1997 Mar;56(3):307-10.

47. Sejvar J, Bancroft E, Winthrop K, Bettinger J, Bajani M, Bragg S, et al. Leptospirosis in "Eco-Challenge" athletes, Malaysian Borneo, 2000. Emerg Infect Dis. 2003 Jun;9(6):702-7. 48. Nally JE, Chantranuwat C, Wu XY, Fishbein MC, Pereira MM, Da Silva JJ, et al. Alveolar septal deposition of immunoglobulin and complement parallels pulmonary hemorrhage in a guinea pig model of severe pulmonary leptospirosis. Am J Pathol. 2004 Mar;164(3):1115-27.

49. Nicodemo AC, Duarte MI, Alves VA, Takakura CF, Santos RT, Nicodemo EL. Lung lesions in human leptospirosis: microscopic, immunohistochemical, and ultrastructural features related to thrombocytopenia. Am J Trop Med Hyg. 1997 Feb;56(2):181-7.

50. Theilen HJ, Luck C, Hanisch U, Ragaller M. Fatal intracerebral hemorrhage due to leptospirosis. Infection. 2002 Apr;30(2):109-12.

51. Chierakul W, Tientadakul P, Suputtamongkol Y, Wuthiekanun V, Phimda K, Limpaiboon R, et al. Activation of the coagulation cascade in patients with leptospirosis. Clin Infect Dis. 2008 Jan 15;46(2):254-60. 
52. Zaki SR, Shieh WJ. Leptospirosis associated with outbreak of acute febrile illness and pulmonary haemorrhage, Nicaragua, 1995. The Epidemic Working Group at Ministry of Health in Nicaragua. Lancet. 1996 Feb 24;347(9000):535-6.

53. Wagenaar JF, de Vries PJ, Hartskeerl RA. Leptospirosis with pulmonary hemorrhage, caused by a new strain of serovar Lai: Langkawi. J Travel Med. 2004 Nov-Dec;11(6):379-81.

54. Yersin C, Bovet P, Merien F, Clement J, Laille M, Van Ranst M, et al. Pulmonary haemorrhage as a predominant cause of death in leptospirosis in Seychelles. Trans R Soc Trop Med Hyg. 2000 Jan-Feb;94(1):71-6.

55. Farr RW. Leptospirosis. Clin Infect Dis. $1995 \mathrm{Jul} ; 21(1): 1-6$; quiz 7-8.

56. Edwards GA. Anicteric Leptospirosis. Med Sci. 1963 Oct;14:56-62.

57. Turner LH. Leptospirosis. I. Trans R Soc Trop Med Hyg. 1967;61(6):842-55.

58. Alani FS, Mahoney MP, Ormerod LP, Wright PA, Garrues M. Leptospirosis presenting as atypical pneumonia, respiratory failure and pyogenic meningitis. J Infect. 1993 Nov;27(3):281-3.

59. Spichler AS, Vilaca PJ, Athanazio DA, Albuquerque JO, Buzzar M, Castro B, et al. Predictors of lethality in severe leptospirosis in urban Brazil. Am J Trop Med Hyg. 2008 Dec;79(6):911-4.

60. Thongboonkerd V. Proteomics in leptospirosis research: towards molecular diagnostics and vaccine development. Expert Rev Mol Diagn. 2008 Jan;8(1):53-61.

61. Thiermann AB. Isolation of leptospires in diagnosis of leptospirosis. Mod Vet Pract. 1984 Oct;65(10):758-9.

62. WHO. Human leptospirosis: guidance for diagnosis, surveillance and control. Malta: World Health Organization. 2003.

63. Bajani MD, Ashford DA, Bragg SL, Woods CW, Aye T, Spiegel RA, et al. Evaluation of four commercially available rapid serologic tests for diagnosis of leptospirosis. J Clin Microbiol. 2003 Feb;41(2):803-9.

64. Cox CD. Standardization and stabilization of an extract from Leptospira biflexa and its use in the hemolytic test for leptospirosis. J Infect Dis. 1957 Sep-Oct;101(2):203-9.

65. Faine. ed. Guidelines for the control of leptospirosis. Geneva, Switzerland: World Health Organization, 1982; WHO offset publication no 67. 1982.

66. Brandao AP, Camargo ED, da Silva ED, Silva MV, Abrao RV. Macroscopic agglutination test for rapid diagnosis of human leptospirosis. J Clin Microbiol. 1998 Nov;36(11):3138-42. 
67. Levett PN, Whittington CU. Evaluation of the indirect hemagglutination assay for diagnosis of acute leptospirosis. J Clin Microbiol. 1998 Jan;36(1):11-4.

68. Sulzer CR, Glosser JW, Rogers F, Jones WL, Frix M. Evaluation of an indirect hemagglutination test for the diagnosis of human leptospirosis. J Clin Microbiol. 1975 Sep;2(3):218-21.

69. Torten M, Shenberg E, Van der Hoeden J. The use of immunofluorescence in the diagnosis of human leptospirosis by a genus-specific antigen. J Infect Dis. 1966 Dec;116(5):537-43.

70. Arimitsu Y, Kmety E, Ananyina Y, Baranton G, Ferguson IR, Smythe L, et al. Evaluation of the one-point microcapsule agglutination test for diagnosis of leptospirosis. Bull World Health Organ. 1994;72(3):395-9.

71. Adler B, Faine S, Gordon LM. The enzyme-linked immunosorbent assay (ELISA) as a serological test for detecting antibodies against Leptospira interrogans serovar hardjo in sheep. Aust Vet J. 1981 Sep;57(9):414-7.

72. Terpstra WJ, Ligthart GS, Schoone GJ. Serodiagnosis of human leptospirosis by enzyme-linked-immunosorrbent-assay (ELISA). Zentralbl Bakteriol A. 1980 Aug;247(3):4005.

73. Millar BD, Chappel RJ, Adler B. Detection of leptospires in biological fluids using DNA hybridisation. Vet Microbiol. 1987 Oct;15(1-2):71-8.

74. Terpstra WJ, Schoone GJ, Ligthart GS, ter Schegget J. Detection of Leptospira interrogans in clinical specimens by in situ hybridization using biotin-labelled DNA probes. $\mathrm{J}$ Gen Microbiol. 1987 Apr;133(4):911-4.

75. Woodward MJ, Sullivan GJ, Palmer NM, Woolley JC, Redstone JS. Development of a PCR test specific for Leptospira hardjo genotype bovis. Vet Rec. 1991 Mar 23;128(12):282-3.

76. Murgia R, Riquelme N, Baranton G, Cinco M. Oligonucleotides specific for pathogenic and saprophytic leptospira occurring in water. FEMS Microbiol Lett. 1997 Mar $1 ; 148(1): 27-34$.

77. Parma AE, Seijo A, Lucchesi PM, Deodato B, Sanz ME. Differentiation of pathogenic and non-pathogenic leptospires by means of the polymerase chain reaction. Rev Inst Med Trop Sao Paulo. 1997 Jul-Aug;39(4):203-7.

78. Woo TH, Patel BK, Smythe LD, Symonds ML, Norris MA, Dohnt MF. Comparison of two PCR methods for rapid identification of Leptospira genospecies interrogans. FEMS Microbiol Lett. 1997 Oct 15;155(2):169-77. 
79. Heinemann MB, Garcia JF, Nunes CM, Gregori F, Higa ZM, Vasconcellos SA, et al. Detection and differentiation of Leptospira spp. serovars in bovine semen by polymerase chain reaction and restriction fragment length polymorphism. Vet Microbiol. 2000 May $11 ; 73(4): 261-7$.

80. Sehgal SC, Sugunan AP, Murhekar MV, Sharma S, Vijayachari P. Randomized controlled trial of doxycycline prophylaxis against leptospirosis in an endemic area. Int $\mathbf{J}$ Antimicrob Agents. 2000 Feb;13(4):249-55.

81. Bolin CA, Zuerner RL, Trueba G. Effect of vaccination with a pentavalent leptospiral vaccine containing Leptospira interrogans serovar hardjo type hardjo-bovis on type hardjobovis infection of cattle. Am J Vet Res. 1989 Dec;50(12):2004-8.

82. Martinez Sanchez R, Obregon Fuentes AM, Perez Sierra A, Baly Gil A, Diaz Gonzalez M, Baro Suarez M, et al. [The reactogenicity and immunogenicity of the first Cuban vaccine against human leptospirosis]. Rev Cubana Med Trop. 1998;50(2):159-66.

83. Martinez Sanchez R, Perez Sierra A, Baro Suarez M, Alvarez AM, Menendez Hernandez J, Diaz Gonzalez M, et al. [Evaluation of the effectiveness of a new vaccine against human leptospirosis in groups at risk]. Rev Panam Salud Publica. 2000 Dec;8(6):38592.

84. Ikoev VN, Gorbunov MA, Vachaev BF, Iagovkin EA, Kondratenko VF, Anan'ina Iu $\mathrm{V}$, et al. [The evaluation of the reactogenicity and immunogenic activity of a new concentrated inactivated leptospirosis vaccine]. Zh Mikrobiol Epidemiol Immunobiol. 1999 Jul-Aug(4):39-43.

85. Chen T. [Development and present status of a leptospiral vaccine and the technology of vaccine production in China]. Nippon Saikingaku Zasshi. 1985 Jul;40(4):755-62.

86. Haake DA, Mazel MK, McCoy AM, Milward F, Chao G, Matsunaga J, et al. Leptospiral outer membrane proteins OmpL1 and LipL41 exhibit synergistic immunoprotection. Infect Immun. 1999 Dec;67(12):6572-82.

87. Matsunaga J, Barocchi MA, Croda J, Young TA, Sanchez Y, Siqueira I, et al. Pathogenic Leptospira species express surface-exposed proteins belonging to the bacterial immunoglobulin superfamily. Mol Microbiol. 2003 Aug;49(4):929-45.

88. Cullen PA, Haake DA, Bulach DM, Zuerner RL, Adler B. LipL21 is a novel surfaceexposed lipoprotein of pathogenic Leptospira species. Infect Immun. 2003 May;71(5):241421.

89. Hauk P, Macedo F, Romero EC, Vasconcellos SA, de Morais ZM, Barbosa AS, et al. In LipL32, the major leptospiral lipoprotein, the $\mathrm{C}$ terminus is the primary immunogenic 
domain and mediates interaction with collagen IV and plasma fibronectin. Infect Immun. 2008 Jun;76(6):2642-50.

90. Barbosa AS, Monaris D, Silva LB, Morais ZM, Vasconcellos SA, Cianciarullo AM, et al. Functional characterization of LcpA, a surface-exposed protein of Leptospira spp. that binds the human complement regulator C4BP. Infect Immun. 2010 Jul;78(7):3207-16.

91. Ristow P, Bourhy P, da Cruz McBride FW, Figueira CP, Huerre M, Ave P, et al. The OmpA-like protein Loa22 is essential for leptospiral virulence. PLoS Pathog. 2007 Jul;3(7):e97.

92. Gamberini M, Gomez RM, Atzingen MV, Martins EA, Vasconcellos SA, Romero EC, et al. Whole-genome analysis of Leptospira interrogans to identify potential vaccine candidates against leptospirosis. FEMS Microbiol Lett. 2005 Mar 15;244(2):305-13.

93. Amato MB, Barbas CS, Medeiros DM, Magaldi RB, Schettino GP, Lorenzi-Filho G, et al. Effect of a protective-ventilation strategy on mortality in the acute respiratory distress syndrome. N Engl J Med. 1998 Feb 5;338(6):347-54.

94. Andrade L, Cleto S, Seguro AC. Door-to-dialysis time and daily hemodialysis in patients with leptospirosis: impact on mortality. Clin J Am Soc Nephrol. 2007 Jul;2(4):73944.

95. Ren SX, Fu G, Jiang XG, Zeng R, Miao YG, Xu H, et al. Unique physiological and pathogenic features of Leptospira interrogans revealed by whole-genome sequencing. Nature. 2003 Apr 24;422(6934):888-93.

96. Nascimento AL, Ko AI, Martins EA, Monteiro-Vitorello CB, Ho PL, Haake DA, et al. Comparative genomics of two Leptospira interrogans serovars reveals novel insights into physiology and pathogenesis. J Bacteriol. 2004 Apr;186(7):2164-72.

97. Nascimento AL, Verjovski-Almeida S, Van Sluys MA, Monteiro-Vitorello CB, Camargo LE, Digiampietri LA, et al. Genome features of Leptospira interrogans serovar Copenhageni. Braz J Med Biol Res. 2004 Apr;37(4):459-77.

98. Bulach DM, Zuerner RL, Wilson P, Seemann T, McGrath A, Cullen PA, et al. Genome reduction in Leptospira borgpetersenii reflects limited transmission potential. Proc Natl Acad Sci U S A. 2006 Sep 26;103(39):14560-5.

99. Picardeau M, Bulach DM, Bouchier C, Zuerner RL, Zidane N, Wilson PJ, et al. Genome sequence of the saprophyte Leptospira biflexa provides insights into the evolution of Leptospira and the pathogenesis of leptospirosis. PLoS One. 2008;3(2):e1607.

100. Xue F, Yan J, Picardeau M. Evolution and pathogenesis of Leptospira spp.: lessons learned from the genomes. Microbes Infect. 2009 Mar;11(3):328-33. 
101. Barbosa AS, Abreu PA, Neves FO, Atzingen MV, Watanabe MM, Vieira ML, et al. A newly identified leptospiral adhesin mediates attachment to laminin. Infect Immun. 2006 Nov;74(11):6356-64.

102. Choy HA, Kelley MM, Chen TL, Moller AK, Matsunaga J, Haake DA. Physiological osmotic induction of Leptospira interrogans adhesion: LigA and LigB bind extracellular matrix proteins and fibrinogen. Infect Immun. 2007 May;75(5):2441-50.

103. Lin YP, Lee DW, McDonough SP, Nicholson LK, Sharma Y, Chang YF. Repeated domains of leptospira immunoglobulin-like proteins interact with elastin and tropoelastin. $\mathbf{J}$ Biol Chem. 2009 Jul 17;284(29):19380-91.

104. Breiner DD, Fahey M, Salvador R, Novakova J, Coburn J. Leptospira interrogans binds to human cell surface receptors including proteoglycans. Infect Immun. 2009 Dec;77(12):5528-36.

105. Thomas DD, Higbie LM. In vitro association of leptospires with host cells. Infect Immun. 1990 Mar;58(3):581-5.

106. Liu Y, Zheng W, Li L, Mao Y, Yan J. Pathogenesis of leptospirosis: interaction of Leptospira interrogans with in vitro cultured mammalian cells. Med Microbiol Immunol. 2007 Dec;196(4):233-9.

107. Barocchi MA, Ko AI, Reis MG, McDonald KL, Riley LW. Rapid translocation of polarized MDCK cell monolayers by Leptospira interrogans, an invasive but nonintracellular pathogen. Infect Immun. 2002 Dec;70(12):6926-32.

108. Li S, Ojcius DM, Liao S, Li L, Xue F, Dong H, et al. Replication or death: distinct fates of pathogenic Leptospira strain Lai within macrophages of human or mouse origin. Innate Immun. 2010;16(2):80-92.

109. Miller NG, Allen JE, Wilson RB. The pathogenesis of hemorrhage in the lung of the hamster during acute leptospirosis. Med Microbiol Immunol. 1974;160(4):269-78.

110. Yang GG, Hsu YH. Nitric oxide production and immunoglobulin deposition in leptospiral hemorrhagic respiratory failure. J Formos Med Assoc. 2005 Oct;104(10):759-63.

111. Croda J, Neto AN, Brasil RA, Pagliari C, Nicodemo AC, Duarte MI. Leptospirosis pulmonary haemorrhage syndrome is associated with linear deposition of immunoglobulin and complement on the alveolar surface. Clin Microbiol Infect. 2010 Jun;16(6):593-9.

112. Fleischmann RD, Adams MD, White O, Clayton RA, Kirkness EF, Kerlavage AR, et al. Whole-genome random sequencing and assembly of Haemophilus influenzae Rd. Science. $1995 \mathrm{Jul}$ 28;269(5223):496-512. 
113. Adu-Bobie J, Capecchi B, Serruto D, Rappuoli R, Pizza M. Two years into reverse vaccinology. Vaccine. 2003 Jan 30;21(7-8):605-10.

114. Koizumi N, Watanabe H. Leptospirosis vaccines: past, present, and future. J Postgrad Med. 2005 Jul-Sep;51(3):210-4.

115. Koizumi N, Watanabe H. Identification of a novel antigen of pathogenic Leptospira spp. that reacted with convalescent mice sera. J Med Microbiol. 2003 Jul;52(Pt 7):585-9.

116. Medini D, Serruto D, Parkhill J, Relman DA, Donati C, Moxon R, et al. Microbiology in the post-genomic era. Nat Rev Microbiol. 2008 Jun;6(6):419-30.

117. Rappuoli R. Reverse vaccinology, a genome-based approach to vaccine development. Vaccine. 2001 Mar 21;19(17-19):2688-91.

118. Rappuoli R. Reverse vaccinology. Curr Opin Microbiol. 2000 Oct;3(5):445-50.

119. Pizza M, Scarlato V, Masignani V, Giuliani MM, Arico B, Comanducci M, et al. Identification of vaccine candidates against serogroup B meningococcus by whole-genome sequencing. Science. 2000 Mar 10;287(5459):1816-20.

120. Wizemann V, Kulz M, Techert F, Nederlof B. Efficacy of haemodiafiltration. Nephrol Dial Transplant. 2001;16 Suppl 4:27-30.

121. Ross BC, Czajkowski L, Hocking D, Margetts M, Webb E, Rothel L, et al. Identification of vaccine candidate antigens from a genomic analysis of Porphyromonas gingivalis. Vaccine. $2001 \mathrm{Jul}$ 20;19(30):4135-42.

122. Laemmli UK. Cleavage of structural proteins during the assembly of the head of bacteriophage T4. Nature. 1970 Aug 15;227(5259):680-5.

123. Sambrook J FE, Maniatis T. . Molecular cloning: A Laboratory manual 2a ed. New York. 1989;Cold Spring Habor Laboratory Press.

124. Altschul SF, Gish W, Miller W, Myers EW, Lipman DJ. Basic local alignment search tool. J Mol Biol. 1990 Oct 5;215(3):403-10.

125. Altschul SF MT, Schäffer AA, Zhang J, Zhang Z, Miller W, Lipman DJ. Gapped BLAST and PSI-BLAST: a new generation of protein database search programs. Nucleic Acids Res. 1997 Sep 1;25(17):3389-402.:3389-402.

126. Schultz J, Milpetz F, Bork P, Ponting CP. SMART, a simple modular architecture research tool: identification of signaling domains. Proc Natl Acad Sci U S A. 1998 May 26;95(11):5857-64.

127. Finn RD, Mistry J, Schuster-Bockler B, Griffiths-Jones S, Hollich V, Lassmann T, et al. Pfam: clans, web tools and services. Nucleic Acids Res. 2006 Jan 1;34(Database issue):D247-51. 
128. Marchler-Bauer A, Bryant SH. CD-Search: protein domain annotations on the fly. Nucleic Acids Res. 2004 Jul 1;32(Web Server issue):W327-31.

129. Marchler-Bauer A, Anderson JB, Cherukuri PF, DeWeese-Scott C, Geer LY, Gwadz M, et al. CDD: a Conserved Domain Database for protein classification. Nucleic Acids Res. 2005 Jan 1;33(Database issue):D192-6.

130. Nakai K, Horton P. PSORT: a program for detecting sorting signals in proteins and predicting their subcellular localization. Trends Biochem Sci. 1999 Jan;24(1):34-6.

131. Gardy JL, Spencer C, Wang K, Ester M, Tusnady GE, Simon I, et al. PSORT-B: Improving protein subcellular localization prediction for Gram-negative bacteria. Nucleic Acids Res. 2003 Jul 1;31(13):3613-7.

132. Petersen TN, Brunak S, von Heijne G, Nielsen H. SignalP 4.0: discriminating signal peptides from transmembrane regions. Nat Methods. 2011;8(10):785-6.

133. Nielsen H, Krogh A. Prediction of signal peptides and signal anchors by a hidden Markov model. Proc Int Conf Intell Syst Mol Biol. 1998;6:122-30.

134. Nielsen H, Engelbrecht J, Brunak S, von Heijne G. Identification of prokaryotic and eukaryotic signal peptides and prediction of their cleavage sites. Protein Eng. 1997 Jan;10(1):1-6.

135. Odintsov SG, Sabala I, Marcyjaniak M, Bochtler M. Latent LytM at 1.3A resolution. J Mol Biol. 2004 Jan 16;335(3):775-85.

136. Silva EF, Medeiros MA, McBride AJ, Matsunaga J, Esteves GS, Ramos JG, et al. The terminal portion of leptospiral immunoglobulin-like protein LigA confers protective immunity against lethal infection in the hamster model of leptospirosis. Vaccine. 2007 Aug 14;25(33):6277-86.

137. Ramos CR, Abreu PA, Nascimento AL, Ho PL. A high-copy T7 Escherichia coli expression vector for the production of recombinant proteins with a minimal N-terminal Histagged fusion peptide. Braz J Med Biol Res. 2004 Aug;37(8):1103-9.

138. Studier FW, Rosenberg AH, Dunn JJ, Dubendorff JW. Use of T7 RNA polymerase to direct expression of cloned genes. Methods Enzymol. 1990;185:60-89.

139. Beuken E, Vink C, Bruggeman CA. One-step procedure for screening recombinant plasmids by size. Biotechniques. 1998 May;24(5):748-50.

140. Sanger F NS, Coulson AR. . DNA sequencing with chain-terminating inhibitor. Proceeding of National Academy of th United States of America. 1977;74:5663-7. 
141. Bradford MM. A rapid and sensitive method for the quantitation of microgram quantities of protein utilizing the principle of protein-dye binding. Anal Biochem. 1976 May 7;72:248-54.

142. Kelly SM, Jess TJ, Price NC. How to study proteins by circular dichroism. Biochim Biophys Acta. 2005 Aug 10;1751(2):119-39.

143. Provencher SW, Glockner J. Estimation of globular protein secondary structure from circular dichroism. Biochemistry. 1981 Jan 6;20(1):33-7.

144. Garnier J, Gibrat JF, Robson B. GOR method for predicting protein secondary structure from amino acid sequence. Methods Enzymol. 1996;266:540-53.

145. Edman P. BG. A protein sequenator. Eur J Biochem. 1967;1:80-91.

146. Towbin H, Staehelin T, Gordon J. Electrophoretic transfer of proteins from polyacrylamide gels to nitrocellulose sheets: procedure and some applications. Proc Natl Acad Sci U S A. 1979 Sep;76(9):4350-4.

147. Shotton DM. Enzymatic Assay of ELASTIN-CONGO RED. Methods Enzymol. 1970;19:113-9.

148. Heussen C, Dowdle EB. Electrophoretic analysis of plasminogen activators in polyacrylamide gels containing sodium dodecyl sulfate and copolymerized substrates. Anal Biochem. 1980 Feb;102(1):196-202.

149. Peters JE, Galloway DR. Purification and characterization of an active fragment of the LasA protein from Pseudomonas aeruginosa: enhancement of elastase activity. J Bacteriol. 1990 May;172(5):2236-40.

150. Simmonds RS, Pearson L, Kennedy RC, Tagg JR. Mode of action of a lysostaphinlike bacteriolytic agent produced by Streptococcus zooepidemicus 4881. Appl Environ Microbiol. 1996 Dec;62(12):4536-41.

151. Firczuk M, Mucha A, Bochtler M. Crystal structures of active LytM. J Mol Biol. 2005 Dec 2;354(3):578-90.

152. Singh VK, Carlos MR, Singh K. Physiological significance of the peptidoglycan hydrolase, LytM, in Staphylococcus aureus. FEMS Microbiol Lett. Oct;311(2):167-75.

153. Johnson WC, Jr. Protein secondary structure and circular dichroism: a practical guide. Proteins. 1990;7(3):205-14.

154. Carvalho E, Barbosa AS, Gomez RM, Cianciarullo AM, Hauk P, Abreu PA, et al. Leptospiral TlyC is an extracellular matrix-binding protein and does not present hemolysin activity. FEBS Lett. 2009 Apr 17;583(8):1381-5.

155. Ministério da Saúde. 2012. 
156. Lo M, Murray GL, Khoo CA, Haake DA, Zuerner RL, Adler B. Transcriptional response of Leptospira interrogans to iron limitation and characterization of a PerR homolog. Infect Immun. 2010 Nov;78(11):4850-9.

157. Nally JE, Artiushin S, Timoney JF. Molecular characterization of thermoinduced immunogenic proteins Q1p42 and Hsp15 of Leptospira interrogans. Infect Immun. 2001 Dec;69(12):7616-24.

158. Matsunaga J, Sanchez Y, Xu X, Haake DA. Osmolarity, a key environmental signal controlling expression of leptospiral proteins LigA and LigB and the extracellular release of LigA. Infect Immun. 2005 Jan;73(1):70-8.

159. Stock JB, Ninfa AJ, Stock AM. Protein phosphorylation and regulation of adaptive responses in bacteria. Microbiol Rev. 1989 Dec;53(4):450-90.

160. Palaniappan RU, Chang YF, Jusuf SS, Artiushin S, Timoney JF, McDonough SP, et al. Cloning and molecular characterization of an immunogenic LigA protein of Leptospira interrogans. Infect Immun. 2002 Nov;70(11):5924-30. 


\section{ANEXOS}

Anexo A - Alinhamento dos genes selecionados com genes homólogos de diferentes genomas de Leptospira. O asterisco indica aminoácidos idênticos, dois pontos indicam aminoácidos com propriedades químicas semelhantes e, um ponto indica aminoácidos com propriedades químicas diferentes. Os aminoácidos sublinhados em preto representam a sequência sinal predita; Os aminácidos sublinhados em vermelho representam os sítios de anelamento aos iniciadores (primers) e os aminoácidos sublinhados em azul representam domínios deduzidos in silico.

\begin{tabular}{|c|c|}
\hline L.b.Hardjo-bovis_L550 & MNKRRSFIL--FLFLFGVSIFSVEDPLPSPFEPYHLSRDFDLNRQKYLQV 48 \\
\hline L.b.Hardjo-bovis_JB197 & MNKRRSFIL--FLFLFGVSIFSVEDPLPSPFEPYHLSRDFDLNRQKYLQV 48 \\
\hline L.i.Copenhageni & MNKKRFFILSLFLILFGVSIFSVENPSFSSFEPYHLSRNFDLNRQKYLQV 50 \\
\hline \multirow[t]{2}{*}{ L.i.Lai } & MNKKRFFILSLFLILFGVSIFSVENPSFSSFE PYHLSRNFDLNRQKYLQV 50 \\
\hline & 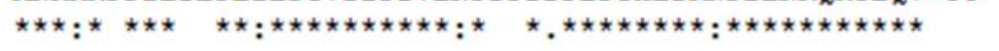 \\
\hline L.b.Hardjo-bovis_L550 & IAIPYKDPMELKLGPENDPVPQNKAPEVAFIKTPGLSFSGMFQPFLFSVV 98 \\
\hline L.b.Hardjo-bovis_JB197 & IAI PYKDPMELKLGPENDPVPQNKAPEVAFIKI PGLSFSGMFQPFLFSVV 98 \\
\hline L.i.Copenhageni & IAIPYKDPMELKLGPENNSISGKNLIETNFIQIPGLSFSGMFQPFLFSVV 100 \\
\hline \multirow[t]{2}{*}{ L.i.Lai } & IAIPYKDPMELKLGPENNSISGKNLIETNFIQIPGLSFSGMFQPFLFSVV 100 \\
\hline & 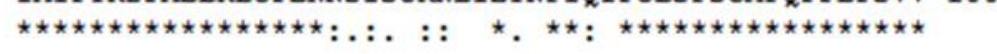 \\
\hline L.b.Hardjo-bovis_L550 & PQESVQFLPISETILVDQVPSRNGKLASGTFSEKRTMDRITDSRNQIPGE 148 \\
\hline L.b.Hardjo-bovis_JB197 & PQESVQFFLISETILVDQVVPSRGKLASGTFSEKRTMDRITDSRNQIPGF 14 \\
\hline L.i.Copenhageni & PSEKIQRELPVSETI FANDVPSRNGKLVSGAFSEKRTMDRITDSRNQIPGF 150 \\
\hline \multirow[t]{2}{*}{ L.i.Lai } & \multirow{2}{*}{ 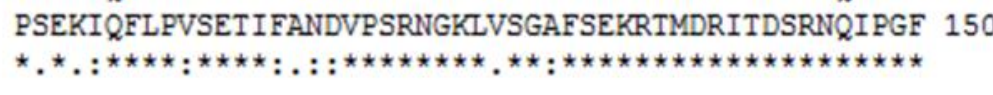 } \\
\hline & \\
\hline L.b.Hardjo-bovis_L550 & GLT---TNSLQNESNSGVMFLYMKRHAGLEMDFNARMIGNQAGLAFLESA 195 \\
\hline L.b.Hardjo-bovis_JB197 & GLT---TNSLQNESNSGVMFLYMKRHAGLEMDFNARMIGNQAGLAFLESA 195 \\
\hline L.i.Copenhageni ${ }^{-}$ & GLTSWNPNSFQNGNSSGVMFLYMKRHAGLEMDFNARMIGNQAGLAFLESA 200 \\
\hline \multirow[t]{2}{*}{ L.i.Lai } & GLTSWNPNSFONGNSSGVMFLYMKRHAGLEMDFNARIIGNQAGLAFLESA 200 \\
\hline & 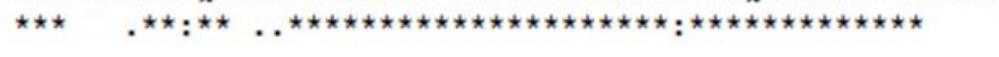 \\
\hline L.b.Hardjo-bovis_L550 & RSTIAFNYSVFPEIGESSKMNFFLESSIKRFQDRGSAYSGEPGNHFRGM 245 \\
\hline L.b.Hardjo-bovis_JB197 & RSTIAFNYSVFPEIGESSKMNFFLFSSIKRFQDRGSAYSGEPGNHFRGM 245 \\
\hline L.i.Copenhageni ${ }^{-}$ & RSTIAFNYSVFPEIGESSKMNFFLQFSSIKRFQDKGLSY-GEPGNNFRGM 249 \\
\hline L.i.Lai & RSTIAFNYSVFPEIGESSKMNFFLOFSSIKRFQDKGLSY-GEPGNNFRGM 249 \\
\hline & 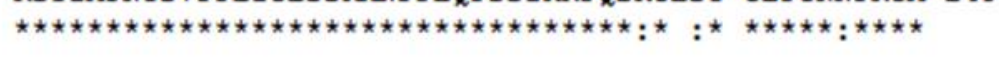 \\
\hline L.b.Hardjo-bovis_L550 & KSYEYYLNPGISFSSRNLSLEGMVRVPVTAGQLGGEQHQWMQDVQGILG 295 \\
\hline L.b.Hardjo-bovis_JB197 & KSYEYYLNPGISFSSRNLSLEGMVRVPVPTAGQLGGEQHQWMQDVQGILG 295 \\
\hline L.i.Copenhageni & KSYEYYLNPGISFSSRNLSLEGMIRVPVPIAAQLGGEQHQWMQDVQGILG 299 \\
\hline L.i.Lai & KSYEYYLNPGISFSSRNLSLEGMIRVPVIAAQLGGEQHQWMQDVQGILG 299 \\
\hline & 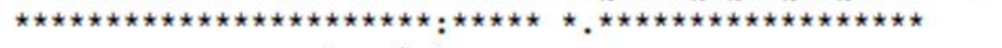 \\
\hline & Identidade \\
\hline L.b.Hardjo-bovis_L550 & IKYSFSETSSK $306 \quad \mathbf{8 5} \%$ \\
\hline L.b.Hardjo-bovis_JB197 & IKYSFSETSSK 306 \\
\hline L.i.Copenhageni & IKYSESETSSK 310 \\
\hline L.i.Lai & 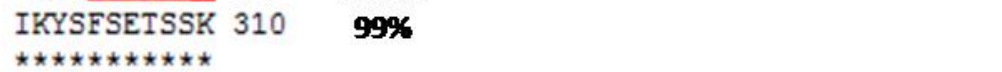 \\
\hline
\end{tabular}




\section{UC10544}

L.b.Hardjo-bovis_JB197

L.b.Hardjo-bovis_L550

L.i.Copenhageni

L.i.Lai

L.b.Hardjo-bovis_JB197

L.b.Hardjo-bovis_L550

L.i. Copenhageni

L.i.Lai

L.b.Hardjo-bovis_JB197

L.b.Hardjo-bovis_L550

L.i. Copenhageni

L.i.Lai

L.b.Hardjo-bovis_JB197

L.b.Hardjo-bovis_L550

L.i.Copenhageni

L.i.Lai

L.b.Hardjo-bovis_JB197

L.b.Hardjo-bovis_L550

L.i.Copenhageni

L.i.Lai

L.b.Hardjo-bovis_JB197

L.b.Hardjo-bovis_L550

L.i.Copenhageni

L.i.Lai

L.b.Hardjo-bovis_JB197

L.b.Hardjo-bovis_L550

L.i. Copenhageni

L.i.Lai

L.b.Hardjo-bovis_JB197

L.b.Hardjo-bovis_L550

L.i.Copenhageni

L.i.Lai

L.b.Hardjo-bovis_JB197

L.b.Hardjo-bovis_L550

L.i.Copenhageni

L.i.Lai

L.b.Hardjo-bovis_JB197

L.b.Hardjo-bovis_L550

L.i. Copenhageni

L.i.Lai

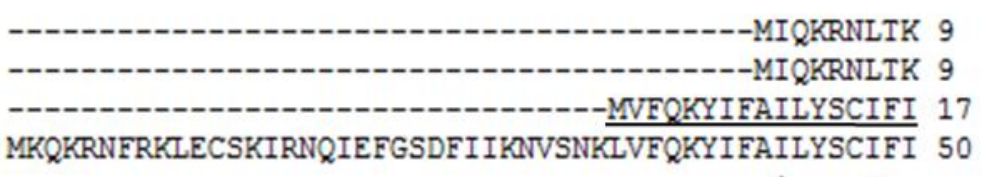

FKCLRKRNRIDGSSFLKRKNATLIYFLWAT-------FHVAPLYS---QEK 50 FKCFRKRNRIDGSSFLKRKNATLIYFLWAT-------FHVAPLYS---QEK 50 FPLSADSQKSDSSTTQTEEKVLNSSHIFPSNIQNKKDSSSSLISSDFLQT 67 FPLSADSQKSDSSTTQTEEKVLNSSHIFPSNIQNKKDSSSSLISSDFLQT 100

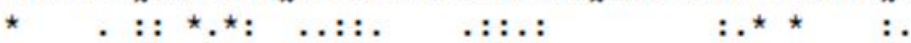

NSDSFTQPETKTQISEQTQPRFAEEVPKKE-------------TEEQERN 87 NSDSFTQPETKIQISEQTQPRFAEEVPKKE-------------TEEQERN 87 SSTNLQSPTNEKSIDKDSSQIQNDDFQSKDEIEKNDHSKNTSSKEASEEN 117 SSTNLQSPTNEKSIDKDSSQIQNDDFQSKDEIEKNDHSKNTSSKEAPEEN 150 $.^{\star} .:{ }^{\star} .:{ }^{\star} .:::$ : : . .*: ${ }^{\star}{ }^{\star}{ }^{\star}$

KYLPSFGFFIDSYYAHNPYRSNSRDNRYLTQPARWDEGNINLAYVDGKVE 137 KYLPSFGFFIDSYYAHNPYRSNSRDNRYLTQPARWDEGNINLAYVDGKVE 137 KQIPKFGFFIDSYYAHNPYRSSSRDNRYLTQPARWDEINVNLAYIDGKIE 167 KQIPKFGFFIDSYYAHNPYRSSSRDNRYLTQPARWDEINVNLAYIDGKIE 200

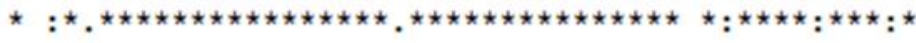

TNQYRGRVAFQFGNSVNANYKNEVSSEKNSNELSVKNIQEAYAGIKLAKN 187 TNQYRGRVAFQFGNSVNANYKNEVSSEKNSNELSVKNIQEAYAGIKLAKN 187 TDQYRGRVAFQFGNSVNSNYKNEVSSEKNSNEVSVRNIQEAYAGIKLAKN 217 TDQYRGRVAFQFGNSVNSNYKNEVSSEKNSNEVSVRNIQEAYAGIKLAKN 250

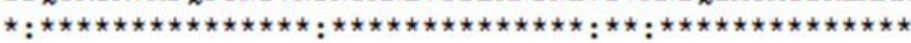

LWLDGGVYFGNIGLENWISQNNWNYSRALALDYVPYYSSGFRLSYQYSDK 237 LWLDGGVYFGNIGLENWISQNNWNYSRALALDYVPYYSSGFRLSYQYSDK 237 LWLDGGIYFGNIGLESWISHNNWNYSRALALDYVPYYSSGFRLSFQYSEK 267 LWLDGGIYFGNIGLESWISHNNWNYSRALALDYVPYYSSGFRLSFQYSEK 300

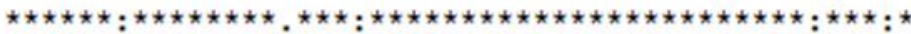

LSFQLHLMNGWNITETNRDKAIGTQIDYKVTDKFKITHNT FVGNEAPDN 287 LSFQLHLMNGWSNITETNRDKAIGIQIDYKVTDKFKITHNTFVGNEAPDN 287 LSFQLHLMNGWSNITETNKDKAIGSQIDYKITDKLKITHNTFVGNEAPDS 317 LSFQLHLMNGWSNITETNKDKAIGSQIDYKITDKLKITHNTFVGNEAPDS 350

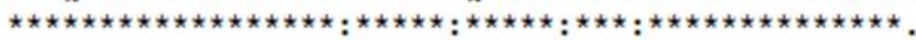

QSRQTRYYNNIILQYHFTKYLIVAGSGDVGIQRVLDPGVRAYRQWYHGTF 337 QSRQTRYYNNIILQYHFTKYLIVAGSGDVGIQRVLDLGVRAYRQWYHGTF 337 QARQTRYYNNLILQYHFTKHFIIAGSGDVGIQRVSDPGVQAYRQWYHGTF 367 QARQTRYYNNLILQYHFTKHFIIAGSGDVGIQRVSDPGVQAYRQWYHGTF 400

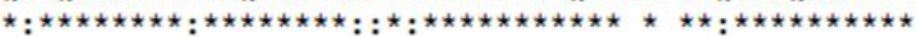

WMTLRPVEKFRTSLRLEKMFDPEQTIIRTGTKNGFLTSGATITFDYIPNE 387 WMTLRPVEKFRTSLRLEKMFDPEQTIIRTGTKNGFLTSGATITFDYIPNE 387 WITWRPIEKFRTSLRLERMFDPEQTIIQTASKNGFLTSGATITLDYIPNE 417 WITWRPIEKFRTSLRLERMFDPEQTIIQTASKNGFLTSGATITLDYIPNE 450

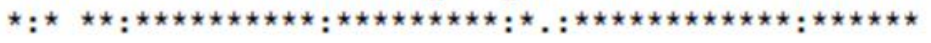

NAMIRLEGRYFRSYDAVFDRDRSKSKEEKFIVFAISLKI 426 NAMIRLEGRYFRSYDAVFDRDRSKSKEEKFIVFAISLKI 426 NALVRLEGRYFRSYDAVFDRDQSKSKEEKFIVFAISVKI 456 NALVRLEGRYFRSYDAVFDRDQSKSKEEKFIVFAISVKI 489 Identidade 72\% $72 \%$ $100 \%$ 99\% 


\section{UC11211}

L.b.Hardjo-bovis_L550

L.b.Hardjo-bovis_JB197

L.i.Lai

L.i.Copenhageni

L.b.Hardjo-bovis_L550

L.b.Hardjo-bovis_JB197

L.i.Lai

L.i.Copenhageni

L.b.Hardjo-bovis_L550

L.b.Hardjo-bovis_JB197

L.i.Lai

L.i.Copenhageni

L.b.Hardjo-bovis_L550

L.b.Hardjo-bovis_JB197

L.i.Lai

L.i.Copenhageni

L.b.Hardjo-bovis_L550

L.b.Hardjo-bovis_JB197

L.i.Lai

L.i.Copenhageni

L.b.Hardjo-bovis_L550

L.b.Hardjo-bovis_JB197

L.i.Lai

L.i.Copenhageni

L.b.Hardjo-bovis_L550

L.b.Hardjo-bovis_JB197

L.i.Lai

L.i.Copenhageni

L.b.Hardjo-bovis_L550

L.b.Hardjo-bovis_JB197

L.i.Lai

L.i.Copenhageni
MANQRIKFQKTPFSLAASFPLRLTFLISVFLFFSVSLSAQEQKKSAFLGS 50 MANQRIKFQKT PFSLAASFPLRLTFLISVFLFFSVSLSAQEQKKSAFLGS 50 ----MIFKKNPFLIS--------FFLLFILLPFSLSAQEQRKSTFLGS 36

SLIHMPSTEDVGKNGLDFRFNHRFGNAKSASYDFLGLDNGANTQLSLDYG 100 SLIHMPSTEDVGKNGLDFRFNHRFGNAKSASYDFLGLDNGANTQLSLDYG 100 SLIHMPSTEDVGKNGLDFRFNHRFGNAKSTSYDFFGLDNGANTQLSLDYG 86

VIDRLTIGIARTSFQKTYEARGKIRLLTQDSSFPVTISFFGVFGQETEKQ 150 VIDRLTIGIARTSFQKTYEARGKIRLLTQDSSFPVIISFFGVFGQETEKQ 150 LTDRITIGIARTSFQKTYEARGKIRLLTQDSNFPVIISFFGVFGQETEEQ 136 --------MKQHSLKK-----------LRRSIFVVLLTFF---------- 21 $::^{\star}::^{\star} \quad: \star \star \star:: \star \star$

EKFYGPYLKISLGLATFDPEATKKLNTYELTYPDRQSMLASFLISRRFGE 200 EKFYGPYLKISLGLATFDPEATKKLNTYELTYPDRQSMLASFLISRRFGE 200 SKFYGPYLKVSTGFPSFDSQLEKKLNTYELSDSDRQSALTSFLISKRFGD 186 -------LAASDSYADESEKKTYSTKNIDVTVKDKD-GYNHFLV------ 57

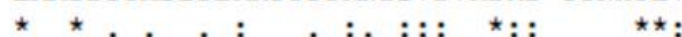

VFSLQLSPMFVHRNFVKEHISNDRMGLDVSFRIHLFKRLDFTFGIILTSK 250 VFSLQLSPMFVHRNFVKEHISNDRMGLDVSFRIHLFKRLDFTFGTILTSK 250 LFSLQLSPMFVHRNFVKEHLSNDRTGLDVSFRIHVFKRLDFTFGIILTPK 236 -FTKVMT PDKSYVAYNVE FWVNN-----YVYSEMDTFSQISFKAG------ 96

${ }^{\star}: \quad:{ }^{\star} \quad: \quad:{ }^{\star},{ }^{\star}: \quad{ }^{\star} \quad .:{ }^{\star} .:: .^{\star} .{ }^{\star}$

RDYIGDSYAAENRKTKINGVEYSASEVNDLIARGKTIDTVFNNILLSKPV 300 RDYIGDSYAAENRKTKINGVEYSASEVNDLIARGKIIDTVFNNILLSKPV 300 RDYIGDSYTAEDRKTKINGLEYSTSEANELIANGRTLDVIVNNILLSKPV 286 --------KKSFNGNFYKSDVSSNALVLYFYMEESVIKGLLASSA 133

$$
\star \ldots: \star \star \quad \star .: \text {. } \quad: \quad: . \quad:: \quad . \quad:{ }^{\star}: \ldots
$$

EYMSVPLSFGVDFETGGHVFQLFVTNSRSIAHTQLLRGADYDYSKKEWTL 350 EYMSVPLSFGVDFETGGHVFQLFVTNSRSIAHTQLLRGADYDYSKKEWTL 350 EYMSVPMSFGVDFETGGHVFQLFVTNSRSIAHTQLLRGADYNYDKKEWTL 336 DRLSIFQKNKTVFEYTIATKDNFKKALKEITTVE---------------- 167

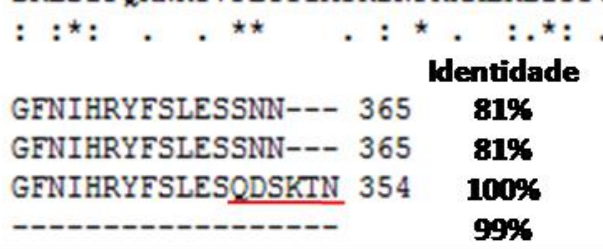




\section{UC10291}

L.b.Hardjo-bovis_JB197

L.b.Hardjo-bovis_L550

L.i.Copenhageni

L.i.Lai

L.b.Hardjo-bovis_JB197

L.b.Hardjo-bovis_L550

L.i.Copenhageni

L.i.Lai

L.b.Hardjo-bovis_JB197

L.b.Hardjo-bovis_L550

L.i. Copenhageni

L.i.Lai

L.b.Hardjo-bovis_JB197

L.b.Hardjo-bovis_L550

L.i.Copenhageni

L.i.Lai
MKQNLNNSRIRRFIYSVFLILFLFSSITAFDVYAQEDEKKTHSTKNIDIT 50 MKQNLNNSRIRRFIYSVFLILFLFSSITAFDVYAQEDEKKTHSTKNIDIT 50 MKQHS-LKKLRRSIFVVLLTFFLAAS----DSYADESEKKTYSTKNIDVT 45 MKQHS-LKKLRRSIFVVLLTFFLAAS----DSYADESEKKTYSTKNIDVT 45

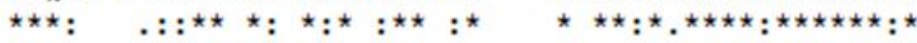

VKDKDGYNHFLVFTKVTTPDKSYIAYNVEFWVNNYVYSGGEEFSQISFKA 100 VKDKDGYNHFLVFTKVTTPDKSYIAYNVEFWVNNYVYSGGEEFSQISFKA 100 VKDKDGYNHFLVFTKVMT PDKSYVAYNVEFWVNNYVYSEMDTFSQISFKA 95 VKDKDGYNHFLVFTKVMT PDKSYVAYNVEFWVNNYVYSEMDTFSQISFKA 95

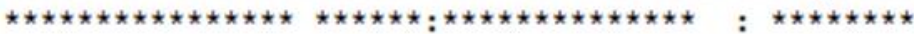

GKKSLNGSYYKYDTSSGAIVLYFYMDETATKELLTNSGSVDKITISQKANK 150 GKKSLNGSYYKYDTSSGAIVLYFYMDETATKELLTNSGSVDKITISQKANK 150 GKKSFNGNFYKSDVSSNALVLYFYMEESVIKGLLAS--SADRLSIFQKRNK 143 GKKSFNGNFYKSDVSSNALVLYFYMEESVIKGLLAS--SADRLSIFQKRNK 143

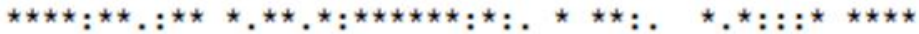

\section{Identidade}

TVSEYILATKDNFKKALKEIMAVE $174 \quad \mathbf{6 8 \%}$ TVSEYILATKDNFKKALKEIMAAE $174 \quad \mathbf{6 8 \%}$ TVFEYTIATKDNFKKALKEITTVE $167 \quad$ 100\% MVFEYTIATKDNFKKALKEITTVE 167 99\%

\begin{tabular}{|c|c|c|}
\hline UC10359 & & \\
\hline L.b.Hardjo-bovis_L550 & MAFLKIRRILPGAAGLILVCGISVSGDPGRDRLGALLGRMGEISSLRASV 50 & \\
\hline L.b.Hardjo-bovis_JB197 & MAFLKIRRILPGAAGLILVCGISVSGDPGRDRLGALLGRMGEISSLRASV 50 & \\
\hline L.i.Copenhageni - & MAFLKIRRILPGAAGLILVCGISVSGDPGRDRLGALLGRMSEISSLRASV 50 & \\
\hline \multirow[t]{2}{*}{ L.i.Lai } & MAFLKIRRILPGAAGLILVCGISVSGDPGRDRLGALLGRMSEISSLRASV 50 & \\
\hline & 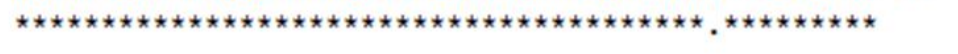 & \\
\hline L.b.Hardjo-bovis_L550 & IINNEISGTLSYKKPNYLHVKFSDGRVVSSNGRFLWFYSPARAIVGKQDL 100 & \\
\hline L.b.Hardjo-bovis_JB197 & TINNE ISGTLSYKKPNYLHVKFSDGRVVSSNGRFLWFYSPARAIVGKQDL 100 & \\
\hline L.i.Copenhageni & TIMNEISGTLSFKKPNYLHVKFSDGRVVSSNGRFLWFYSPARAIVGKQ̈DL 100 & \\
\hline \multirow[t]{2}{*}{ L.i.Lai } & TINNEISGTLSFKKPNYLHVKFSDGRVVSSNGRFLWFYSPARAIVGKQDL 100 & \\
\hline & 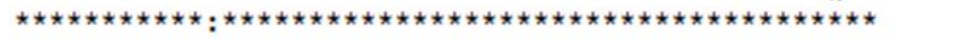 & \\
\hline L.b.Hardjo-bovis_L550 & RGISGGVFGLLSGYEDVSQVGGSIRLKSSTKSYEEIVVTMNPDNTPKSLR 150 & \\
\hline L.b.Hardjo-bovis_JB197 & RGTSGGVFGLLSGYEDVSQVGGSIRLKSSTKSYEEIVVTMNPDNTPKSLR 150 & \\
\hline L.i.Copenhageni & RGTSGGVFGLLSGYEEVTQVGGSIRLKSPTKTYEEIVVTMNSDNTPKSLR 150 & \\
\hline \multirow[t]{3}{*}{ L.i.Lai } & RGTSGGVFGLLSGYEEVTQVGGSIRLKSPTKTYEEIVVTMNSDNTPKSLR 150 & \\
\hline & 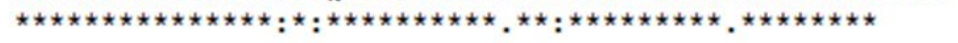 & \\
\hline & \multicolumn{2}{|c|}{ Identidade } \\
\hline L.b.Hardjo-bovis_L550 & MKHRGSGEYTSISFSGVQTNVGLSASLFNESAPSSAQIVENPLNEKE 197 & $95 \%$ \\
\hline L.b.Hardjo-bovis_JB197 & MKHRGSGEYTSISFSGVQTNVGLSASLFNFSAPSSAQIVENPLNEKE 197 & 95\% \\
\hline L.i.Copenhageni & MKKRGSSEYTSISFSGVQTINVGLSASLFNFSAPSSAQIVENPLNEKE 197 & $100 \%$ \\
\hline L.i.Lai & MKKRGSSEYTSISFSGVQNTNVGLSASLFNFSAPSSAQRIVENPLNEKE 197 & $100 \%$ \\
\hline
\end{tabular}

Os aminoácidos sublinhados em azul indicam um domínio semelhante ao domínio da lipoproteína carreadora LoaL
MAFLKIRRILPGAAGLILVCGISVSGDPGRDRLGALIGRMGEISSLRASV 50 MAFLKIRRILPGAAGLILVCGISVSGDPGRDRLGALLGRMSEISSLRASV 50

IINNEISGTLSYKKPNYLHVKFSDGRVVSSNGRFLWFYSPARAIVGKQDL 100 IINNEISGTLSYKKPNYLHVKFSDGRVVSSNGRFLWFYSPARAIVGKQDL 10 INNEISGTLSFKKPNYLHVKFSDGRVVSSNGRFLWFYSPARAIVGKQDL 10

RGISGGVFGLLSGYEDVSQVGGSIRLKSSTKSYEEIVVIMNPDNTPKSLR 150 MKHRGSGEYTSISFSGVQTNVGLSASLFNFSAPSSAQIVENPLNEKE 197 MKHRGSGEYTSISFSGVQTNVGLSASLFNFSAPSSAQIVENPLNEKE 197 MKKRGSSEYTSISFSGVQTNVGISASLFNFSAPSSAQIVENPLNEKE 197

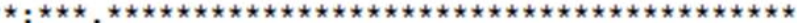




\section{UC10881}

L.i.Copenhageni L.i.Lai

L.i.Copenhageni L.i.Lai

L.i.Copenhageni L.i.Lai

L.i. Copenhageni L.i.Lai

L.i.Copenhageni L.i.Lai

L.i.Copenhageni L.i.Lai

L.i. Copenhageni L.i.Lai

L.i.Copenhageni L.i.Lai

L.i.Copenhageni L.i.Lai

L.i. Copenhageni L.i.Lai

L.i.Copenhageni L.i.Lai

L.i.Copenhageni L.i.Lai

L.i.Copenhageni L.i.Lai

L.i.Copenhageni L.i.Lai

L.i. Copenhageni L.i.Lai

L.i.Copenhageni L.i.Lai
MFAFNAQPFFSSLNOKSLQRKFFLVFPVLLSLISAGILWAKASLRLKI FANSKSDPPTQI 60 MFAFNAQPFFSSLNQKSLQRKFFLVFPVLLSLTSAGTLWAKASLRLKI FANSKSDPPTQI 60

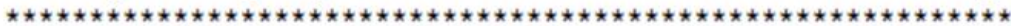

WVRGNGYSKVFSLSDQSSELTIDLKEQGVYDVILTFKSGEMEHKFVTVDSDEKNLEFVQK 120 WVRGNGYSKVFSLSDQSSELTIDLKEQGVYDVILTFKSGEMEHKFVTVDSDEKNLEFVQK 120

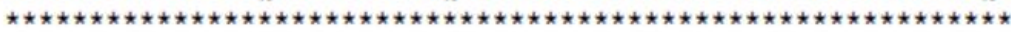

TKKVTNGINVVGKRPEAPPNYVLSOEDAIRMPGGEGDALKAVQSMPGISPMYQMYTGASF 180 TKKVTNGINVVGKRPEAPPNYVLSQEDAIRMPGGFGDALKAVQSMPGISPMYQMYTGASF 180

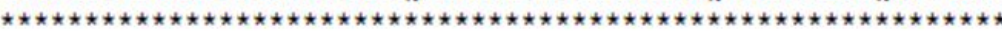

QSAIOTFAOATNPDKPDKPNGEKGFLVMRGAGARANQFYFNGLPMSYPFHADGLTSVINN 240 QSAIQTFAQATNPDKPDKPNGEKGFLVMRGAGARANQFYFNGLPMSYPFHADGLTSVINN 240

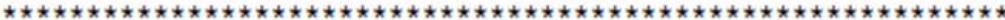

NAIRSLELYSGSYSARYGFATGGIINIEGFQKRDSNLSVAHLNAFLTDVYTYRNITKDLN 300 NAIRSLELYSGSYSARYGFATGGIINIEGFQKRDSNLSVAHLNAFLTDVYTYRNITKDLN 300

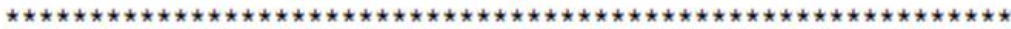

VSVSGKKYYPNIVFGRVPNLIPAETFLADYNDYQARIGWDISENHSLSFQTFGAKDKRYP 360 VSVSGKKYYPNIVFGRVPNLIPAETFLVDYNDYQARIGWDISENHSLSFQTFGAKDKRYP 360

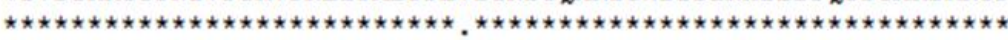

FKELSQYNPKETAQSFANPPSDADAARLDRIFRTDGIQHIWKPKSSITNTFNVSRNYFNE 420 FKELSQYNPKETAQSFANPPSDADAARLDRIFRTDGIQHIWKPKSSITNTFNVSRNYFNE 420

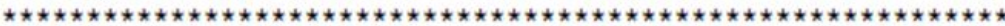

VTENGLDMLVLDITKIGYPPSLYKRVQTIQNEYFNDLRQIENVSEVELLKRNWKIVFGGQ 480 VIENGLDMLVLDITKIGYPPSLYKRVQTIQNEYFNDLRQIENVSEVELLKRNWKIVFGGQ 480

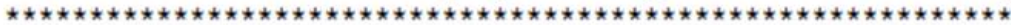

YREVDTGYKGKVSQIDLDPTYNFIHQQLLNSSDVKSVLEGDSVRTRQIGTFFENRFKFYD 540 YREVDTGYKGKVSQIDLDPTYNFIHQQLLNSSDVKSVLEGDSVRTRQIGTFFENRFKFYD 540

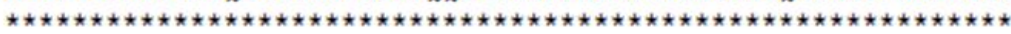

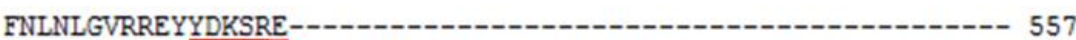
FNLNLGVRREYYDKSREWKTAPRVAISKEIAYTQSRIFAGYGKHFQAPSDVSRYSARTGN 600

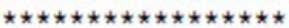

PNLKMEESEHAEIGWDQKIGNFWNIKIEGYQNTFSNLSIADPYAMDPFSRNRDLMRESLD 660 PNADLSLVRRSNLNYSNSMTGYSRGVEVFIKKEASAESGLYGWISYTKSITKRNRNLPEL 720

TKQEYSSWLAESSAKDLIHQENTDYYYANFYRDGSYDVLFKNSKEELYDFDRTHMFNMVI 780

GWKFGEKAQIGLRGTYLTNYAYT PVVGSKSITSEQFNSQLLPSAAPPPPSSSSSSSSSLF 840

SIYQPVYSDMLRSARLPHYHQFDLRFDRFIPTSWGRMTAYLELVNITGSRIAVSADTFVP 900

IFPFVPGANPETQYIYLNGLQSLRTEKNKIPYLNFGIEFRF 941

Os aminoácidos sublinhados em azul indicam um domínio semelhante ao receptor TomB dependente. 


\section{UC13435}

L.i.Copenhageni

L.i.Lai

MIYSKISFYGIITVELFGIFSVIQAQTLDQNQYQKIKAVVTQTGHIEKETLVREVYAINS 60

L.b.Hardjo_JB197 MAKVKISFHSIIVAFLFGIPFGIQAQVLDQSQYQKIKAVVTQTGHIEKETLMREIYAINP 60

L.b_Hardjo_L550 MMKVKISFHSIIVAFLFGIPFGIQAQVLDQSQYQKIKAVVTQTGHIEKETLMREIYAINP 60

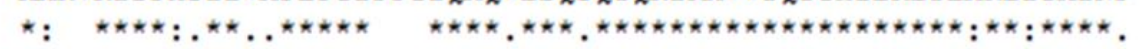

L.i.Copenhageni

NPQEYLIALTKDPDLRVYALSQINELIADFGGNSAINYLESTIANENAHPSIRSSAAFSY 120

L.i.Lai

NPQEYLIALTKDPDLRVYALSQINELIADFGGNSAINYLESTIANENAHPSIRSSAAFSY 120

L.b.Hardjo_JB197 NPQEYLVAIAKDPELRVYAISQLNELIADFGANSARDYLESTISNESTHPSIRNSAVFSY 120

L.b_Hardjo_L550 NPQEYLVAIAKDPELRVYAISQLNELIADFGANSARDYLESTISNESTHPSIRNSAVFSY 120

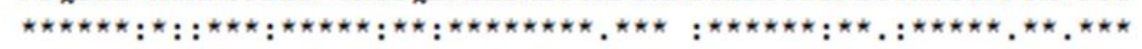

L.i. Copenhageni

GKTFYFSDRIRTENFLNRYSANDQIGVSIRNTLRGLRTGKINSIRFSERLKKENLNRIQN 180

L.i.Lai GKTFYFSDRIRTENFLNRYSANDQIGVSIRNTLRGLRTGKINSIRFSERLKKENLNRIQN 180

L.b.Hardjo_JB197 GKTFYFSDRNHAENFLKRFSSHDRIGTFVQNTLKELRMGKISSIRFSEKLKKENMDRIKN 180

L.b_Hardjo_L550 GKTFYFSDRNHAENFLKRFSSHDRIGTFVQNTLKELRMGKISSIRFSEKLKKENMDRIKN 180

L.i. Copenhageni

L.i.Lai

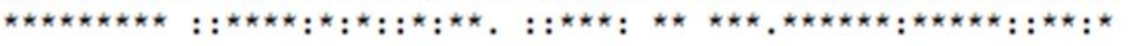
Identidade

KNLKKTDPSN--- $190 \quad 100 \%$

KNLKKTDPSN--- $190 \quad 100 \%$

L.b.Hardjo_JB197 GNLRMPDPSIKNP $193 \quad 71 \%$

L.b_Hardjo_L550 GNLRMPDPSIKNP $193 \quad 71 \%$ 


\section{UC11399}

L.b.Hardjo_JB197

L.b.Hardo_L550

L.i.Copenhageni

L.i.Lai

L.b.Hardjo_JB197

L.b.Hardo_L550

L.i.Copenhageni

L.i.Lai

L.b.Hardjo_JB197

L.b.Hardo_L550

L.i.Copenhageni

L.i.Lai

L.b.Hardjo_JB197

L.b.Hardo_L550

L.i. Copenhageni

L.i.Lai

L.b.Hardjo_JB197

L.b.Hardo_L550

L.i.Copenhageni

L.i.Lai

L.b.Hardjo_JB197

L.b.Hardo_L550

L.i.Copenhageni

L.i.Lai

L.b.Hardjo_JB197

L.b.Hardo L550

L.i.Copenhageni

L.i.Lai
MSN---IFKLQNSIIIFGFSIFFTFTSIIGTPISYGNLGSETDFIDFGRWTTTPFSYSVS 57

MSN---IFKLQNSIIIFGFSIFFTFTSIIGTPISYGNLGSETDFIDFGRWITTPFSYSVS 57

MFDRLYFCKLEYLILLILFIISFASTSAVSAPIAYGNLGSEVDFIDFGRWTTTPFSYSVS 60 MFNRFYFCKLEYLILLILFIISFASTSAVSAPIAYGNLGSEVDFIDFGRWTTTPFSYSVS 60

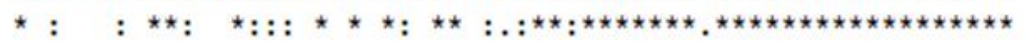

SSFSSEYGGFNLFDSDSNTHWYSTNRSGSEWIIVDFGSKRLINGLEITVPLFRKERAAKK 117 SSFSSEYGGFNLFDSDSNTHWYSTNRSGSEWI IVDFGSKRLINGLEITVPLFRKERAAKK 117 SSFSAEYGGFNLFDSDPNTHWYSVNRSDSEWVIVDFGSKRLINGLEITVPIFKKERAVKK 120 SSFSAEYGGFNLFDSDPNTHWYSVNRDSEWVIVDFGSKRLINGLEITVPIFKKERAVKK 120

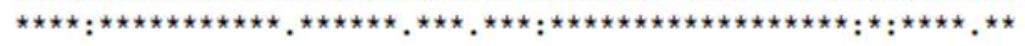

YEVQVLIRDDWRTIFVNQDVALHNFHKLENLDASVLRIYFPDTTDRGVVISDLKLFLNQQ 177 YEVQVLIRDDNRT IFVNQDVALHNFHKLENLDASVLRIYFPDTTDRGVVISDLKLFLNQQ 177 YEIQVLIRDDWRIILTNQNVELHNFHKL GNIDASVLRIYFPDSTNREVVISDLKLFLNQK 180 YEIQVLIRDDWRIILTNQNVLLHNFKLGNIDASVLRIYFPDSTNREVVISDLKLFLNQK 180

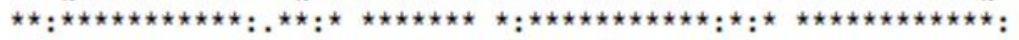

LLNGIEPRLRGYTFPVPDGLIPSLDFQLPNAPRVYRNGVHKGIDIYKKKEPSGQIRNLNF 237 LLNGIEPRLRGYTFPVPDGLIPSLDFQLPNAPRVYRNGVHKGIDIYKKKEPSGQIRNLNF 237 LLNGIEPRLRGYSFPVPDGISSFDSQLPNAPRTYRNGVHKGIDIYKKKELDGQIRNLNF 240 LLNGIEPRLRGYSFPVPDGLISSFDSQLPNAPRTYRNGVHKGIDIYKKKELDGQIRNLNF 240

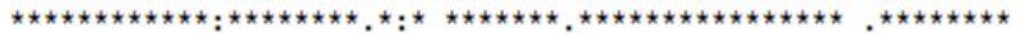

QDEAVSPADGVIVRADHSYFPMTSADYEYHTSQSQKGTVTYVEKDFGGRQVWIDHGHGVM 297 QDEAVSPADGVIVRADHSYFPMTSADYEYHTSQSQKGTVTYVEKDFGGRQVWIDHGHGVM 297 QDEIISPADGIVIRADHSYSPMTLSDYEYHTTQSQKGTVTYVEKDFGGRQVWIDHGHGVM 300 QDEIISPADGIVIRADHSYSPMTLSDYEYHTTQSQKGTVTYVEKDFGGRQVWIDHGHGVM 300

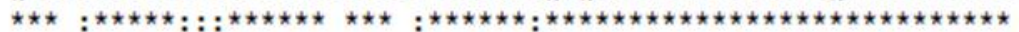

SSFNHLSSIRKNLKIGNKVKRGEVIGI IGNSGLMEEAKGITDNAHLHFEIWVDGEFFGNG 357 SSFNHLSSIRKALKIGNKVKRGEVIGIIGNSGLMEEAKGITDNAHLHFEIWVDGEFFGNG 357 TSFNHLSSIHKNIKVGEKVKQGESIGTVGNSGLLEEAKNISDNIHLHFEIWVDGEFLGNG 360 TSFNHLSSIHKNIKVGEKVKQGESIGTVGNSGLLEEAKNISDNIHLHFEIWVDGEFLGNG 360

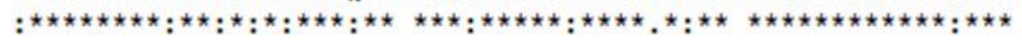

VAPVQVRKMLQFFFKRNGAD 377

VAPVQVRKMLQFFFKRNGAD 377

LPPAQVRKLLQFFFKRNGVD 380

LPPAQVRKLLQFFFKRNGVD 380

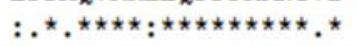

Os aminoácidos sublinhados em pontilhados azuis indicam o domínio semelhante aos fatores V e VII da cascata de coagulação. Os aminoácidos sublinhados com linha contínua azul indicam o domínio semelhante à metaloprotease da família M23. 


\section{UC10642}

L.b.Hardjo-bovis_L550

L.b.Hardjo-bovis_JB197

L.i.Copenhageni

L.i.Lai

L.b.Hardjo-bovis_L550

L.b.Hardjo-bovis_JB197

L.i.Copenhageni

L.i.Lai

L.b.Hardjo-bovis_L550

L.b.Hardjo-bovis_JB197

L.i.Copenhageni

L.i.Lai

L.b.Hardjo-bovis_L550

L.b.Hardjo-bovis_JB197

L.i.Copenhageni

L.i.Lai

L.b.Hardjo-bovis_L550

L.b.Hardjo-bovis_JB197

L.i.Copenhageni

L.i.Lai

L.b.Hardjo-bovis_L550

L.b.Hardjo-bovis_JB197

L.i.Copenhageni

L.i.Lai

L.b.Hardjo-bovis_L550

L.b.Hardjo-bovis_JB197

L.i.Copenhageni

L.i.Lai
MKILNSNHFFKKFPGVSLMEIFCICLLLDPIWIFGDTLILKDGRKMGNVR 50 MKILNSNHFFKKFPGVSLMEIFCICLLLDPIWIFGDTLILKDGRKMGNVR 50 MPYRN----IQRIG--AFIIILCFHILPNSGIISADTIILKDGQTFENVK 44 MPYRN----IQRIG--AFIVILCFHILPNSGIISADTIILKDGQTFENVK 44

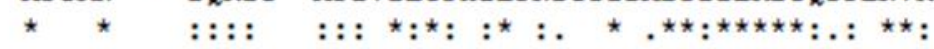

TSLREDHVLVEDETGKVEKIDLTLVEKILVSEIKKPEGE-EKQKEHNNIK 99 TSLREDHVLVEDETGKVEKIDLTLVEKILVSEIKKPEGE-EKQKEHNNIK 99 TSLRQDHVLVQDEKGKIEKIDLTLVEKILVSEIKKSEVVQEEKKEYINIK 94 TSLRQDHVLVQDEKGKIEKIDLTLVEKILVSEIKKSEVVQEEKKEYINIK 94

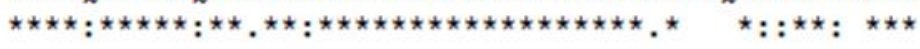

KFYFSWNLSSWSTKVTEKMNFNRGYNITDLITGVIYIDPYIEKRYTVNTK 149 KFYFSWNLSSWSTKVTEKMNFNRGYNITDLITGVIYIDPYIEKRYTVNTK 149 KFYFSLNGSSWNTKVSEGINFNRGYSLTDVRTNVVNIDPYFERRYTVNVR 144 KFYFSLNGSSWNTKVSEGINFNRGYSLTDVRTNVVNIDPYFERRYTVNVR 144

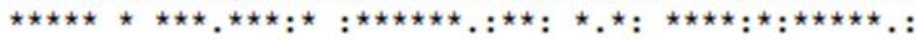

TTSFNGEYR-YNLNLSFLFGIELNSYSFPDRKISPLVGILMNSNFNSTPE 198 TTSFNGEYR-YNLNLSFLFGIELNSYSFPDRKISPLVGILMNSNFNSTPE 198 TLSLNGEYRPTKSNFGFSLGLEQNSYSFPDQRISPLIGMNTYIALNTTQE 194 TLSLNGEYRPTKSNFGFSLGLEQNSYSFPDQRISPLIGMNTYIALNTTQE 194

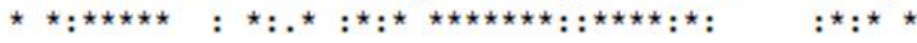

YQTLSSISINLFLFEGNFNFDKQGNDKFGIETLSLLPGMKYYFPLSESIF 248 YQTLSSISINLFLFEGNFNFDKQGNDKFGIETLSLLPGMKYYFPLSESIF 248 YQTLSSISLSSFLTNQLDGKFTQSSGKFSIETLSLSPGVKYYIPISESFF 244 YQTLSSISLSSFLTNQLDGKFTQSSGKFSIETLSLSPGVKYYIPISESFF 244

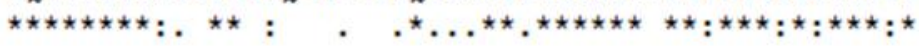

WFTQVGLGVGKSIESGVHSK--VQTVLFVGTGIQWELESYFFNIALQYRK 296 WFTQVGLGVGKSIESGVHSK--VQTVLFVGTGIQWELESYFFNIALQYRK 296 WFVQGGFGFGKSYENGIYSKPLTQTVLLVGTGIQWESDLYFFNAALQFRK 294 WFVQGGFGFGKSYENGIYSKPLTQTVLLVGTGIQWESDLYFFNAALQFRK 294

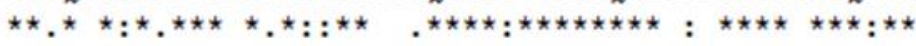

Identidade

TDLIGATQSYHFNEPIFMIGGGLKL $321 \quad \mathbf{5 9 \%}$

TDLIGATQSYHFNEPIFMIGGGLKL $321 \quad \mathbf{5 9 \%}$ TDLVGSVNSYHFQEPIFMIGIGFKL $319 \quad \mathbf{1 0 0 \%}$ TDLVGSVNSYHFQEPIFMIGTGFKL 319 99\% 


\section{UC12558}

L.b.Hardjo-bovis_JB197

L.b.Hardjo-bovis_L550

L.i.Copenhageni

L.i.Lai

L.b.Hardjo-bovis_JB197

L.b.Hardjo-bovis_L550

L.i.Copenhageni

L.i.Lai

L.b.Hardjo-bovis_JB197

L.b.Hardjo-bovis L550

L.i.Copenhageni

L.i.Lai

L.b.Hardjo-bovis_JB197

L.b.Hardjo-bovis_L550

L.i.Copenhageni

L.i.Lai

L.b.Hardjo-bovis_JB197

L.b.Hardjo-bovis_L550

L.i. Copenhageni

L.i.Lai

L.b.Hardjo-bovis_JB197

L.b.Hardjo-bovis_L550

L.i. Copenhageni

L.i.Lai

L.b.Hardjo-bovis_JB197

L.b.Hardjo-bovis_L550

L.i. Copenhageni

L.i.Lai

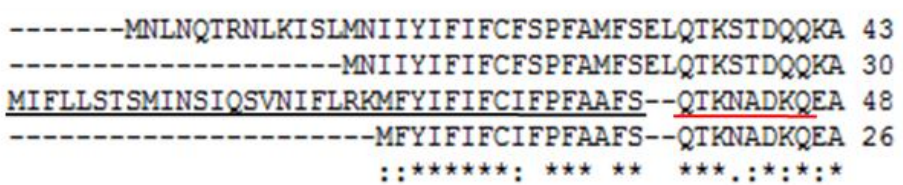

------MNLNQTRNLKISLMNI IYIFIFCFSPFAMFSELQTKSTDQQKA 43 -MNIIYIFIFCFSPFAMFSELQTKSTDQQKA 30 MIFLLSTSMINSIOSVNIFLRKMFYIFIFCIFPFAAFS--QTKNADKQEA 48 -MFYIFIFCIFPFAAFS--QTKNADKQEA 26

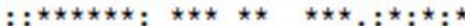

TPFIRINLETQTEQILPNQSTSVKAKEPQKRVDQKKGTWSFQWGYNRDSY 93 TPFIRINLETQTEQILPNQSTSVKAKE PQKRVDQKKGTWSFQWGYNRDSY 80 IPFAQINPETKTD-------LSSKQTPRRVDQRKGSWSFQWGYNRDSY 89 IPFAQINPETKTD--------LSSKQTPRRVDQRKGSWSFQWGYNRDSY 67

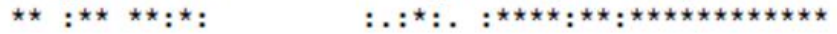

TQSDINFHGPEYKFTLKDVIAKDKPERFDPSVYLNPSIWEIPQYNFRLTY 143 TQSDINFHGPEYKFTLKDVIAKDKPERFDPSVYLNPSIWEIPQYNFRLTY 130 TQSDISFHGPGYHFTLKDVVARDKPEKFNPSVYLNPSLWEIPQYNFRLTY 139 TQSDISFHGPGYHFTLKDVVARDKPEKFNPSVYLNPSLWEIPQYNFRLTY 117

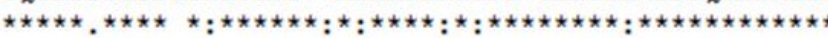

YFTDKFFFAFGQDHMKYYMSRGQAANIYGYIDPISIQKAHLRTSPESAVY 193 YFTDKFFFAFGQDHMKYVMSRGQAANIYGYIDPISIQKAHLRTSPESAVY 180 YFSDKFFIAFGQDHMKYVMSRGQAANIYGYIDPLVIQKAHLATSPESSVY 189 YFSDKFFIAFGQDHMKYVMSRGQAANIYGYIDPLVIQKAHLATSPESSVY 167

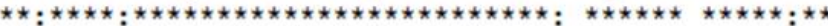

LYLFPDAYKKLEGYHNGETINITPDFLKFEHTDGLNFLYMDVGMIQPLLI 243 LYLFPDAYKKLEGYHNGETINITPDFLKFEHTDGLNFLYMDVGMIQPLLI 230 LYLFPDAYKKWEGYHNGETVNITPDFLKFEHTDGLNFLYLDVGMIQPIWV 239 LYLFPDAYKKWEGYHNGETVNITPDFLKFEHTDGLNFLYLDVGMIQPIWV 217

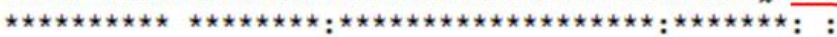

SSDGENALSFVASVGGGPIICRSDVRLFGEGKNNHFHTSGYGVSGYVASR 293 SSDGENALSFVASVGGGPIICRSDVRLFGEGKNNHFHTSGYGVSGYVASR 280

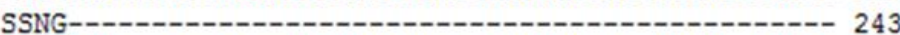
SSNGENALSFVSSIGGGPIVCRSDVRLFGEGKNNHFHTSGYGVSGYVAAR 267 $\star \star: \star$

VDIYRLVFFELGAKGGYIDLSNIFTNGHSKDRASQNFGFLELVIFGGVNF 343 VDIYRLVFFELGAKGGYIDLSNIFTNGHSKDRASQNFGFLELVIFGGVNF 330 ADIFRSVFFEFGGKGGYIDLPNIFTNGHSKDRASQNFGFLELVIFGGVNF 317

Identidade
$73 \%$
$73 \%$
$100 \%$
$90 \%$

\section{UC10468}

L.i. Copenhageni L.i.Lai

L.i. Copenhageni L.i.Lai

L.i. Copenhageni L.i.Lai

L.i. Copenhageni L.i.Lai

L.i. Copenhageni L.i.Lai
MYKFLKYSCILFLLLEVFGCFVSRKLIFIAQGKDTLPSYSGTLLQIQNEDRIVYAYFTRN 60 MYKFLKYSCILFLLLEVFGCFVSRKLIFIAQGKDTLPSYSGTLLQIQNEDRIVYAYFTRN 60

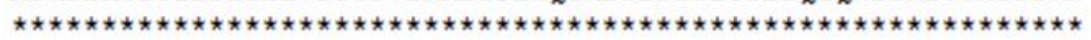

SSRLAVVFHGQHGTLQSMSYLGAKLSQMGFSVLLVEYPGYGKAKRYSSSESNIYSDADAA 120 SSRLAVVFHGQHGTLQSMSYLGAKLSQMGFSVLLVEYPGYGKA.KRYSSSESNIYSDADAA 120

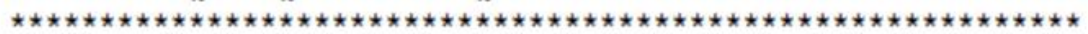

INFVQKNFSFSKQNTIAIGYSLGTGVAVEMARKNLVSKMILFAPYTSIPDVASYRYVPIL 180 INFVQKNFSFSKQNTIAIGYSLGTGVAVEMARKNLVSKMILFAPYTSIPDVASYRYVPIL 180

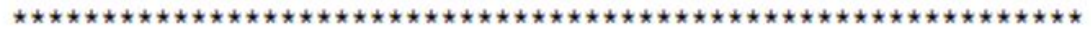

PQILIWDRFNSISKSKDLILPVLIIHGKKDVAVPYYMGETLNKSFSNAKLITLFNANHSL 240 PQILIWDRFNSISKSKDLILPVLIIHGKKDVAVPYYMGETLNKSFSNAKLITLFNANHSL 240

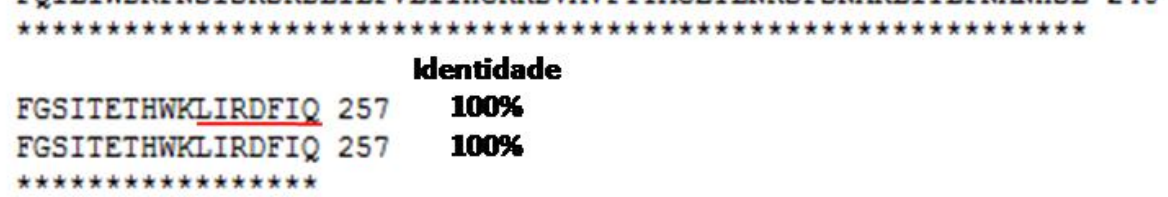




\section{UC10995}

L.i.Copenhageni

L.b.Hardjo-bovis_L550

L.i.Lai

L.i.Copenhageni

L.b.Hardjo-bovis_L550

L.i.Lai

L.i.Copenhageni

L.b.Hardjo-bovis_L550

L.i.Lai

L.i.Copenhageni

L.b.Hardjo-bovis_L550

L.i.Lai

L.i.Copenhageni

L.b.Hardjo-bovis_L550

L.i.Lai

L.i. Copenhageni

L.b.Hardjo-bovis_L550

L.i.Lai

L.i. Copenhageni

L.b.Hardjo-bovis_L550

L.i.Lai

L.i.Copenhageni

L.b.Hardjo-bovis_L550

L.i.Lai
MKIQLGIQN---RFRKVGLTLCFLIFLFGVNSINASYAKEILTYDLIGRN 47 MKIGLGIQKVQSRFRRIVLVVSFLVFLSGVNSISAAYEREILTYNLVGRG 50 MIREWNQSSVRFMIRRIGITFGVAIVLFVTQSISAAYERTVLTYEVIGRN 50

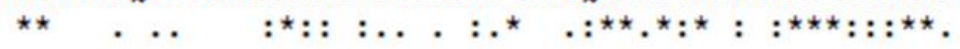

FY-SLKTTYYTINVVHYKYVRDPGSPIIFKPRSVLFVHGFGDNSTLFEPL 96 YN-SLETTYYKIDVVHYR--KPSGGPIIINPKAVLLVHGFGDNSAFFEPL 97 FYKNNETTNYRLNVIKYSLVQISPNPNLKN---VICIHGFGDNSTIYEPL 97

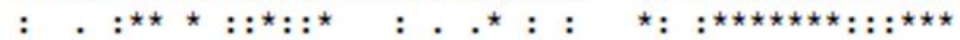

AKELILKGKAQNVYIMDLPGHGASTMAPGTSEYPANYSQLSVTNYADALR 146 AKELINQGKAAHVYIMDLPGHGASTMTRGTASVPANVSQLSVGNYGDALR 147 AKELINKGKARNVYILDLPGHGNSTVTQGSASLPKYASDLTLTHYSDALR 147

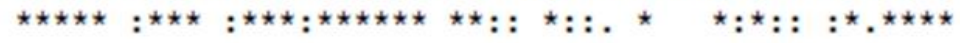

ALLGRMTSTEGKKIQTIVGHSTGGLVIQTIQDLFHRN--GGNLLSSFGIE 194 ALLSQMVDTEKRKITTIVGHSIGGLVIQMIQSKYRNE--NSSLLDAFGIE 195 ALLSQMTVTEGKRIHTIVGHSLGGIVIQLVQNQLVTRGWGGNLLASFGIE 197

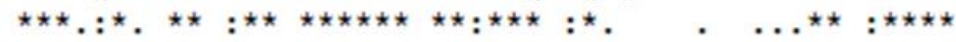

NTILLGSDIPSPLPWYGGDAPMSDPNSAKSFVWNFRILKILGSLPDPPYA 244 NTILIASDIPSALPWFGGDAPMSDPNSAKGFVWNFKTERVVEIQPFPPQV 245 NTILIASDIPSPLPWYPGDTDMNDPNSAKSLVWNFKVQKIVDSSPLYPYL 247

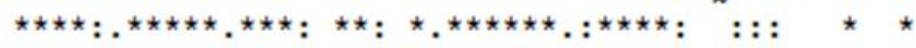

EFGWFVKTPDDFYINTKYAVNGVPVTGAPTTEQLKTMSDLEPYVAAANIV 294 IMGLFVETPDDFYINTKFAVNGVPVTGAPTPAQLEIMTNLEPYKAAANIV 295 IFGYFVESPNDFFIGTKYSVNGVPVSGAPTASEIPLMNNLEPYPAGANVV 297

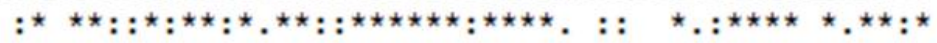

GLDYTAQTTDAVPRISVAQNLWNGFNLKVVWMDKDVFFSQSETQGLAQYL 344 GLDPSGQTTNAVSRLSVSPNIWNGFNLKVVWLEKGVFFSQSETQGLAQYL 345 GLDPSGETTESRPRLSVTQNIWNGFNLKVVWLDKDPFFSQSELQGLAQYL 347

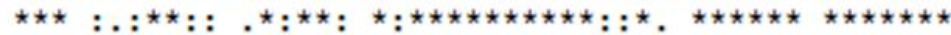

Identidade

KEGLNAITISDPEATHNSPFSKPSLFLSLF $374 \quad \mathbf{1 0 0} \%$ KTGLNAITISDPEAVHGAPFSKPSLFLSLF $375 \quad \mathbf{6 8 \%}$ KAGLDVITISDAEAVHGTPYSKPSLLVPLF $377 \quad \mathbf{5 9 \%}$ 


\section{ctligA}

L.b.Hardjo-bovis_JB197 L.b.Hardjo-bovis_L550 L.i.Lai

L.i.Copenhageni

L.b.Hardjo-bovis_JB197

L.b.Hardjo-bovis_L550

L.i.Lai

L.i.Copenhageni

L.b.Hardjo-bovis_JB197

L.b.Hardjo-bovis_L550

L.i.Lai

L.i.Copenhageni

L.b.Hardjo-bovis_JB197

L.b.Hardjo-bovis_L550

L.i.Lai

L.i.Copenhageni

L.b.Hardjo-bovis_JB197

L.b.Hardjo-bovis_L550

L.i.Lai

L.i.Copenhageni

L.b.Hardjo-bovis_JB197

L.b.Hardjo-bovis_L550

L.i.Lai

L.i.Copenhageni

L.b.Hardjo-bovis_JB197

L.b.Hardjo-bovis_L550

L.i.Lai

L.i.Copenhageni

L.b.Hardjo-bovis_JB197

L.b.Hardjo-bovis_L550

L.i.Lai

L.i.Copenhageni

L.b.Hardjo-bovis_JB197

L.b.Hardjo-bovis_L550

L.i.Lai

L.i.Copenhageni

L.b.Hardjo-bovis_JB197

L.b.Hardjo-bovis_L550

L.i.Lai

L.i.Copenhageni
-YKGEVRGEKIGITNIKAALGNVSSPIVALSVTEAELVSIQVSPYVSVTP 49 -YKGEVRGEKIGTTNIKAALGNVSSPIVALSVTEAELVSIQVSPYVSVTP 49 --QGNAYGAATGTTDIKATFGKVSSPVSTLSVTAAKLVEIQITPAAASKA 48 GYQGQAYGTGTGTVNIKATLGNVSSQVSKLSVTAAELTEIVLNPISSHKA 50

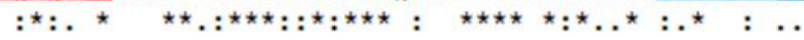

KGITKNFKATGTFTDYSTQDITEQVTWKSSDTEIISIENAAGNKGLAHML 99 KGITKNFKATGTFTDYSTQDITEQVTWKSSDTEIISIENAAGNKGLAHML 99 KGLTERFKATGIFTDNSNSDITNQVTWNSSNTDIAEIKNTSGSKGITNTL 98 KGLTENFKATGVFIDNSTKDITDQVIWKSSNAAYAKISNATGSKGVVNAL 100

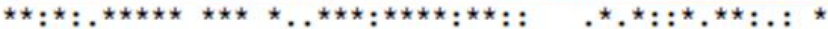

KQGDSYITATLGSISSSPELAMVVSPTIVSVAVTPSNPSVVKGLTCQFKA 149 KQGDSYITATLGSISSSPELAMVASPTIVSVAVTPSNPSVVKGLTCQFKA 149 TPGSSEISAALGSIKSSKVILKVTPAQLISIAVTPINPSVAKGLIRQFKA 148 SKGISHISATLGSISSANATFQVTPARIASIEVIPNNFFLIKGLSHPFKA 150

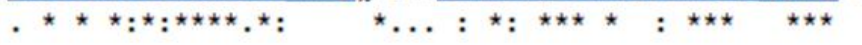

TATYTDNSTADITSMVSWSSSNSNKALVGNDILSGGLVTAVATGSANITA 199 TATYTDNSTADITSMVSWSSSNSNKALVGNDILSGGLVTAVATGSANITA 199 TGTYTDHSVQDVIALATWSSSNPGKAMVNN---VIGSVTTVATGNTNIKA 195 IGIYTDNTKIDITKOVSWSSSDPNVASIDNTFSLAGSATAIDDGKTNITA 200 $.{ }^{\star \star \star}::{ }^{\star}:{ }^{\star} \quad .:^{\star \star \star \star}: .{ }^{\star}: .^{\star} \quad{ }^{\star} .{ }^{\star}::{ }^{\star} .:^{\star \star} .^{\star}$

RY-ENLSGSSAVNVTPATLTSIEVTPVFPSVAKGLTEQFTATGIYSDKST 248 RY-ENLSGSSAVNVTPATLTSIEVTPVFPSVAKGLTEQFTATGIYSDKST 248 TI-DSISGSSVLNVTPALLTSIEITPTINSITHGLTKQFKATGIFSDKST 244 ILSDSMSASTILYVTSAVLIDIEVKPSIFVLSEGLTLQLTATGIYSDHST 250 $::^{\star} .^{\star}: .::^{\star \star},{ }^{\star} .^{\star \star}: .^{\star}::: .^{\star \star \star}{ }^{\star}: .^{\star \star \star \star}::^{\star \star}:{ }^{\star \star}$

QDLTQVVTWISSDSSRVAIENTAGKKGLALASTLGSSNIRATYNSIQSSP 298 QDLTQVVTWISSDSSRVAIENTAGKKGLALASTLGSSNIRATYNSIQSSP 298 QNLTQLVTWISSDPSKIEIENTSGKKGIATASKLGSSNIKAVYKFVQSSP 294 HDLIQVVQWISSKPSNIAIENTAGKKGKVIALAFGDSEFTATYDSIKSNR 300 $:: \star \star \star:{ }^{\star}{ }^{\star \star} .{ }^{\star} .::^{\star \star \star \star}::^{\star \star \star \star} .{ }^{\star} \quad:^{\star} \cdot{ }^{\star}::{ }^{\star},{ }^{\star} .::^{\star}$.

ISMTVTEAKLVSITVSPEFTSKALGLTQQFKAKGIFTDGSERDITNLVTW 348 ISMTVTEAKLVSITVSPEFTSKALGLTQQFKAKGIFTDGSERDITNLVTW 348 IPITVTDLKLKSITISPSSSSIAKGLTQQFKAIGTFIDGSEQEITNLVTW 344 AWIFVNDEKLVNITISSSQVLTDKGSAQQFKAIGIFOGGSQLDLTDLVTW 350

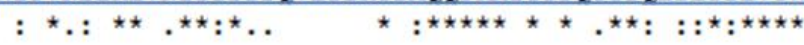

FSSEPLVADAINADENRGLAVSHSIGSTEIHAYYDSVESNSVNFKVTSSE 398 FSSEPLVADAINADENRGLAVSHSIGSTEIHAYYDSVESNSVNFKVTSSE 398 YSSKSDVAPINNAANAKGLATALSIGSSNISAIYNSISSNKINFNVSAAT 394 KSSDSKVVSISNSNDDRGLITALSVGSSKISAIYGSIHSDSIDFEVTPEI 400 ${ }^{\star \star} . .{ }^{\star} . \quad{ }^{\star}::::^{\star \star}: .:{ }^{\star}:{ }^{\star \star}::{ }^{\star} \star^{\star},{ }^{\star}:{ }^{\star}: .::^{\star}:{ }^{\star}:$.

LVSIEISPENGDLIKGLNQQYTAFGVYSDGSLQDISNSVTWYSSNTSSVS 448 LVSIEISPENGDLIKGLNQQYTAFGVYSDGSLQDISNSVTWYSSNTSSVS 448 LDSIKINPVNNNIAKGLIQQYTALGVYSDSTIQDISDSVTWSSSNSSSIS 444

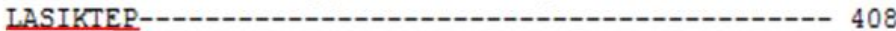
$\star \star \star: . *$

ISNAVGSKGKATALQVGTSKITATYRSVSGTTDLNVSAAILSSIVVSPTK 498 ISNAVGSKGKATALQVGTSKITATYRSVSGTTDLNVSAAILSSIVVSPTK 498 ISNSTETKGKATALQIGKSKITATYNSISENIDITVSAATLSSISISPIN 494

Os aminoácidos sublinhados em azul indicam domínios semelhantes à região repetitiva da família Lig. 


\section{LytM}

1 MKKLTAAAIATMGFATFTMAHQADAAETTNQQAHTQMSTQSQDVSYG 48

49 TYYTIDSNGDYHHTPDGNWNQAMFDNKEYSYTFVDAQGHKHYFYNCYP 96

97 KNANANGSGQTYVNQATAGDNNDYTASSQQHINQYGYQSNVGPDASY $\mathbf{1 4 4}$

145 YSHSNNNQAYNSHNGNGKVNYPNGTSNQNGGSASKATASGHAKDASWL 192

193 TSRKQLQPYGQYHGGGAHYGVDYAMPENSPVYSLTDGTVVQAGWSNYG 240

241 GGNQVTIKEANSNNYWYMHNRLTVSAGDKVKAGDQIAYSGSTGNST 288

289 APHVHFQRMSGGIGNQYAVDPTSYLQSR*

Os aminoácidos sublinhados em azul indicam o domínio semelhante à metaloprotease da família M23. 


\section{Anexo B}

Manuscrito: Failure of LIC13435 Protein of Leptospira interrogans Serovar Copenhageni to Confer Protection in Immunized Hamsters 